\title{
American-Australian Scientific Expedition to Arnhem Land (1948): Its Long-Range Impact
}

\author{
Raymond Louis Specht ${ }^{*}$
}

\begin{abstract}
Botanist, Ecologist, Ethno-botanist, American-Australian Scientific Expedition to Arnhem Land, Northern Territory,
\end{abstract} Australia

\begin{abstract}
The American-Australian Scientific Expedition to Arnhem Land in the Northern Territory of Australia was sponsored by the National Geographic Society and the Smithsonian Institution in the United States and the Commonwealth Government of Australia. During 1948, two anthropologists, an archaeologist, four biological scientists and three health and nutrition experts, with two photographers and three support staff, spent eight months studying the ecology of this infertile, monsoonal landscape to learn how the present-day Aborigines who had arrived between 3500 and 5000 years ago - displacing the first hunter-gatherers, the Mimi, who arrived some 53,000 to 60,000 years before - were able to survive throughout the year.

The Gondwanan origins of the heathy flora of the sandstones, the grassy eucalypt forests and woodlands on the lateritic earths, the monsoonal rainforests, the wetland and coastal plant communities -with vegetation structures similar to those in southern Australia - inspired long-term research on the physico-chemical processes (aerodynamic, water relations and mineral nutrition) that determine the structure, growth and biodiversity of plant formations throughout Australia.

The cooperative research that was fostered between the United States and Australia during the 1948 Arnhem Land Expedition has continued over the last sixty years in the Fulbright Program, the UNESCO Arid Zone Research Programme, the International Biological Programme (especially in the Arid Zone Biome, the Grassland Biome, the Mediterranean-climate Biome, the Heathland Biome, the Wet-Dry Tropical Biome and Rainforest Biome Programs), the International Union for the Conservation of Nature and, since the 1990s, the International Geosphere-Biosphere Programme to tackle Global Warming.
\end{abstract}

Keywords: Anthropology, archaeology, rock-art, hunter-gatherers, nutrition, biodiversity, ecosystem-research, Fulbright Program, International Biological Programme (IBP), IUCN, Global Warming (IGBP).

\section{THE AMERICAN-AUSTRALIAN SCIENTIFIC EXPEDITION TO ARNHEM LAND}

The National Geographic reporter/photographer, Howell Walker, was located in Darwin in 1941-42 (Walker 1942). He broke a limb and was sent south the day before the Japanese air raid on Darwin, February $19^{\text {th }} 1942$. Next year, as a member of the U.S. photogrammetric team, Howell photographed the reefs in the Coral Sea - in preparation for the battle that was to be the turning point in the Pacific War (Walker 1943).

During the 1920s and 1930s, Charles Percival Mountford, a P.M.G. (Post Master General's Department) Chief Mechanic had developed an intense interest in Aboriginal myths associated with rock engravings and paintings in Central Australia (Lamshed 1972). This selfeducated ethnologist accompanied five expeditions to study Aborigines in northern South Australia and the Northern Territory - the last three as leader who had to organise the trip and attend to all problems. Norman B. Tindale and C. P.

\footnotetext{
*Address correspondence to this author at the 107 Central Avenue, St Lucia, Queensland 4067, Australia; Tel: +61 73870 2240;

E-mail: r.specht@uqconnect.net
}

Mountford from the South Australian Museum and Professors of Anatomy (Frederic Wood Jones and successors), Pathology (John Burton Cleland), Dentistry (Thomas Draper Campbell), Zoological Parasitology (Thomas Harvey Johnston), Human Physiology (Cedric Stanton Hicks) - from the Board of Anthropological Studies (supported by the Rockefeller Foundation) in the University of Adelaide - were members of these expeditions. During this time, Mountford produced two colour films on Aboriginal life in the Centre 'Tjurunga' and 'Walkabout' - and a book entitled 'Brown Men and Red Sands' (Mountford 1948).

After the Second World War, the newly-formed Department of Information (under Minister Arthur Calwell) wished to foster relationships between Australia and the United States that had been initiated during the War in the Pacific. The Director-General of Information coopted Mountford to show his films on two lecture-tours in the U.S.A. as part of the overseas information program (1945 and 1946).

In Washington, D.C., the National Geographic (under the Director, Dr Gilbert Grosvenor) invited Monty to lead a small National Geographic Expedition to Arnhem Land (Fig. 1). The Expedition was to be financed by the accumulated profits from sales of the National Geographic Magazine in 


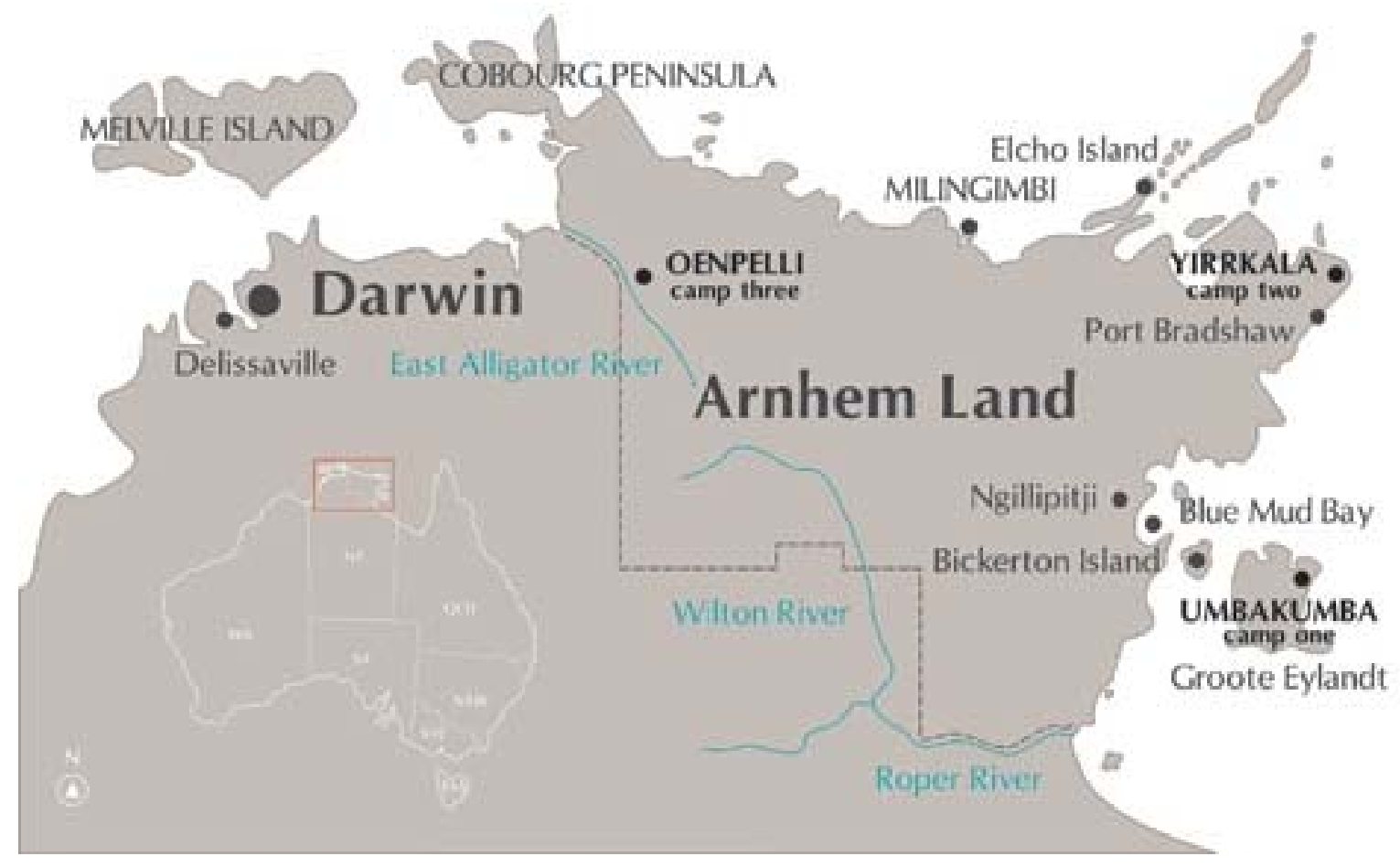

Fig. (1). Map of the 'Top End' of the Northern Territory of Australia, showing the Arnhem Land Aboriginal Reserve and the three camp sites of the American-Australian Scientific Expedition to Arnhem Land in 1948.

Australia - money that, just after the Second World War, could not be transferred back to the United States. Members of the Expedition were Mountford (leader, ethnologist), Howell Walker (National Geographic reporter), an archaeologist and a zoologist from the Smithsonian. In August 1946, Ray Specht of the Botany Department, University of Adelaide, was invited as botanist/ecologist without pay.

In January 1947, the Expedition of five specialists was postponed for a year to allow scientists from the Smithsonian Institution to survey the atoll of Bikini before the Hydrogen Bomb Test.

By 1948, the Expedition specialists had increased - from U.S.A., Frank Setzler archaeologist, Bert Deignan ornithologist, Dave Johnson mammals, Bob Miller fishes and reptiles, Howell Walker National Geographic reporter; from Australia, Mountford leader and ethnologist, Fred McCarthy anthropology, Ray Specht botanist/ecologist, Peter Bassett-Smith photographer; from the Australian Institute of Anatomy Brian Billington medic, Margaret McArthur nutritionist and Kelvin Hodges biochemist. A cook John Bray, later Reg Hollows, and transport officer Keith Cordon were appointed for logistic support. A Native Affairs Officer, Howard Coates, later Bill Harney, was appointed to liaise with the Aborigines. At the last moment, Mrs Bessie Mountford was appointed as chaperone for Margaret McArthur and to act as general secretary. Bessie Mountford and John Bray encouraged children to collect seashells, insects and lizards whenever possible.
Collecting equipment was provided by the Smithsonian Institution for their scientists (Frank Setzler, Bert Deignan, Bob Miller and Dave Johnson).

Photographic equipment for Howell Walker was provided by the National Geographic Society.

Equipment was provided by the Institute of Anatomy for the Health and Nutrition Unit (Brian Billington, Margaret McArthur and Kelvin Hodges).

Botanist-ecologist Ray Specht purchased all his own equipment - most by January 1947 in time for the small 1947 National Geographic Expedition that was deferred to enable Smithsonian scientists to survey Bikini Atoll before the hydrogen bomb was tested.

Peter Bassett-Smith provided his own equipment:

'Paill Bolex' movie camera (purchased in New York, 1946).

Pyrox wire recorder (purchased in Melbourne in 1946 before going to New York).

Two-way radio with 15 watt radio receiver \& morse code transmitter (Signals Unit, ex-Army).

Monty had never organised such a large team of specialists - but he encouraged all to do their separate research often in locations distant from base camp. However, it was a pity that he did not hold occasional inter-disciplinary discussions - similar to those being fostered by the C.S.I.R.O. Division of Land Research to define the land systems of Northern Australia (Christian \& Stewart 1953). 


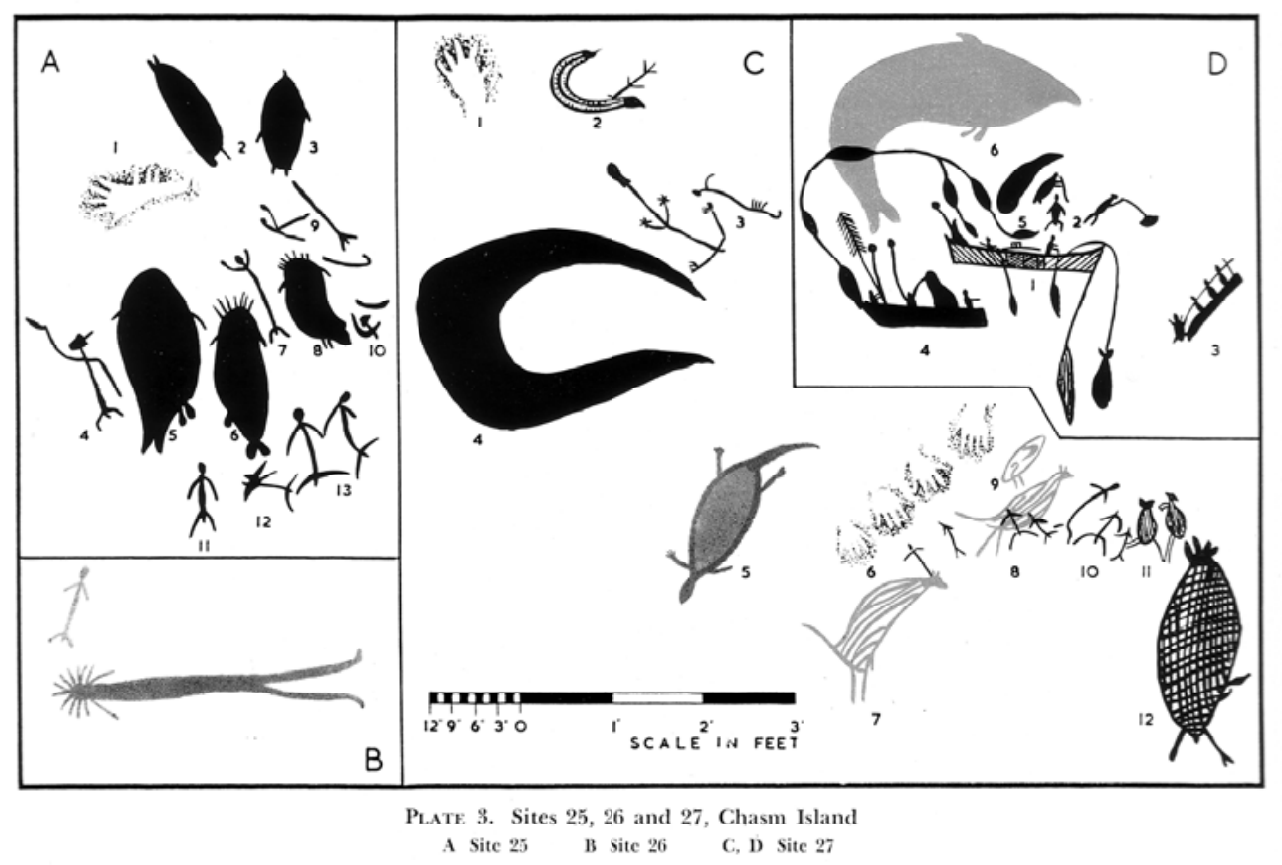

Fig. (2). Rock art recorded at Sites 25, 26 and 27 on Chasm Island (McCarthy 1960a).

His long experience in the Commonwealth Public Service, enabled him to 'pull strings' and manipulate the bureaucracy - much to the dismay of seniors in the Department of Information, who momentarily dismissed him during the first days at Yirrkala. Fortunately at this time, the Native Affairs Officer, Bill Harney, replaced Howard Coates who had proven a disaster in liaison with Aborigines and Expedition members on Groote Eylandt and Bickerton Island.

The broad aims of the biologists, anthropologists and nutritionist on the Expedition were: -

- To make a comprehensive collection of the plants and vertebrates (and molluses) on land and sea.

- To analyse the biogeographical relationships of the flora and fauna.

- To establish the ecological relationships of the flora and fauna.

- To investigate the origins of the first settlers (the Mimi Rock Art people).

- To investigate the hunter-gatherers who had displaced the Mimi settlers 3500 - 5000 years ago.

- To investigate the impact of the Macassan trepangers who visited over the previous 400 years.

- To analyse how hunter-gatherers had been able to live off the land for at least 50,000 years.

- To record the daily activities of men, women and children in hunter-gatherer societies.

- To record the plants used for food, implements, culture and the methods of construction and use.

- To assess the health (medical and dental) and nutrition of Aborigines in the settlements.
- To record the diversity of Rock Art on the sandstones of Arnhem Land.

- To record present-day art-styles and legends by Bark Painters of different language groups.

- To record dance and song rituals of different language groups, wherever possible.

Monty doggedly pursued his main interest - Aboriginal myth, art and symbolism - as well as organising the large team with their diverse interests, often well away from base camp. He sorted out many crises. It was a pity that Fred McCarthy's interest in the rock art of Chasm Island (recorded by Captain Matthew Flinders in 1803) trespassed on Monty's field - but Monty organised Fred's visit to Chasm Island (Fig. 2)!

Howell Walker, the National Geographic Society reporter and photographer on the Arnhem Land Expedition, wrote in a letter from Melville Bell Grosvenor to Mountford's biographer, Max Lamshed, on January $12^{\text {th }} 1971:-$

"I accepted the assignment with misgivings. It wasn't that I minded the thought of roughing it for eight or nine months in a pretty uncivilized and remote area of Australia; that adventurous aspect appealed to me. But this matter of living closely for so long a time with a dozen scientists - none of whom I knew - gave me pause. And what sort of expedition leader would Charles Mountford make?"

"If there was any question about his leadership, there was certainly no doubt about Monty's uncanny ability to staff his expedition with scientists of the highest calibre scientists who, incidentally, got along with each other like school kids on holiday. Generally, they stayed happy because Monty let each pursue his work in his own way, just as he let me alone to my writing and photography. It 
didn't take me long to realise that my misgivings about going on this expedition had been ill-founded."

"Charles Mountford inspired us with his devotion to his purpose: to document a Stone Age condition that had all but disappeared from the Australian scene. The proof of his success is embodied in the artefacts, articles, pictures, and scientific volumes resulting from the expedition that he led. The material he collected is irreplaceable history."

"For me, Mountford is to the Aborigines of Australia as Audubon was to birds of America."

\section{Publications}

National Geographic Magazine articles appeared before and after the American-Australian Scientific Expedition to Arnhem Land (Mountford 1946, 1949; Thomson 1948; Walker 1949) and even well after the Expedition (Johnson 1955, Carmichael 1960).

Mountford, CP (Jan. 1946) Earth's Most Primitive People. National Geographic Magazine, 89(1), 89-112.

Thomson, DF (March 1948) An Arnhem Land Adventure. National Geographic Magazine, 93(3), 403-30.

Walker, H (Sept. 1949) Cruise to Stone Age Arnhem Land, Australia. National Geographic Magazine, 96(3), 417-30.

Mountford, CP (with photographs by Howell Walker) (Dec. 1949) Exploring Stone Age Arnhem Land. National Geographic Magazine, 96(6), 745-82.

Johnson, DH (1955) The incredible kangaroo. National Geographic Magazine 108 (4), 487-500.

Carmichael, L (June 1960) The Smithsonian: Magnet on the Mall. National Geographic Magazine, 117(6), 796-845.

Mountford had a dream that five (later only four published) volumes of 'Records of the American-Australian Scientific Expedition to Arnhem Land' be collated, publication to be supported by the Department of Information.

However, the production of three films (with background music by Alfred and Mirrie Hill) that were taken by Peter Bassett-Smith, took priority - essential publicity for the Department of Information. In the United States, National Geographic Society reporter, Howell Walker, directed a film, 'The Arnhem Land Expedition', based on his own photography.

Aborigines of the Sea Coast (Yirrkala) - Director Charles P. Mountford; Camera Peter Bassett-Smith; Music Mirrie Hill.

Birds and Billabongs (Oenpelli) - Director Charles P. Mountford; Camera Peter Bassett-Smith; Music Mirrie Hill.

Arnhem Land - Director Charles P. Mountford; Camera Peter Bassett-Smith; Music Alfred F. Hill.

The Arnhem Land Expedition - Director and Camera Howell Walker, National Geographic Society.

Publication was further delayed when in 1954, the National Geographic Society asked Mountford to lead a second expedition to another little known part of Australia. Monty extended his study of Aboriginal art to the Tiwi culture on Melville Island, north of Darwin (Mountford 1958).
Manuscripts from Expedition members began to arrive on Monty's desk early in the 1950s where they were filed much to the dismay of the Expedition scientists. Eventually, Monty's dream of a four-volume publication by Melbourne University Press was financed by the Department of Information. The first volume on Art, Myth and Symbolism appeared in 1956; the third volume in the series Botany and Plant Ecology in 1958; Vol. 2 on Anthropology and Nutrition was published in 1960; the Fourth Volume on Zoology in 1964 (Mountford 1956; Specht \& Mountford 1958; Mountford 1960; Specht 1964). The Proof-Reader of Melbourne University Press, Barbara Ramsden, meticulously prepared the books for publication ${ }^{1}$.

The editing of the delayed Volume 4 Zoology was also undertaken by Ray and Marion Specht in their 'spare time'. As the Expedition ichthyologist, Bob Miller, left the Smithsonian Institution for an appointment at Ann Arbor University, Michigan, shortly after the end of the Expedition, the publication of all the other zoological articles in Volume 4 had to await the completion of identification of the fish collection by another Smithsonian scientist (Taylor 1964). However, the description of seven new species and seven new sub-species of reptiles, birds and mammals collected on the Arnhem Land Expedition appeared in the 1950s (Deignan 1950, 1951; Johnson 1954, 1959; Mitchell 1955). Publication of Vol. 4 was further delayed until 1964 by the absence overseas of Monty from Australia in the University of Cambridge. The collection of fauna, made by the mammalogist, Dave Johnson, on his epic twelve-day trek alone from Cape Don on the Coburg Peninsula to Oenpelli (now Gunbalanya), was expanded (1961 to 1968) in a fauna survey (mammals, birds, frogs and reptiles, also marine molluscs) of the Port Essington district by CSIRO Wildlife Research scientists (Frith \& Calaby 1974; Fisher \& Calaby 2009).

Mountford, CP (Ed) (1956) Records of the AmericanAustralian Scientific Expedition to Arnhem Land. Vol. 1. Art, Myth and Symbolism. Melbourne University Press, Melbourne.

Mountford, CP (Ed) (1960) Records of the AmericanAustralian Scientific Expedition to Arnhem Land. Vol. 2. Anthropology and Nutrition. Melbourne University Press, Melbourne.

Specht, RL \& Mountford, CP (Eds) (1958) Records of the American-Australian Scientific Expedition to Arnhem Land. Vol. 3. Botany and Plant Ecology. Melbourne University Press, Melbourne.

Specht, RL (Ed.) (1964) Records of the AmericanAustralian Scientific Expedition to arnhem land. Vol. 4. Zoology. Melbourne University Press, Melbourne.

The four Arnhem Land volumes (Appendix A) soon became collectors' items that few anthropologists or scientists could afford. Thus, vital information was often ignored by specialists who tend to search journal articles, not chapters buried in rare books.

Reunions of Arnhem Land Expedition members were organised by Ray Specht and Brian Billington in Sydney in

${ }^{1}$ Forty years before the development of word-processing on lap-top computers, the preparation of manuscripts and the indexing of books was a much more arduous task. 
1973 and 1998. A Song Book of bush-ballads that were composed and sung at the monthly dinners during the Expedition was collated by Ray Specht (1973a) for the $25^{\text {th }}$ Reunion; Personal Experiences on the Arnhem Land Expedition was collated by Ray and Alison Specht for the $50^{\text {th }}$ Reunion (Specht \& Specht 1998).

$25^{\text {th }}$ Arnhem Land Expedition Reunion (Sydney 10-11 $1^{\text {th }}$ March 1973): - Attended by Charles Mountford (leader and ethnologist), Bessie Mountford (secretary), Fred McCarthy (anthropologist), Brian Billington (doctor), Margaret McArthur (nutritionist), Kelvin Hodges (biochemist), Ray Specht (plant ecologist), Peter Bassett-Smith (cine photographer), Major Walter Murphy (Australian Defence Forces), Eric Jolliffe (PIX cartoonist) and their families.

$50^{\text {th }}$ Arnhem Land Expedition Reunion (Sydney, 27-28 ${ }^{\text {th }}$ June 1998): - Attended by Howell Walker (National Geographic Society reporter and photographer), Peter Bassett-Smith (cine photographer), Brian Billington (doctor), Bob Miller (ichthyologist), Ray Specht (plant ecologist), Stuart James (CMS agricultural advisor), Dorita and Elaine Thomson (daughters of anthropologist Donald Thomson), Velma Leeding (linguist from Umbakumba), with contributions from John Cawte (Aboriginal medicine, Elcho Island), Max Finlayson (Environmental Research Institute, Jabiru), Kelvin Hodges (biochemist), Carol Lentfer (teacher, Umbakumba) (Bassett-Smith 1998a, 1998b; Billington 1998; Cawte 1998; Finlayson et al. 1998a, 1998b; James 1998; Leeding 1998; Lenfer 1998; Miller 1998; Specht 1998a, 1998b; Thomson D 1998; Walker 1998).

During 2006-2008, historian Dr Martin Thomas explored the history of the 1948 Arnhem Land Expedition with surviving members, Ray Specht (St Lucia, Queensland), Peter Bassett-Smith (Kangaroo Ground, Victoria) and Gerald (Gerry) Blitner (Darwin, Northern Territory). Extensive research was undertaken in the archives of the Smithsonian Institution and the National Geographic Society in Washington, D.C., United States; in the ABC archives for the recordings of Colin Simpson and Ray Giles in Sydney, New South Wales and Charles Mountford's archives in the South Australian State Library. Martin published 'A short history of the 1948 Arnhem Land Expedition' in Aboriginal History (Thomas 2010).

An International Symposium to celebrate the Arnhem Land Expedition was held in the National Museum of Australia, Canberra, during 16-20 November 2009 and published in 2011 (Appendix B).

Neale, M (Project Director) (2009) 'Barks, Birds and Billabongs. Exploring the Legacy of the 1948 AmericanAustralian Scientific Expedition to Arnhem Land. International Symposium, National Museum of Australia, Canberra, 16-20 November 2009.

Thomas, M \& Neale, M (Eds) (2011) Exploring the Legacy of the 1948 Arnhem Land Expedition. Australian National University E Press, Canberra.

\section{Art, Myth and Symbolism}

The study of Aboriginal Art, Myth and Symbolism was the raison d'etre of the National Geographic Expedition to Arnhem Land. Mountford encouraged Aboriginal elders to depict their legends on sheets of stringybark (Eucalyptus
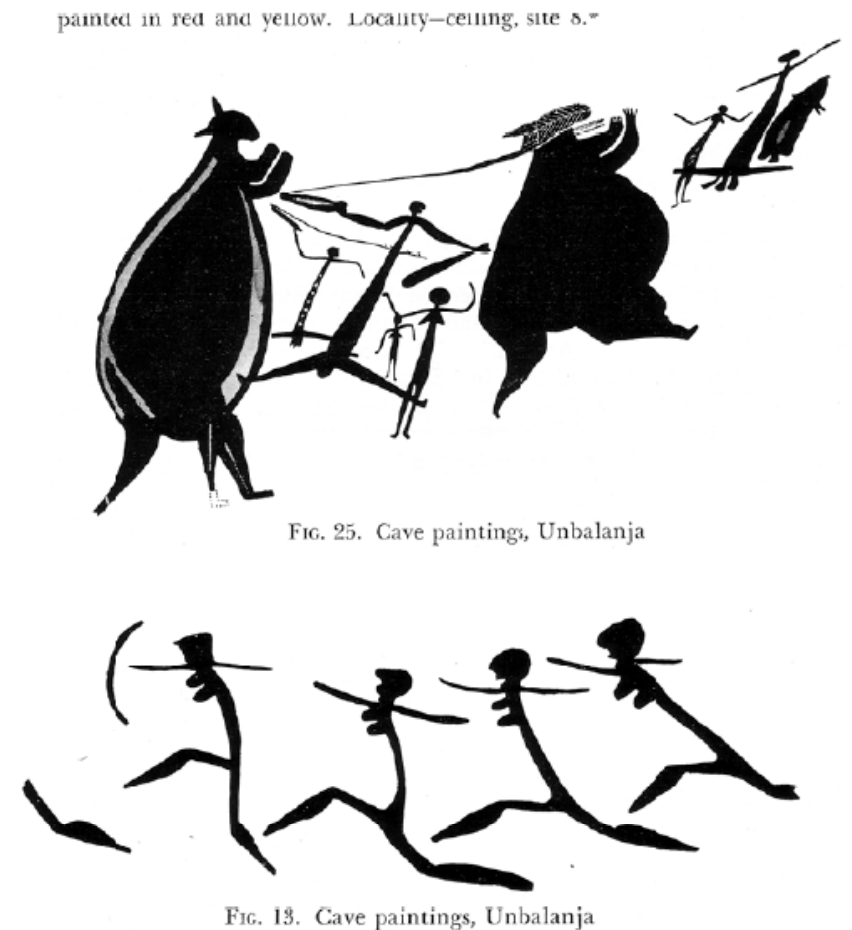

Fig. (3). Mimi rock art recorded at Unbalanja (Mountford 1956).

tetrodonta) or, if bark was not available, on sheets of drawing paper; the legend associated with each painting was then painstakingly expounded to Mountford (who wore a hearing aid) in broken English (Mountford 1956). The main artists - Nangapiana on Groote Eylandt, Mauwulan at Yirrkala, Kumutun at Oenpelli-were very tolerant and pleased to explain their art. Nevertheless because of Monty's poor hearing, it is possible that he misinterpreted some of the legends and interpolated his own pre-conceptions - a difficulty that Professor Baldwin Spencer pointed out to Norman Tindale when he visited the Professor in Melbourne before his studies on Groote Eylandt in the 1920s (Tindale 1925-26, pers. comm. 1980). ${ }^{2}$

Rock art on the Arnhem Land Escarpment at Oenpelli was composed of two major art forms - the ancient StickFigure Art that was believed to have been drawn by mythical beings, the Mimi; and the X-ray Art that depicted vertebrae and some internal organs of kangaroos, fish, etc. (Figs. 3 and 4). This latter art-form was no longer part of the local Oenpelli Aborigines; these artists had apparently left the area at the turn of the $20^{\text {th }}$ Century for the Tin Mines to the south. Mountford considered that the animated Mimi drawings of men in battle, hunting kangaroo, and running women (all with swollen buttocks) reminded him of the Bushmen Paintings in the Kalahari Desert of southern Africa. Mountford's hunch may be supported by the 'Out-ofAfrica's Eden' hypothesis (Oppenheimer 2003) that indigenous people from the south coast of South Africa (Marean et al. 2007) could have easily walked around the coastline to Indonesia and possibly to Australia when the sea-shore fell during an Ice-Age, 73,000 years ago.

\footnotetext{
${ }^{2}$ After the Expedition, Mauwulan taught his painting techniques to his daughters of the Marika Clan, thus establishing a flourishing commercial enterprise (Marika Heritage film, Australian Broadcasting Corporation, January 2004).
} 


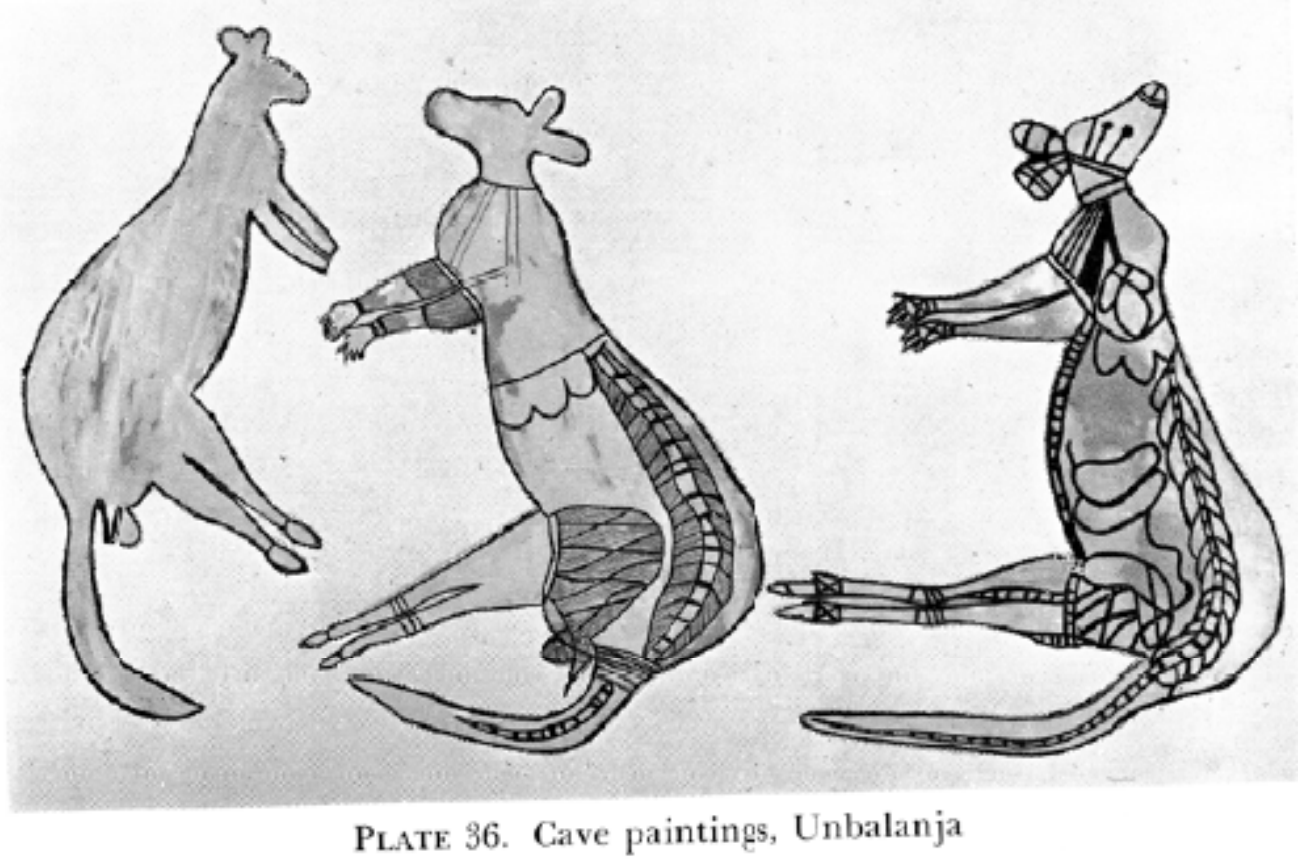

Fig. (4). Xray rock art at Unbalanja (Mountford 1956).

The rock art and the collection of bark paintings from Arnhem Land formed the basis for Mountford's contributions in the UNESCO World Art Series No. 3 (Mountford 1954) and in Volume 1 of Records of the American-Australian Scientific Expedition to Arnhem Land (Mountford 1956). The Mimi Running Women rock art (Fig. 3) was used as the logo for the Olympic Games in Melbourne in 1956.

After Volume 1 of the Arnhem Land Expedition was published in 1956, Mountford's collection of 171 bark paintings (91 from Groote Eylandt, 20 from Yirrkala, 34 from Oenpelli, 23 from Milingimbi, plus 3 others) and 104 paintings on sheets of drawing paper were assembled in Brisbane. In August of that year, the collection was shared between the six major Art Galleries in Australia (Julie Ewington and Diane Moon, Queensland Art Gallery, pers. comm. 2006).

In 1988, Brandl extended Mountford's study on rock art into Central Arnhem Land.

In 2000, Sally May used this material for her Honours research in Flinders University, South Australia - research that she expanded to foster community spirit amongst the indigenous Aborigines by the development of an art centre (May 2000, 2005, 2009).

Secret tribal ceremonies were recorded on film and wirerecorder at Bartalumba Bay, Groote Eylandt (by Mountford, Peter Bassett-Smith, Fred McCarthy and Frank Setzler) and near Oenpelli (where the Australian Broadcasting Commission reporter, Colin Simpson, and Ray Giles with the most up-to-date A.B.C. wire-recorders, joined the Expedition team).

In 2007, historian Dr Martin Thomas down-loaded the material on these 1948 tapes. The impact of this material, now almost forgotten by senior Aborigines in western Arnhem Land, was broadcasted on A.B.C. 'Radio Eye' program under the title 'Return to Arnhem Land' on June $2^{\text {nd }}$ 2007 and in an article entitled 'Taking Them Back. Archival Media in Arnhem Land Today' in Cultural Studies Review (Thomas 2007).

This contact with Aborigines inspired Colin Simpson to write his first book in the series on the development of tribal culture in 'primitive man' - 'Adam in Ochre' (Simpson 1951). Shortly afterwards, Peter Worsley, an anthropologist from Britain, investigated 'material symbols' and 'totemism' amongst the Aborigines of Groote Eylandt (Worsley 1954, 1955a).

Tribal dances and songs were accompanied by clapsticks, the didgeridoo (drone-tube), and a large drum-log (balnuknuk), made from hollow stems of the Darwin stringybark (Eucalyptus tetrodonta), a tree that dominates the open-forest across Northern Australia. Fifty years after the Arnhem Land Expedition, every tribal group within Australia seems to have adopted the didgeridoo of the Top End Aborigines as their own musical instrument.

The anthropologist, Fred McCarthy, from the Australian Museum, Sydney, had to play second-fiddle to Mountford. However, Fred made many valuable studies whenever the opportunity offered - rock art on Chasm Island that had been first observed by Captain Matthew Flinders in January 1803 (McCarthy 1960a); almost 200 string figures that the young Yirrkalan girl Narau could execute (McCarthy 1960b); the 'Snake Woman Story' of Hemple Bay, Groote Eylandt (published over 50 years later by Specht \& McCarthy 2005). As Fred had previously been largely concerned with the rock engravings on the Hawkesbury Sandstone near Sydney, the Arnhem Land Expedition was his first real contact with Aborigines. He studied hunting techniques by Aboriginal men while Margaret McArthur pursued her time-and-motion studies of food-gathering (by the women) at Hemple Bay and again at Fish Creek, near Oenpelli (see below). He studied the employment of Aboriginal men in buffalo 
hunting at the Oenpelli Mission (McCarthy 1954). He assisted the archaeologist Frank Setzler in digs on Macassan sites in coastal camps on the western side of the Gulf of Carpentaria and in Aboriginal cave-shelters near Oenpelli (see below). These experiences stirred Fred to produce 'Australia's Aborigines. Their Life and Culture' (McCarthy 1957) and to be appointed the first Director of the Australian Institute of Aboriginal Studies (AIAS).

Frank Setzler was particularly interested in the racial origins of the Arnhem Land Aborigines. He made measurements and plaster casts of Aboriginal skulls (physical anthropology).He found that, apart from the colour, the hair of the Arnhem Land Aborigines is similar to the hair of Caucasoids (Trotter et al. 1960); the high whorl frequency of palmar dermatoglyphs, however, showed relationships with Chinese and Inner Mongolians (Cummins \& Setzler 1960). Genetic evidence indicated that, "with the exception of New Guineans and their Melanesian relatives, Australian Aborigines have no close affinities with outside groups" (Kirk 1981). "The existence of at least two genetic marker traits in both black African and Aboriginal and Melanesian populations is intriguing" (Kirk 1981). It would be fascinating to see whether the observations of Setzler and Kirk are supported by DNA evidence.

The Aboriginal people of Groote Eylandt suffer from an unusual disease complex that has neurological, psychiatric and teratological features (Cawte 1984, 1985). Initially, it was thought that the disease could have been due to manganese toxicity from dust blown from the mining dumps deposited by the Groote Eylandt Mining Company (Gemco). However, this hypothesis was not proven; instead, a most unusual neurological ethnic-geographic ('genetic') isolate was recorded - only previously recorded in a group of people in Chile, also near a manganese mine (Kiloh \& Cawte 1987; Cawte 1990).

The cartoonist Eric Jolliffe paid a visit to the Expedition camp at Yirrkala to prepare a special spread of 'scientists-inaction' amongst sceptical Aborigines for the weekly magazine PIX (Jolliffe 1948).

\section{Archaeology}

Frank Setzler, archaeologist from the Smithsonian Institution, and Fred McCarthy, anthropologist from the Australian Museum, Sydney, collaborated in an attempt to determine the origin, or at least some of the prehistory, of the Aborigines in Arnhem Land. The impact of Macassan fishermen on Aboriginal life between the seventeenth and the nineteenth centuries was also an archaeological challenge. Digs were made at Macassan camps on Winchelsea Island and at Thompson Bay in Port Langdon, Groote Eylandt; in Port Bradshaw, north-east Arnhem Land; on Milingimbi Island; and surface middens in Melville Bay (McCarthy \& Setzler 1960). Later, Peter Worsley wrote a paper on early Asian contacts with northern Australia (Worsley 1955b), while Macknight and Thorne (1968) made two further digs at Macassan camp-sites; the impact of Macassan trepangers was summarised by Macknight (1976).

At Oenpelli, excavations were made in caves in the Arnhem Land Escarpment (McCarthy \& Setzler 1960). The relative paucity of artefacts in most of the sites made information on prehistory almost impossible. Many stone flakes were found, the most exciting find being a mounted elouera flake - the first hafted adze found in Australia (Setzler \& McCarthy 1950; McCarthy \& Setzler 1960, p. 269).

In the mid 1960s, archaeologist Carmel White excavated five rock shelters in western Arnhem Land, three sites on the plain and two in the hilly plateau (White 1967a). Early stone axes - blades and points, flake, ground, knapped and scrapers - were recorded from the sites (White 1967b). Analysis of the excavations were summarised in articles on the prehistory of the Kakadu people (White 1967c, 1969).

Later, archaeologists, using thermo-luminescence-dating techniques, have gained some idea of when the first Aborigines arrived in Northern Australia. Dating of quartzitic sediments from a rock shelter in Deaf Adder Gorge, north-west Northern Territory, indicated that Aborigines were present in Australia between 53,000 and 60,000 years ago (Roberts et al. 1990, 1994a, 1994b, 1998). Between 3,500 and 5,000 years ago during the last Ice Age (Chappell 1982), a distinct change in Aboriginal culture, apparently associated with the arrival of new people, began in Northern Australia and then spread southward (David \& Chant 1995). The dingo was introduced into Australia by these new arrivals and apparently accounted for the extinction of the thylacines and the Tasmanian Devil (Sarcophilus harrisii) from many localities on mainland Australia (Archer 1981). The archaeological digs of Faulkner \& Clarke (2004) indicated that Aboriginal exploitation of marine resources on the Blane Peninsula in Blue Mud Bay had been relatively continuous from 3000 years ago to the present day.

Since the celebration of the $60^{\text {th }}$ Anniversary of the Arnhem Land Expedition in 2009, archaeologist, Dr Bruno David of Monash University, has been invited by the Jawoyn people to examine the age of the rock art decorating the sandstone walls and cave ceilings in their homeland (Collis 2012).

The handover (from the Smithsonian Institution to the Arnhem Land delegation - Donald Gumurdul, Alfred Nayinggul, Thomas Amagula, and Joaz Wurramara) of skeletal remains collected on the 1948 Arnhem Land Expedition (May et al. 2005) took place on $29^{\text {th }}$ July 2008 at the Australian Embassy in Washington D.C.

At least 33 individuals have been returned as part of this agreement including men, women and children from Groote Eylandt and West Arnhem Land (Red Lily Lagoon, Arguluk Hill, and Injalak Hill).

In 2010 a second repatriation occurred at the Cultural Resources Center of the Smithsonian Institution's National Museum of the American Indian. Victor Gumurdul, Thomas Amagula and Joe Gumbula received the last of the human remains collected in 1948 and took them home to their communities in Arnhem Land. The ceremony was attended by about 50 people including senior representatives of the Smithsonian Institution, Native American supporters and the Australian Ambassador to Washington, Kim Beazley. In 2011 the people of Oenpelli were the first of the Arnhem Land communities to put the repatriated remains to rest. They organized a large public ceremony that involved wrapping the bones in paperbark and interring them in the 
Table 1. Major Diseases Found During Medical Examinations (Billington 1960; Hodges 1960)

\begin{tabular}{|c|c|c|c|c|}
\hline Locality & Umbakumba & Angoroko & Yirrkala & Oenpelli \\
\hline \hline No. Examined & 87 & 144 & 184 & $43 \%$ \\
\hline Males in total (\%) & $48 \%$ & $49 \%$ & $57 \%$ & $4(184)$ \\
\hline Under 16 yrs (\%) & $52 \%$ & $51 \%$ & $22 \%(103)$ & $9(111)$ \\
\hline Leprosy (No.) & $0(87) *$ & $1(144)$ & $21 \%(184)$ & $7 \%(111)$ \\
\hline Tuberculosis & $?$ & $11.5 \%(78)$ & $5 \%(156)$ & $0 \%(96)$ \\
\hline Yaws & $9 \%(87)$ & $3 \%(111)$ & $33 \%(49)$ & $94 \%(85)$ \\
\hline Malaria & $6 \%(68)$ & $?$ & $0.40 \pm 0.16(116)$ & $0.09 \pm 0.10(70)$ \\
\hline Hookworm & $?$ & $0.37 \pm 0.13(118)$ & $53 \%(84)$ & $68 \%(50)$ \\
\hline Ascorbic acid\# (mg \%)
\end{tabular}

* Numbers (in brackets) of Aborigines examined

\# Ascorbic acid was recorded in 38 nomadic Aborigines - $0.30 \pm 0.12 \mathrm{mg} \%$.

Table 2. Food Consumption of Animal and Plant Foods Collected by Small Tribal Groups at Four Camp-Sites in Arnhem Land, Northern Territory

\begin{tabular}{|c|c|c|c|c|c|c|c|c|c|}
\hline \multirow{3}{*}{ Camp-Site } & \multirow{3}{*}{ Month } & \multirow{3}{*}{ No. Days } & \multicolumn{2}{|c|}{ No. People } & \multicolumn{5}{|c|}{ Food Gathered } \\
\hline & & & Adults & Children & \multirow{2}{*}{$\frac{\text { Animal }}{\left(\mathrm{kg}^{*}\right)}$} & \multirow{2}{*}{$\begin{array}{c}\text { Plant } \\
\left(\mathrm{kg}^{*}\right)\end{array}$} & Animal & + & Plant \\
\hline & & & & & & & \multicolumn{3}{|c|}{ kg* / Person / Day } \\
\hline Hemple Bay & May & 4 & 8 & 5 & 98 & 41 & 2.0 & + & 0.7 \\
\hline Bickerton Is. & June & 3 & 9 & 6 & 21 & 36 & 0.5 & + & 0.8 \\
\hline Pt Bradshaw & July & 4 & 9 & 11 & 88 & 42 & 1.1 & + & 0.6 \\
\hline Fish Creek & Oct. & 11 & 8 & 1 & 237 & 19 & 2.4 & + & 0.3 \\
\hline
\end{tabular}

* The bones, skin, etc. of the animals, the husks of yams, the pips of fruit, etc. were included in the weight.

$\dagger$ Between March 1948 and March 1949, Aborigines of the Umbakumba Settlement, Groote Eylandt, each consumed daily $450 \mathrm{~g}$ of cassava (Manihot esculenta), $200 \mathrm{~g}$ of sweet potatoes (Ipomoea batatus), $100 \mathrm{~g}$ of watermelon (Citrullus lanatus) and $100 \mathrm{~g}$ of other vegetables and fruit, all grown in the settlement garden (McArthur 1960a, p. 15). Turtle meat, turtle eggs and fish provided animal protein.

ground at the base of Argaluk hill, one of the sites from which they were taken (Martin Thomas, pers. comm. June 2012; The Age, Melbourne, 20 ${ }^{\text {th }}$ July 2011).

\section{HEALTH OF ABORIGINES IN ARNHEM LAND SETTLEMENTS (1948)}

The medical officer, Dr Brian Billington, examined the health of Aborigines resident in the settlements within the Arnhem Land Aboriginal Reserve (Billington 1960). Diseases such as leprosy, tuberculosis, yaws, malaria and hookworm infection were recorded (Table 1). Kelvin Hodges analysed blood samples for Plasma Ascorbic Acid (mg\%) and Haemoglobin (g\%) (Hodges 1960).

\section{ABORIGINAL NUTRITIONAL STRATEGIES}

Margaret McArthur's 'time-and-motion' studies (McArthur 1960a) on food gathering of nomadic Aborigines had never been attempted in Australia (possibly in the world).

Food consumption of groups of Aborigines living on naturally-occurring foods was studied at four camp-sites in Arnhem Land, Northern Territory (Table 2, after McArthur,
Records of the American Australian Scientific Expedition to Arnhem Land. Vol. 2, 1960a): -

(1) Hemple Bay (lat. $13^{\circ} 45^{\prime} \mathrm{S}$, long. $136^{\circ} 40^{\prime} \mathrm{E}$ ) on Groote Eylandt

animal foods: fish and turtle

plant foods: tubers of the waterlily (Nymphaea violacea) and roots of Ipomoea velutina.

\section{(2) Bickerton Island (lat. $13^{\circ} 45^{\prime} \mathrm{S}$, long. $136^{\circ} 10^{\prime} \mathrm{E}$ )}

animal foods: fish

plant foods: mostly roots of Ipomoea graminea and Vigna vexillata;

fruits of the bush grape (Cayratia trifolia).

(3) Port Bradshaw (lat. $12^{\circ} 29^{\prime} \mathrm{S}$, long. $136^{\circ} 45^{\prime} \mathrm{E}$ )

animal foods: fish and oysters

plant foods: mostly tubers of Dioscorea transversa (parsnip yam) and Curculigo ensifolia (grass potato).

(4) Fish Creek (lat. $12^{\circ} 15$ 'S, long. $133^{\circ} 15$ 'E) near Oenpelli

animal foods: fish and kangaroo 
Table 3. Mean Daily Consumption of Various Nutrients Per Head at Four Camp-Sites in Arnhem Land, Northern Territory

\begin{tabular}{|c|c|c|c|c|c|c|c|}
\hline \multirow{2}{*}{ Camp-Site } & \multirow{2}{*}{ Month } & \multirow{2}{*}{$\begin{array}{l}\text { Energy } \\
\text { (Joules) }\end{array}$} & \multicolumn{2}{|c|}{ Protein $(g)$} & \multirow{2}{*}{$\begin{array}{r}\text { Iron* } \\
(\mathrm{mg})\end{array}$} & \multirow{2}{*}{$\begin{array}{c}\text { Calcium } \\
\text { (g) }\end{array}$} & \multirow{2}{*}{$\begin{array}{l}\text { Ascorbic } \\
\text { Acid (mg) }\end{array}$} \\
\hline & & & Animal & Plant & & & \\
\hline Hemple Bay & May & 9040 & 205 & 27 & 12 & $>0.7$ & 224 \\
\hline Bickerton Is. & June & 4900 & 60 & 16 & 3 & 1.1 & 103 \\
\hline Pt Bradshaw & July & 5780 & 140 & 10 & 42 & $>1.1$ & 110 \\
\hline Fish Creek & Oct. & 8920 & 300 & 3 & 35 & 0.3 & 28 \\
\hline
\end{tabular}

*Iron from animal products only.

plant foods: a few yams (Dioscorea bulbifera)

some fruits of Syzygium suborbiculare (red apple).

The daily dietary value of the food consumed by each person in the four camp-sites in Arnhem Land, Northern Territory, was assessed (Table 3, McArthur 1960).

The food collected by the Aborigines at Hemple Bay and Fish Creek provided the recommended dietary allowance of energy and four times the recommended amount of animal protein per day. At Hemple Bay, ascorbic acid in plant foods was almost four times the recommended daily intake, whereas plant foods were almost absent from the daily diet at Fish Creek at the end of the 'Dry Season' (McArthur 1960).

Since 1948 there has been significant economic transformation throughout Western Arnhem Land, but Aboriginal people remain determined to engage in customary activity and to harvest wildlife for sustenance. There is growing evidence that engaging in the customary sector generates health and livelihood benefits. This evidence base, as in 1948, appears to have little impact on policy makers, who disregard other options. The current one-dimensional fantasy for the people of Western Arnhem Land is communities re-centralised in what are now called 'Territory Growth Towns'. It will be interesting to see how Aboriginal people engage with this new state project of improvement and what impacts this policy shift has on a customary sector that has remained relatively resilient in this region over the past 60 years. (Altman 2011, p. 134).

The fundamental work of the team from the Australian Institute of Anatomy was republished in the Asia Pacific Journal of Clinical Nutrition, Vol. 9 (McArthur et al. 2000a, 2000b) thanks to the Editor Prof. Mark Wahlqvist, one of Ray Specht's relations. The importance of biodiversity in foods was stressed (Wahlqvist \& Specht 1998). A survey of the teeth of Aborigines in Arnhem Land settlements made by John Moody, the 'Flying Dentist' of the Northern Territory Aerial Medical Service, was published in Volume 2 of the Records of the Expedition (Moody 1960, 1998); a plaster cast of a set of teeth, badly worn by grit in food cooked in an open fire, has been returned to Arnhem Land. Janice Reid studied 'Sorcery and Healing' in the Yolngu people for her Ph. D. (Reid 1983). Assessment of the mental health of Aborigines in many areas of Australia - especially on Elcho Island (Cawte 1996) - was made by Specht's secondary school-mate, psychiatrist John Cawte and associates (Specht et al. 2013). A chapter on 'Aboriginal Impact'was included in 'Australian Plant Communities. Dynamics of Structure, Growth and Biodiversity'(Specht \& Specht A. 1999, pp.
132-156). Obituaries of Margaret McArthur Oliver (19192002) and Brian Price Billington (1923-2004) were compiled by Ray Specht in 2002 and 2004 respectively.

How many nomadic Aborigines were able to survive off the land in Arnhem Land (or in other regions of Australia) will never be known (Meehan \& White 1990).

\section{The 'Flying Dentist', John E. H. Moody, July 1998}

"By the time the Arnhem Land Expedition arrived in the Northern Territory, I had visited a number of settlements and was beginning to arrive at some ideas. I heard about the Expedition and thought that the Nutrition Unit might have information of use to me. I asked the Medical Superintendant (who was in charge of 'Aerial Medical Services' and Darwin Hospital during the absence of the CMO) to sanction my visiting Yirrkala while the Expedition was there during July 1948. He was more co-operative than the $\mathrm{CMO}$ and saw potential value in the idea and so it was arranged."

"Brian Billington, the leader of the Nutrition Unit, realised that my findings re oral conditions were new and of value and we agreed that we did not want to steal each others findings. Brian invited me to contribute my findings to the Expedition. He consulted C. P. Mountford who readily sanctioned my inclusion. I was offered a bunk in the Expedition camp but, as the Fijian superintendant of the local mission had invited me to the mission house, I felt it could be a bit slighting to decline his offer. I thus missed out on contact with Expedition personnel apart from Brian Billington and Kelvin Hodges; Margaret McArthur was undertaking time-and-motion studies of hunter-gatherers at Port Bradshaw at the time."

"I wrote up my contribution before I left Darwin in December 1948. A copy was sent to the Australian Dental Journal where it appeared in its original form. By inclusion in the Expedition, I was motivated to take a more 'scientific' approach than I may have done otherwise. I made some revisions and additions before I left the N.T. 'The Dental and Periodontal Conditions of Aborigines at Settlements in Arnhem Land' was included in the 'Report of the Nutrition Unit', edited by Margaret McArthur in Volume 2, 'Anthropology and Nutrition' of 'Records of the American-Australian Scientific Expedition to Arnhem Land' (Ed. C. P. Mountford, Melbourne University Press, 1960)."

\section{ETHNOBOTANY}


The Arnhem Land Expedition provided an opportunity to assemble detailed information on the use of plants for food, medicine, implements and culture by Aborigines throughout the Arnhem Land Aboriginal Reserve (Specht 1958c). The names of plants used by Aborigines on Groote Eylandt, on Bickerton Island and at Yirrkala were recorded using the International Phonetic Alphabet (Specht 1958c, 2006); a bilingual Aborigine, Kumbiala, who was suspected of being involved in the spearing of two beachcombers on Woodah Island in 1933 (pers. comm. 1948 of Fred Gray of Umbakumba in Cole 1984; Dewar 1992; Egan 1996; McMillan 2001) provided invaluable information. These observations formed the first comprehensive survey made on ethno-botany in northern Australia since the publication of Dr Roth in 1897 or those of Professors J. B. Cleland and T. H. Johnson made in South and Central Australia during the 1930s (Cleland 1966). ${ }^{3}$

Specht's research stimulated several detailed studies on ethno-botany in Arnhem Land: - Groote Eylandt (Worsley 1961: Levitt 1981; Leeding 2006), Yirrkala (Yunupingu et al. 1995), Milingimbi (Wightman \& Smith 1989) and Oenpelli (Smyth \& von Sturmer 1981). Ethno-botanical studies were made in country similar to Arnhem Land on Cape York Peninsula in northern Queensland (Hynes \& Chase 1982; Specht \& Specht 1999, pp. 146-147).

It was unfortunate that Dr Brian Billington was so involved in the medical examinations of Aborigines in Arnhem Land settlements (Billington 1960) that little information on medicinal plants was obtained during the Expedition. In the late 1970s, Neville Scarlett (1982) studied 'Bush Medicines of the Yolngu'people. Dulcie Levitt (1981, pp. 52-67) recorded plants used on Groote Eylandt for the treatment of aches and pains, bites and stings, bleeding, boils, burns and sores, broken bones, childbirth, cicatrices, constipation, coughs and colds, diarrhoea, difficulties in passing urine, excitement, eyes, leprosy, madness, mother's milk, skin troubles, wounds. Yunupingu et al. (1995, pp. 100-101) have recorded plants used as medicine - for treating eye disorders, intestinal ailments, pain relief, respiratory ailments, and skin ailments. Emanuela Appetiti (2005) referred to these studies in a survey of information on 'Remedies from the Bush: Traditional Medicine among the Australian Aborigines'. The possible antibiotic action of the bracket fungus (Fomes spp.) in the healing of wounds (Specht 1958c) has never been investigated.

Peter Worsley (1961, p. 158, Appendix pp. 181-189) remarked that, although Groote Eylandt 'may appear barren to the undiscerning White man,' the island was remarkably rich in bush-products consumed by the natives.

Land-animals (including reptiles)

79 edible kinds

Birds (sea and land)

76 edible kinds

Marine animals (fish, dugong, stingray, dolphins)

98 edible kinds

Plants and trees 83 edible kinds

\footnotetext{
${ }^{3}$ An overview of the major plants and animals used seasonally by Arnhem Landers had been collated by Donald Thomson (1939, 1946, 1983, 2003, pp. 172-173) during his 'conciliatory missions' in 1935 and 1936.

In 1949, the Queensland Government Botanist, Cyril T. White, described some new plants in Donald Thomson's Arnhem Land collection (White 1949).
}

Crabs and shellfish

39 edible kinds

'Ordering space and time is a significant Groote Eylandt skill, the Enindilyakwa language exhibiting a rich vocabulary for this purpose. Groote Eylandters describe large-scale location in terms of clan territories, natural environments and specific place names. On a small scale, prepositions relate the position of an item to that of a second item. Individual Enindilyakwa words specify dimensions such as size, length and depth. In ordering time, Groote Eylandters utilise a variety of natural devices. Predictably, the passage of a day is marked by the sun's position. The passage of time in a year is marked by specific reference to prevailing winds, seasonal weather and recurrent biological phenomena.'

\section{(John Harris, Abstract p. iii, M.Sc. Thesis 1979)}

'The Warnimamalya are event-oriented whereas most Anglo-Australians are time-oriented. This became very apparent when I taught Enindilyakwa literacy to Aboriginal Teaching Assistants in 1975. The books for the early lessons could be completed in one and a half hours but from No. 7 were twice the size. I taught half the booklet and told the class it was time to go. Instead of leaving in their usual style, chatting and laughing, they moved out slowly and quietly. Next day, the booklet was completed and normal behaviour returned. In the middle of No. 8, I said that we would stop and there was silence. I asked, "What do you want to do?" and they chorused, "Finish the book!" I taught for three hours and they went home happily while I collapsed with a cup of coffee. And so began my understanding of what it means to be job-oriented. Because of the reactions in the literacy class, I learnt that once you start a task you see yourself as a failure unless you finish it within the expected time period (which can be very flexible).' ----- 'Pride and satisfaction for an Aboriginal comes from getting the job done successfully; pride and status for a non-Aboriginal employee is often linked with punctuality. This tension remains today in the work-a-day world but there is now a greater awareness of the cultural difference.'

(Regional Linguist for Bilingual Education, Velma Leeding 1998, p. 57)

The ethno-botanical studies of Roth (1897) formed the basis for a compilation of 'Friendly Foods and Vegetables' in Queensland that the Queensland Government Botanist, C. T. White, and D. A. Herbert, Head later Professor of Botany in the University of Queensland, collated for the Commander of Allied Land Forces, South West Pacific Area (1943) for living off the land in tropical Queensland during the Second World War. In the mid 1960s, Prof. Des Herbert was urged to publish this manuscript by his successor Prof. Ray Specht. Instead, he encouraged his daughter Joan and husband Alan Cribb to compile 'Wild Food in Australia' (Cribb \& Cribb 1974) and 'Wild Medicine in Australia' (Cribb \& Cribb 1981); their publications incorporated the Arnhem Land Expedition material (Specht 1958c) and references included in the 'Bibliography of Food Plants of Australian Aborigines' collated by Dr F. R. Irvine (1957, unpubl. post 1958) of the Herbarium, Kew Botanic Gardens, England. Later, Jennifer Isaacs produced a coffee-table book on 'Bush 


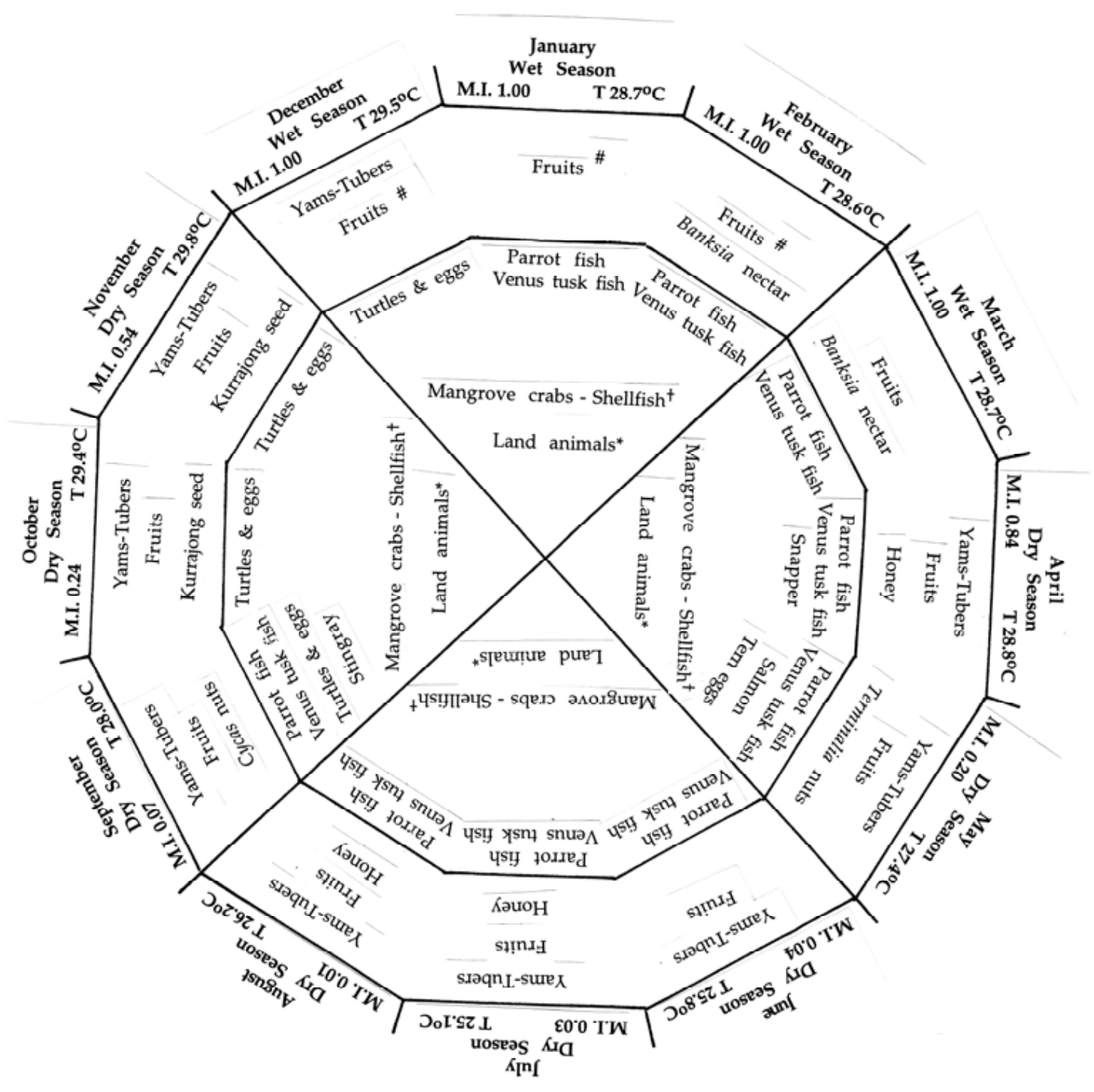

Fig. (5). Annual ecological cycle of food gathering in the monsoonal climate of Arnhem Land (after Specht \& Specht A 1999, Fig. 8.7).

Food' (Isaacs 1992); Prof. John Pearn presented a paper on 'Medical Ethnobotany of Australia. Past and Present' to the Linnean Society, London on $30^{\text {th }}$ September 2004; more recently, Philip Clarke compiled a book on 'Aboriginal People and their Plants' (Clarke 2007).

The presence of toxic ingredients in bush tucker was summarised in 'Food Safety of Australian Plant Bush Foods' (Hegarty et al. 2001).

The yearly cycle of food gathering in Arnhem Land is summarised in Fig. (5).

Macassan fishermen made annual visits to Arnhem Land to harvest trepang (bêche-de-mere, holothurians) some centuries before the explorer Captain Matthew Flinders arrived off the coast in 1803. They taught the Aborigines how to make dugout canoes with a Macassan sail (May et al. 2009). The dugout canoe provided greater safety in turtle and dugong fishing than the former bark canoe made from the fibrous bark of the Darwin Stringybark (Eucalyptus tetrodonta), a tree dominant in the open-forests of Northern
Australia (Specht 1958c). When the Expedition visited Yirrkala during July to August 1948, none amongst the Aborigines knew how to make a bark canoe. The Natives Affairs Officer, Bill Harney, instructed them in the technique to be filmed by Peter Bassett-Smith and Howell Walker for the film 'Birds and Billabongs'.

\section{BIOLOGICAL COLLECTIONS}

Almost no collections of the flora and fauna of terrestrial and marine ecosystems in the Arnhem Land Aboriginal Reserve, N.T., had been made since Captain Matthew Flinders, in the 'Investigator', explored the western side of the Gulf of Carpentaria during January to March 1803 (Specht 1958f; Specht, MM 1964).

In 1928, the explorer, Donald Mackay, accompanied by the talented geologist - medical doctor - anthropologist Herbert Basedow (Pearn 2001), traversed Arnhem Land from the Wilton River to Oenpelli via the Arafura Swamps. 
Table 4. Botanical and zoological collections of the American-Australian Scientific Expedition to Arnhem Land, Northern Territory (March - November 1948)

Table 4A. Flora (Bibby 1958; Catcheside 1958; Cunningham 1958; Dennis 1958; Scott \& Prescott 1958; Specht 1958g; Tindale 1958; Womersley 1958; Wood 1958). Stan Blake of Queensland Herbarium identified the grasses, sedges and eucalypts (Blake 1953; Specht 1958g)

\begin{tabular}{|l|c|c|c|c|}
\hline \multicolumn{1}{|c|}{ Plant group } & taxa & nov. spp. & nov. var. & nov. form. \\
\hline \hline Freshwater algae & 325 & 20 & 33 & - \\
\hline Charales & 5 & - & - & - \\
\hline Marine algae & 60 & - & - & - \\
\hline Basidiomycetes & 17 & - & - & - \\
\hline Agaricaceae & 5 & - & - & - \\
\hline Lichens* & 3 & - & - & - \\
\hline Bryophytes* & 3 & - & - & - \\
\hline Pteridophytes & 20 & - & - & - \\
\hline Cycads & 1 & - & - & - \\
\hline Cupressaceae & 1 & - & - & - \\
\hline Monocotyledons & 213 & - & 6 & - \\
\hline Dicotyledons & 522 & 15 & & - \\
\hline
\end{tabular}

*The lack of shade under trees from the almost vertical solar radiation in the tropics affects the survival of lichens and bryophytes (mosses and liverworts) in the open plant communities in Arnhem Land (Specht \& Mountford 1958; Rogers \&Stevens 1981; Specht \& Specht A 1999).

Table 4B. Fauna (Cotton 1964; Deignan 1950, 1951, 1964; Johnson 1954, 1959, 1964; Lachner \& Taylor 1960; Mitchell 1955, 1964; Taylor 1964) (Smithsonian Institution and the Adelaide Museum) Insects collected by John E. Bray were Deposited in Smithsonian Institution, Australian Museum, Sydney and the Adelaide Museum, Sydney (Specht, 1964, p. 309)

\begin{tabular}{|c|c|c|c|}
\hline Animal Group & taxa & nov. spp. & nov. sub-spp. \\
\hline \hline Insects & 39 & 2 & - \\
\hline Molluscs & 105 & 2 & - \\
\hline Fish & 246 & 5 & - \\
\hline Fish & +5 extra families & - & - \\
\hline Amphibians & 10 & - & - \\
\hline Reptiles & 53 & 2 & - \\
\hline Birds & $191+315$ Sighted & 4 & 2 \\
\hline Mammals & 57 & 3 & \\
\hline
\end{tabular}

Basedow collected 208 plant specimens on this expedition (Anon 1958). Three new species (not included in The Flora of the Northern Territory, published by Ewart \& Davies in 1917) were described by Kew botanists Pandanus basedowii from the top of the Arnhem Land sandstone escarpment was described by C. H. Wright in 1930, and two new grasses, Eriachne basedowii and E. filiformis, were described by W. Hartley in 1942.

The biologists of the Arnhem Land Expedition attempted to make comprehensive collections of flora and fauna at each of the localities where they were stationed (Table 4).

- The lack of shade under trees from the almost vertical solar radiation in the tropics affects the survival of lichens and bryophytes (mosses and liverworts) in the open plant communities in Arnhem Land (Specht \& Mountford 1958; Rogers $\&$ Stevens 1981; Specht \& Specht A 1999).
- Lists of the botanical and zoological taxa (with nomenclature updated) will be published as Appendices in a special issue ofThe Beagle, Records of the Museums and Art Galleries of the Northern Territoryin the near future.

\section{BIOGEOGRAPHY}

Three major plant formations are found in Arnhem Land (Specht 1958a): - (1) remnants of the tropical rainforest vegetation (Webb et al. 1984; Russell-Smith 1991), (2) an open-forest to woodland with a grassy (savanna) understorey, and (3) the sandstone flora. Freshwater wetlands, coastal wetlands and coastal dunes are interlaced.

The sandstone flora of the western Kimberley region was collected by the Government Botanist of Victoria, Ferdinand von Mueller, on A. C. Gregory's North Australian Expedition to find Ludwig Leichhardt in 1855-56. From his deep knowledge of the flora of India, Hooker (1860) recognised that there was a strong floristic affinity with the 


\section{Sandstone flora}

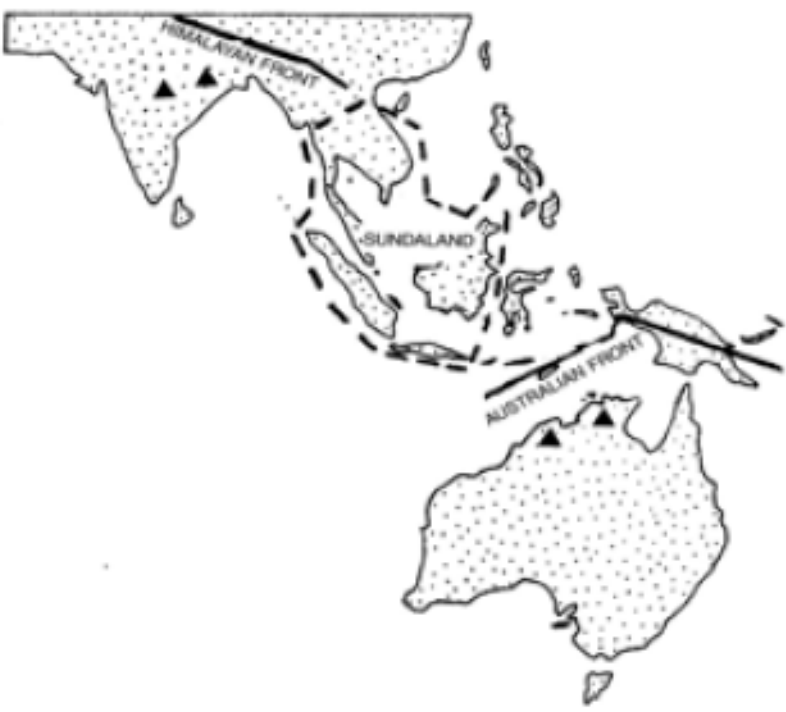

Fig. (6). Some $14 \%$ of the flora that has been recorded on the sandstone outcrops of northern Australia has also been found in the sandstone hills of eastern India (after Specht \& Specht 1999, Fig. 5.8).

vegetation in India - over 500 species belonging to 273 genera. The Gondwanan flora of monsoonal Australia still contains $26 \%$ of the species - not just the genera, as noted by Hooker (1860) - in common with the Indian Peninsula (Specht 1958b). Some plant formations include even higher percentages: - monsoon rainforests (35\% of the species), coastal wetlands $(62 \%)$, coastal dunes $(26 \%)$, freshwater wetlands $(32 \%)$, eucalypt open-forests $(17 \%)$, sandstone complex (14\%). The distribution of many of these species extends to tropical Africa (Specht 1958b): - monsoon rainforests $(15 \%)$, coastal wetlands $(31 \%)$, coastal dunes (16\%), wetlands $(16 \%)$, eucalypt open-forest $(9 \%)$, sandstone complex $(7 \%)$.

As many species of the wetland and coastal vegetation (including monsoonal rainforest vegetation on coastal dunes) are very mobile, they may be distributed continuously on the shoreline between Northern Australia and India - the IndoMalayan flora (Diels 1906: Burbidge 1960). 'The sandstone tableland presents an arid, cheerless landscape, described by Dr Mueller in terms that apply perfectly well to the sandstone tablelands of the peninsula of India, and indeed many of the characteristic genera are common to both' (Hooker 1860, p. xl). Most of the genera (and many of the species) in the herbaceous flora of the sandstone tablelands of the western Peninsula of India and Northern Australia have been recorded in the Malayan Peninsula and Indonesian Islands (Specht 1958b); these floras have been present since the break-up of Gondwanaland in the Late Cretaceous (Fig. (6), after Specht 1958b, 1988a; Specht \& Specht A. 1999).

The ancient lateritic earths that cover northern Australia from Cape York Peninsula in Queensland (Specht et al. 1977), across the Top End of the Northern Territory (Specht 1958a, 1958b) into north-west Western Australia (Specht 1981a), were formed - from Australia, across India and Africa, to the Amazon in South America - before the breakup of the Gondwanan super-continent (Fig. (7), after Prescott

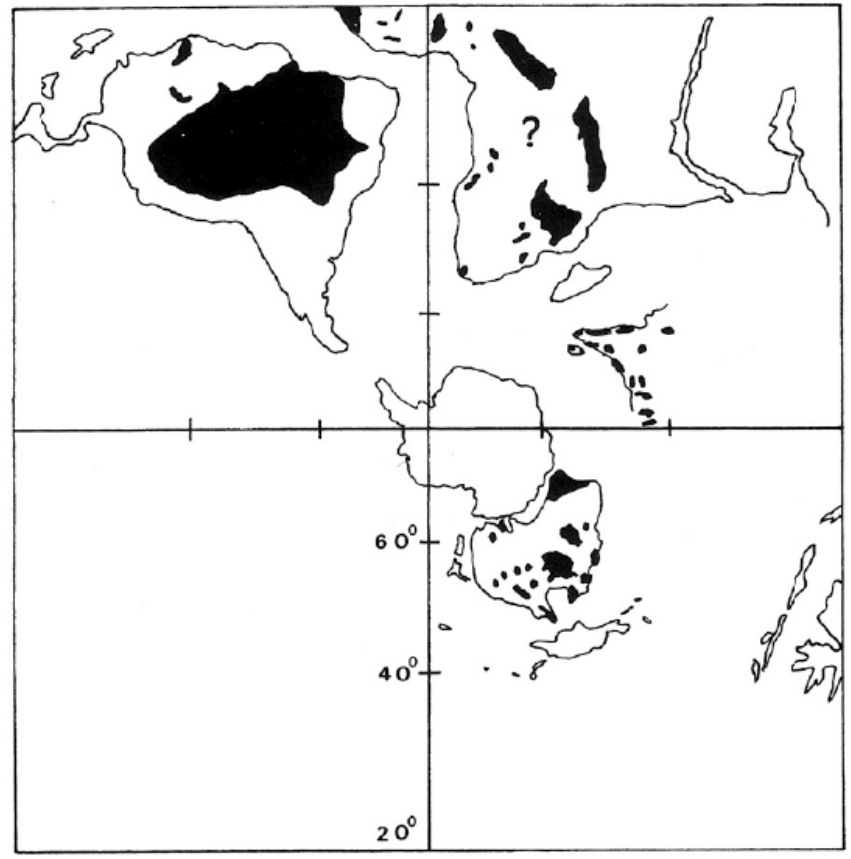

Fig. (7). Distribution of lateritic soils (latosols) on the continental land masses of Gondwanaland (after Prescott \& Pendleton 1952, including recent information in Specht \& Specht 1999, Fig. 6.3). The location of the Gondwanan land masses in the Late Cretaceous, 80 million years ago, is shown on a stereographic projection of the Southern Hemisphere between latitude $20^{\circ} \mathrm{S}$ and the South Pole (Smith \& Briden 1977).

\& Pendleton 1952; Specht \& Specht A. 1999). The lateritic earths - high in kaolinite that fixes phosphate in an unavailable form within its clay lattice - are now dominated by the Darwin Stringybark (Eucalyptus tetrodonta) and many bloodwood eucalypts (now known as Corymbia spp., the fossil imprints of whose leaves with distinctive intramarginal venation indicate that they may have been the earliest eucalypts to evolve in Australia). The fossil fruits of Eucalyptus patagonica that were found in Eocene deposits in South America (Hill 1994), suggests that Australasian eucalypts evolved long before in Gondwanaland (Hill 2004 et al. 1999).

The savanna understorey contains many tropical Gondwanan grass genera that possess a $\mathrm{C} 4$ photosynthetic pathway- in contrast to the usual $\mathrm{C} 3$ photosynthetic pathway in the leaves of the overstorey trees and both native and exotic grasses in southern Australia (Clifford \& Simon 1981; Hattersley 1983). Small trees and shrubs that originally formed part of the Gondwanan rainforests, today survive scattered in the mid-stratum. This wide-spread plant formation had been collected intensely by Robert Brown and colleagues when Captain Matthew Flinders explored the Gulf of Carpentaria in 1802-1803. ${ }^{4}$

\footnotetext{
${ }^{4}$ The first carbon compound produced by photosynthesis in many tropical grasses and Arid Zone chenopods contains four carbon atoms - hence the term C4 photosynthetic plants (Hatch \& Slack 1966). All these C4 plants require a minute trace of sodium ions for development (Brownell \& Wood 1957; Brownell 1965; Brownell \& Jackman 1966; Brownell \& Crossland 1972) - $\mathrm{NaCl}$ in 'cyclic salt' (derived from coastal sea-spray in the atmosphere) or from saliva of grazing animals.In the Arid Zone, the cytoplasmic organelles in the leaves of $\mathrm{C} 4$ grasses, such as Astrebla lappacea, are desiccation-tolerant, being rapidly restored to normal after the next rain (Doley \& Trivett 1974; Mittelheuser 1977).
} 
The ornithologist, Bert Deignan, who was an authority on the avifauna of Thailand, pointed out that quite a few birds of south-eastern Asia have been recorded in northern Australia - either as resident or migratory birds. Bert's survey of the birds of Arnhem Land (Deignan 1964) provided valuable regional data for the numerical analysis of the geographical distribution of land birds of Australia (Kikkawa \& Pearse 1969). Dave Johnson's collection of Arnhem Land mammals (Johnson 1964) was invaluable for an assessment of the number of vertebrate species per latitude-longitude grid-cells (Gamma Biodiversity) throughout the continent (Pianka \& Schall 1981). Bob Miller's and John Bray's collections of amphibian taxa (Mitchell 1964) - supplemented by collections of Gow (1981), Tyler et al. (1983, 1986, 1991), Tyler \& Davies (1986) on Groote Eylandt and across the Top End -were used in an assessment of the Alpha Biodiversity (species richness per hectare) of amphibia and vascular plants throughout the continent (Specht \& Tyler 2010).

A legume Cyclocarpa stellaris was abundant in the paperbark swamp on South Bay, Bickerton Island (Specht 1958 g, p. 242). This species had been collected by jackaroo Len Brass on Settlement Creek Station in the 1920s; later by Rev. N. Michael on Kelsey Creek near Proserpine, Queensland. This tropical West African species has since been recorded across Malaysia and northern Australia (Hacker 1990). ${ }^{5}$

The onset of aridity over the continent of Australia early in the Tertiary (Martin 1998) caused the destruction of many plant formations that had previously been widespread across Australia 50 million years ago. The widespread rainforest species across northern Australia survived only in wellwatered pockets that extended from the Kimberley Region of Western Australia to south-eastern Queensland (Specht 1958b; Webb et al. 1984) where they merged with the southern rainforest flora at the Macpherson-Macleay Overlap zone (Burbidge 1960). Eucalypt open-forests, dominated by Eucalyptus tetrodonta, E. miniata, bloodwoods (Corymbia spp.), with scattered rainforest species in the mid-stratum, and an understorey of tropical $\mathrm{C} 4$ grasses, became widespread on the drier Gondwanan lateritic earths from Cape York Peninsula, Queensland, across the Top End of the Northern Territory into the Kimberley Region of Western Australia (Specht 1981a).

A number of heathy genera that are widespread in the south of the continent survive on the sandstone outcrops of the north together with a species, Triodia microstachya, of the widespread desert spinifex (Specht 1958b): Dilleniaceae (Hibbertia); Epacridaceae (Leucopogon); Fabaceae (Daviesia, Jacksonia); Myrtaceae (Baeckea, Calytrix, Leptospermum, Melaleuca, Verticordia); Proteaceae (Banksia, Grevillea, Hakea, Persoonia). Two species of Leptocarpus in the Family Restionaceae, a characteristic component of heathland vegetation on

\footnotetext{
${ }^{5}$ Jackeroo Len Brass was such a keen plant collector that the Queensland Government Botanist C. T. White nominated him to act as a botanical collector on the Archbold Expeditions to New Guinea and the Solomon Islands. Len became leader of the Archbold Expeditions - the last into Cape York Peninsula in 1948, the same year as the Arnhem Land Expedition. In his retirement, Len, with Joan Wright, a contributor to Flora Zambaica, revitalised the Flecker Herbarium in Cairns, north Queensland.
}

nutrient-poor soils in both southern Australia and South Africa, flourish in wetlands at the base of sandstone hills.

A species of Patersonia (Iridaceae), very similar to a species in south-west Western Australia, was collected by the geologist Herbert Basedow on the Mackay Expedition to Arnhem Land in 1928 (Anon. 1958; Specht 1981a). Species of the genus Calycopeplus (Euphorbiaceae) were recorded from Cape York Peninsula, in Arnhem Land and in southwest Western Australia (Specht 1981a). Species of Borya (Xanthorrhoeaceae), a resurrection plant, have been recorded in northern Queensland, Arnhem Land, the Kimberley and south-west Western Australia, with a species from a single peak in the northern Grampians, Victoria (Specht 1981a). A relictual population of the heathland species, Drummondita calida (Rutaceae), has been found on the western escarpment of the Arnhem Land Plateau - isolated from its other occurrence in the Einasliegh Uplands of northern Queensland; other Drummondita species are common in south-west Western Australia (Woinarski et al. 2009).Even a shrubby species of a Gondwanan rainforest genus, Podocarpus ( $P$. grayae)has persisted in highly excised gully systems draining into the East Alligator River that are separated by more than $1500 \mathrm{~km}$ from its nearest other population in north Queensland (Woinarski et al. 2009). ${ }^{6}$

\section{BIODIVERSITY IN THE ARNHEM LAND VEGETATION}

During the $53,000-60,000$ years that the first huntergatherer settlers (possibly the Mimi-artists) lived in Arnhem Land, they became familiar with all the plants and animals in the Eucalyptus tetrodonta open-forest, wetlands, coastal dunes and mangroves of the lowlands. Apart from sheltering from monsoonal rains in caves and under overhanging rocks, the sandstone hills were largely sacred where secret ceremonies were held, ancestors were buried in caves and rock-paintings recorded their history.

Each tribe had names for all species of plants and animals, as well as for the ecosystems and micro-habitats in which each could be found - not only those species used for food, medicine, tools, culture.

The study of biodiversity in the Arnhem Land vegetation was one of the aims of the botanist, Ray Specht (1958a, 1958b).

- The regional biodiversity of endemic plants in the western Arnhem Land Plateau has been assessed at over 200 species, with 172 plant species restricted to the plateau and a further 25 species mostly restricted to it (Woinarski et al. 2006, 2009). As well, 22 vertebrate species ( 3 fish, 2 frogs, 11 reptiles, 4 birds and 2 mammals) are endemic to the Arnhem Land Plateau (Woinarski et al. 2009).Invertebrates abound in the deep crevices of the Plateau.

- The Species-Richness (number of plant species per hectare) in every area of Eucalyptus tetrodonta openforest that were collected near Darwin, on Groote Eylandt, on Bickerton Island and in north-eastern

\footnotetext{
${ }^{6}$ Both Podocarpus and Nothofagus have been recorded in fossil pollen samples from sediment cores, about 50 million years of age, in the source of the South Alligator River (Truswell 1982; Wilson et al. 1996).
} 
Arnhem Land, were almost identical (Specht 1958g; Langkamp et al. 1981), also at Weipa on Cape York Peninsula (Specht et al. 1977).

- The Species-Richness (number of species per hectare) of both plants (in overstorey and understorey) and resident vertebrates (mammals, birds, snakes, amphibia, lizards) in each ecosystem throughout Australia is determined by the amount of solar energy converted yearly to carbohydrates by the foliage of the plant community (Specht \& Specht A. 1989a, 1989b, 1989c, 1999, pp. 317-338; Braithwaite et al. 1985; Catling 1988; Specht \& Tyler 2010; Specht 2012).

- Background atmospheric radiation (radon \& thoron), when supplemented by radiation from uranium seepage, appears to increase the speciation of unicellular desmids - that divide every few days (Scott \& Prescott 1958; Specht 1976; Ophel et al. 1976; Specht \& Specht A. 1999, pp. 69-70). Plants and animals that have a long reproductive cycle do not appear to be affected by increased background radiation - at least in the Rum Jungle area (W. Bateman, Forestry and Timber Bureau, pers. comm. 1952).

- In the Eucalyptus tetrodonta open-forest, wetlands, coastal dunes and mangroves of the lowlands where physico-chemical processes ensure the dynamic equilibrium of 'structure, growth and biodiversity' in the ecosystem (Specht \& Specht 1999)-the chances of survival of any new species that may have evolved over the last 50 million years will be slim.

- The high Gamma Biodiversity (number of species per region) found in the rainforest of north-eastern Queensland and in the heathland vegetation of south-west Western Australia and on the Hawkesbury Sandstone probably evolved when extreme drought periods occurred during the Tertiary and plants survived only in well-watered pockets. When the vegetation expanded after a favorable climate was restored, the species richness (Alpha Biodiversity, the number of species per hectare) was restored (Specht \& Specht A. 1999, pp. 317-338). Alpha Biodiversity (number of plants per hectare) cannot be restored on the starkly eroded Arnhem Land sandstones in the monsoonal climate of Northern Australia.

\section{MONSOONAL RAINFOREST RESIDUALS}

Rainforest residuals in north-eastern Arnhem Land appeared to survive in habitats that were well supplied with seepage water from adjacent freshwater swamps (Specht 1958a). This subjective observation was supported by the estimates of the 'length of the growing season' of annual crops and pastures in the climatic analysis of tropical Australia made by Professor J. A. Prescott of the Waite Agricultural Research Institute (Prescott 1938). Seasonal growth of the perennial, savanna understorey was confined to the wet summer season, extending for a short time into the dry on stored soil water. The canopies of the eucalypt openforest, however, remained evergreen throughout the dry season under marked water stress.

In the late 1940s, Prescott improved the estimate of the monthly ratio of actual evapotranspiration to potential evapotranspiration (per hectare) in southern Australia (Prescott \& Thomas 1948; Prescott 1949; Prescott et al. 1952). Using the upgraded climatic indices, Specht (1958a) analysed the climate of Northern Australia; the evergreen leaves of the eucalypt open-forest were shown to experience marked water stress during the dry season. In contrast, rainforest pockets would survive only in well-watered habitats (with a 'growing season' approaching twelve months) in this seasonal monsoonal climate. Under these well-watered conditions, bush-fires, widespread in the humid to sub-humid savanna open-forests, would have little effect on the much moister leaves in rainforest residuals (Stocker 1966, 1971; Russell-Smith et al. 2009).

The study of the evapotranspiration (per hectare) from evergreen Australian vegetation became one of the life-long research pursuits of Ray Specht over the next fifty years (Specht \& Specht A. 1999).

In structural formations from the arid to the humid climatic zone, the foliage of both the overstorey $\left(\mathrm{FPC}_{\mathrm{o}}\right)$ and understorey $\left(\mathrm{FPC}_{\mathrm{u}}\right)$ strata influence the monthly rate of actual to potential evapotranspiration per $\mathrm{mm}$ available water. Evapotranspiration (per hectare) is largely from the outside leaves of each plant that composes a plant community. Leaves on vertical foliage shoots within the canopy of each plant are far less exposed to the turbulent aerodynamic fluxes in the atmosphere as it flows over and through the plant community. Monthly evapotranspiration $\left(\mathrm{E}_{\mathrm{a}} \mathrm{mm}\right)$ - measured over several years in arid to humid plant communities (Specht 1957a, 1957b; Martin \& Specht 1962; Carrodus \& Specht 1965; Specht \& Jones 1971; Specht 1972a) - is related to available soil water by the communityphysiological constant, the Evaporative Coefficient (k)

Moisture Index $=E_{a} / E_{o}=E_{a} / E_{p}=k W=k\left(P-R-D+S_{\text {ext }}\right)(1)$

Where Moisture Index $=$ Actual to potential evapotranspiration (Scale $0-1$ )

$\mathrm{E}_{\mathrm{a}}=$ Actual evapotranspiration (mm per month);

$E_{o}=$ Pan evaporation (equivalent to potential evapotranspiration $\mathrm{E}_{\mathrm{p}}$ );

$\mathrm{W}=$ Available water ( $\mathrm{mm}$ per month);

$\mathrm{P}=$ Precipitation (mm per month);

$\mathrm{R}=$ Runoff (mm per month);

$\mathrm{D}=$ Drainage (mm per month);

$\mathrm{S}_{\mathrm{ext}}=$ Extractable soil water at the beginning of month (mm).

$($ Smax $=$ Extractable soil water between Field Capacity and Permanent Wilting Point)

At any climatic site where seasonal water stress occurs, the Evaporative Coefficient is a community-physiological constant - a constant for every month of the year, 


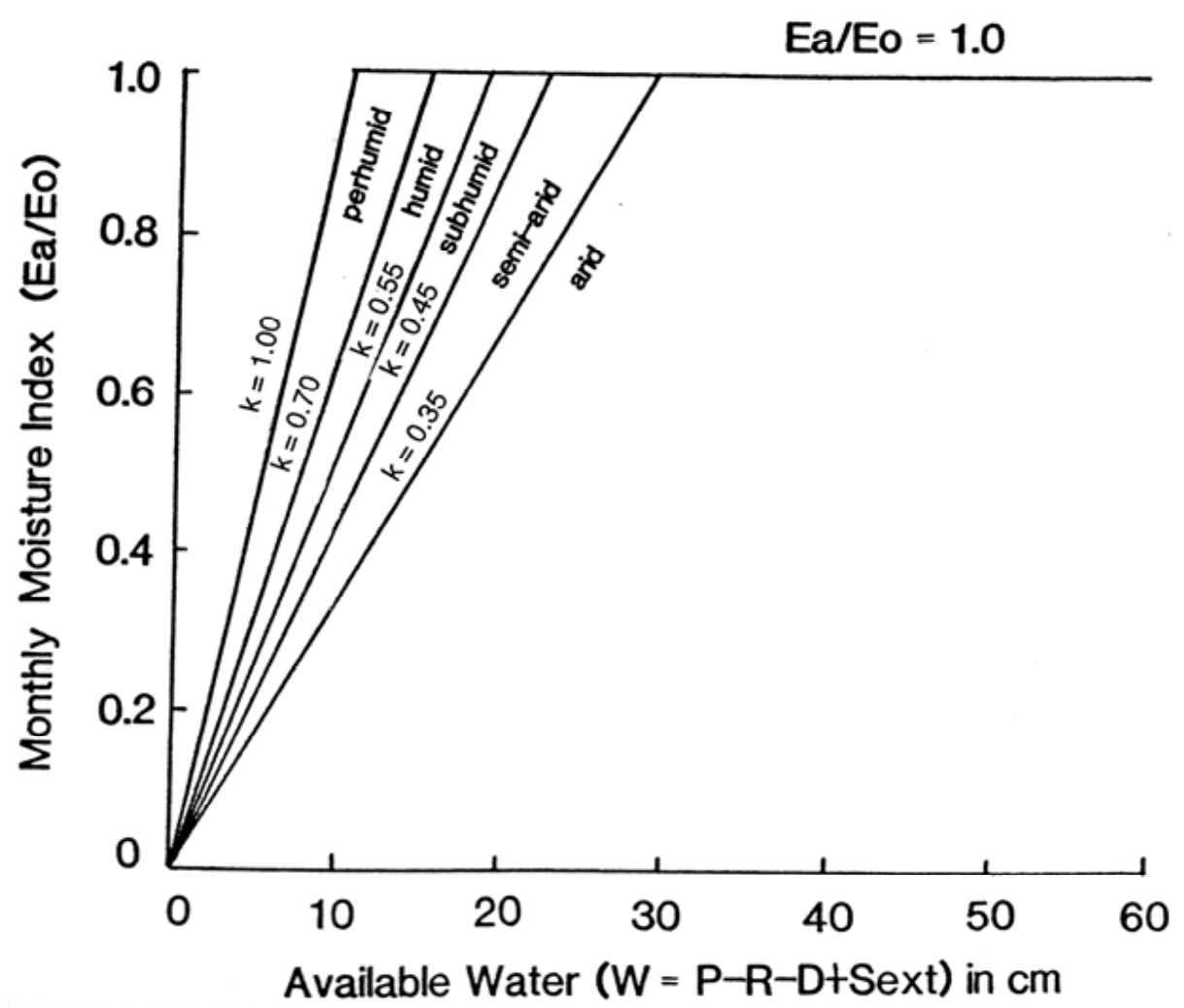

Fig. (8). The effect of increasing complexity of foliage profiles of evergreen plant communities on the Evaporative Coefficient (k), the slope of the linear relationship between the monthly Moisture Index $\left(\mathrm{E}_{\mathrm{a}} / \mathrm{E}_{\mathrm{a}}\right)$ and Available Water (after Specht 1972a).

independent of any variation in monthly or annual rainfall, soil water storage, run-off, or drainage (Specht 1972a). In any evergreen plant community, foliage distribution and attributes, determining the Evaporative Coefficient, are so attuned to aerodynamic fluxes (frictional, thermal, evaporative), that soil water stored during the wet season is utilised during the dry season but never exhausted. This basic observation enables the Evaporative Coefficient - and the Moisture Index (actual to potential evapotranspiration) to be computed for a range of variables in the water-balance Equation (1) at any meteorological site (Fig. 8).

A closed-forest formation, with overstorey $\mathrm{FPC}_{\mathrm{o}}$ greater than $70 \%$ (Specht 1970) invariably develops in a perhumid climate where the water balance of the plant community is optimal to enable actual evapotranspiration to equal potential evapotranspiration during every month of the year (Specht 1972a, 1981b, 1981c, 1981e). In climatic zones that experience seasonal drought, deep well-textured soils may trap sufficient soil water during the wet season or be supplied by a permanent water-table within access of the roots to ensure optimal water supply during every month of the year. This hydrological optimum is clearly demonstrated in the red gum (Eucalyptus camaldulensis) communities in Barmah Forest (Specht 1990), in the paperbark (Melaleuca quinquenervia) communities of subtropical eastern Australia (Specht 1990), in the distribution of rainforest communities on the deep sands of Cooloola (Coaldrake 1961; Webb \& Tracey 1975), on the deep bauxitic soils at Weipa (Specht et al. 1977), on the deep sands of North Stradbroke Island (Clifford \& Specht 1979), and on the coastal dunes of eastern Australia (Specht 1997), and along seepage channels from the deep lateritic earths that had developed over 50 million years ago on the serpentinite outcrop in Central Queensland (Specht et al. 2006).

\section{TIDAL WETLANDS}

All the vast flood-plains associated with river systems across the Top End were stranded when sea-level fell during the four major Ice Ages of the last 400 thousand years (Bardsley et al. 1985). Wetland species survived along the channels that the torrential rains of the monsoonal season had cut across the continental shelf. When the polar ice-caps melted, sea-level flooded back, forcing the freshwater rains to spread across the black soil flood-plains, thus restoring the wetland ecosystem for the multitude of bird life that so excited the Expedition ornithologist, Bert Deignan. Mangrove vegetation, sometimes backed by salt-marsh plants, lined the rivers in which the tidal bore of $7.8 \mathrm{~m}$ (between the highest and lowest astronomical tides) twice daily scoured the black, oozy mud (Saenger et al. 1977). Many of the freshwater wetland plants are widely spread around the coastal regions of Indo-Malaya (Specht 1958b, 1981d); a native rice (Oryza fatua) was harvested by an Aboriginal tribe around Borroloola (Bill Harney, pers. comm. 1948), but was not collected by the Expedition botanist (Specht 1958c).

\section{NUTRIENT TOXICITIES}

Waste products:- Until the establishment of settlements in the $20^{\text {th }}$ Century, Arnhem Land Aborigines were nomadic. 
At coastal camps, sea-shells tended to be deposited in 'kitchen middens' over many centuries and had little effect on the native ecosystems (Specht \& Specht A. 1999, p. 155). Margaret McArthur (1960, p.123) stated that: - "No attempt was made to dispose of waste by any other method than the simple one of flinging it aside. ...... Anything that is edible to dogs or birds is soon removed, and the rest remains". No obvious change in vegetation was noted around camp-sites in Arnhem Land. Around old camp-sites in Bunjalung National Park in northern New South Wales, however, the accumulation of nutrients discarded in waste over many years has encouraged the invasion of Blady Grass (Imperata cylindrica) into the heathy understorey around the camp (Specht \& Specht A. 1999, p. 290).

Calcarenite:- When sea-levels fell during the Glacial Periods of the Quaternary, sand containing calcareous particles was blown ashore from the exposed sea-bed and leached in coastal dunes to form a calcarenite core. In Arnhem Land, this calcareous dust was derived from the fragments of corals and coralline algae - the latter containing the aragonite form of calcium carbonate. This aragonite apparently inhibits the establishment of woody shrubs and trees on the coastal dunes where it has accumulated - only low herbaceous plants now survive (Specht 1958a), markedly in contrast to the woody vegetation on noncalcareous sand-dunes.

In the centre of Arnhem Land, an outcrop of almost pure zinc carbonate (smithsonite) is found on the Bulman Prospect at Mt Marumba. This substrate also inhibits the establishment of woody plants, while the Amaranth Gomphrena canescens (common on the coastal dunes with a calcarenite core) grows profusely on the zinc carbonate outcrop and was found nowhere else (Bateman \& Specht 1958). Over a decade later, Monica Cole from the University of London considered that Gomphrena canescens could be used as a geobotanical indicator of zinc outcrops (Cole et al. 1968). But, as foliar zinc levels - very high in material from Mt Marumba - were found to be low in material collected from coastal dunes (Specht \& Rayson unpubl. zinc analyses, 1952), it may be simply high $\mathrm{pH}$, not zinc, that this species can tolerate.

Background uraniferous radiation in seepage water: When uranium mining began at Rum Jungle in the early 1950s, the Forestry and Timber Bureau forester Bill Bateman could not find any influence of high radiation from the ore on eucalypts (with a long reproductive cycle) growing on the site.

Samples of the uni-cellular algae associated with pondweed in freshwater swamps were collected near the base camps of the Arnhem Land Expedition. The desmid species in these samples were identified by Arthur Scott, a world specialist in New Orleans, U.S.A. (Scott \& Prescott 1958; Croasdale \& Scott 1976). The collection made in Unawalerke Lagoon near Oenpelli was teeming with desmids, some of the most beautiful, strangest and rarest that Scott had ever seen (Specht \& Specht 1999, p. 70). This collection contained 164 desmid taxa (48 undescribed), far richer in taxa than other samples (10-25 taxa) collected elsewhere in the Northern Territory, South Australia or overseas (Prescott \& Scott 1952; Scott \& Prescott 1958).
Phreatoicidean isopods also show 'micro-endemism' in Arnhem Land with one or two unique taxa each with a small apparent range, maybe less than a kilometre (Wilson et al. 2009). South of Gunbalanya, Wilson found three species and in the North Jabiluka outlier there were as many as 11 species.

The seasonally waterlogged, infertile, sandy soils in the humid and sub-humid climates of the Northern Territory supports a diverse assemblage of short-lived plant species (Cowie 2005) - Utricularia L. with 36 taxa (Taylor 1989); Eriocaulon L. with 21 taxa (Leach 2000); Lindernia All. with over 25 taxa (WR Barker, unpublished data). Speciation has also occurred in genera such as Byblis Salisb., Calandrinia Kunth., Centrolepis Labill., Oldenlandia L., Stylidium Willd., Trithuria Hook. f. and Typhonium Schott all of which are found on seasonally waterlogged substrates (Cowie 2005).

Controlled experiments by radiation biologists of Chalk River Atomic Research Station, Canada, had shown that small genetic changes in populations of developing trout embryos increased linearly when sperms were exposed to background radiation from zero to several levels above normal background (McGregor \& Newcombe 1972; Ophel et al. 1976, reported in Specht 1976 and Specht \& Specht A. 1999, p.69). As catchment water seeping over uriniferous rocks may contain levels as high as $1.8 \mathrm{mg}$ per litre (compared with normal levels of $0.25 \mathrm{mg}$ per litre), it is possible that the high number of desmid taxa (that reproduce by binary fission every few days) in Unawalerke Lagoon may have resulted from increased radiation levels in the water. This hypothesis has still not been tested in Arnhem Land.

\section{CONSERVATION}

The 'Conservation of Major Plant Communities in Australia and Papua New Guinea' (Specht et al. 1974a) was compiled under the auspices of the International Biological Programme and the Australian Academy of Science. No conservation reserve included the sandstone complex and wetlands in Northern Australia.

This deficit in the conservation network was queried during the Ranger Uranium Inquiry in Sydney, June 1976 (Specht 1976). Although it was considered that these ecosystems were well conserved in the Arnhem Land Aboriginal Reserve with indigenous people as caretakers, Kakadu National Park (1.98 million hectares) was declared as a conservation reserve for tourists. The unique Gondwanan flora and ancient rock-art of the sandstone hills in the Arnhem Land Aboriginal Reserve have recently (2009) been conserved in the Warddeken Indigenous Protected Area (1.4 million hectares).

Specht, R. L. (1976). Ranger Uranium Environmental Inquiry. Sydney, June 16th 1976. from:

Submission prepared by Ray Specht, with assistance

Dr Ivan Ophel, Atomic Energy of Canada, Chalk River, Canada

Dr David Doley, Botany Dept., University of Queensland 
i. The Arnhem Land Escarpment: - A National Monument (Specht 1958a; Specht et al. 1974a).

ii. Kakadu National Park was declared in 1977.

iii. Sensitivity of the sandstone ecosystems to environmental change (Specht 1963; Heddle \& Specht 1975).

iv. Sensitivity of the black soil flood-plain ecosystems to environmental change (later Bardsley et al. 1985).

v. The effect of background radiation on the speciation of unicellular algae (Scott \& Prescott 1958; McGregor \& Newcombe 1972; Ophel et al. 1976; Specht \& Specht A. 1999, pp. 69-70).

vi. Revegetation and weeds (later Bardsley et al. 1985; Clifford \& Specht 1986)

Uranium, bauxite and manganese mining, however, could over-ride Aboriginal land-rights in the Arnhem Land Aboriginal Reserve. Nancy Williams $(1986,1987)$ worked with the Yolngu to solve land-rights conflicts in the Yirrkala area.

The biodiversity of small mammals in ecosystems in Northern Australia is closely paralleled by the biodiversity of plants in the same ecosystem (Braithwaite et al. 1985). This biodiversity relationship depends on the amount of foliage produced annually in the overstorey that is capable of fixing solar energy by photosynthesis (Specht \& Specht A. 1989b).

Fire was used as a management tool by Aborigines to conserve fauna (Nicholson 1981; Specht \& Specht A. 1999). Dave Johnson noted (1964, p. 447) that: - "The practice of burning of the ground vegetation that is indulged in every year by Aborigines throughout Arnhem Land destroys the habitat of some kinds of ground-dwelling small mammals. The bandicoots (Isoodon macrourus) seem better able than other kinds to survive fire, perhaps because they customarily take shelter in hollow logs that are only slightly scorched by the brief fires. There is no doubt, however, that the bandicoot population is greatly reduced as a result of the burning. In the small patches of forest understorey that escape fires, nests and runways of bandicoots can always be found." Aboriginal firing of small areas of the savanna understorey was delayed until populations of small mammals and reptiles had returned to pre-fire levels (McArthur 1960). This recovery needed about three years post-fire (Braithwaite 1996a, 1996b). Studies on the management of fires in North Australian savannas were reviewed by 15 authors in 'Rekindling the Wurrk Tradition' (Russell-Smith et al. 2009).

Although some faunal species may be rare, it is doubtful whether they will be endangered in Arnhem Land - unless some major perturbation such as Global Warming or the invasion of water buffalo or cane toads occurs. Even the secretive White-Throated Grasswren (Amytornis woodwardi) is not rare, if one has the patience of Bert Deignan to sit for hours to see the bird flit between clumps of Spinifex (Triodia microstachya) on top of the Arnhem Land Escarpment (Deignan 1964, p. 401). By 1948, the Cattle Egret (Ardeola ibis) that was first released in the Kimberley in 1933 to combat cattle tick had reached Oenpelli in hundreds (Deignan 1964); the species reached Victoria in 1949 and New Zealand in 1963-64 (Pizzy1980).
Over many thousands of years, the original settlers have wisely managed the ecosystems in Arnhem Land - to ensure the continual supply of plant and animal foods. Elders ensured the conservation of this unique landscape, passing on knowledge in stories, songs and dance. Over the last century, the influence of the elders in the education of their children has been taken over by the settlements. Today, local communities must become closely involved again in the conservation of the ecosystems in their region (Finlayson $e t$ al. 1998a, 1998b; Altman 2011).

\section{INTERNATIONAL IMPACT OF THE ECOLOGICAL STUDIES OF THE ARNHEM LAND EXPEDITION}

\section{Invitation to Join the Arnhem Land Expedition}

When Charles Mountford returned from his second lecture tour in the United States in August 1946, he approached Prof. J. G. Wood of the Botany Department of the University of Adelaide to suggest a botanist to join the five-man team that would form the National Geographic Expedition to Arnhem Land in 1947. Ray Specht, an Adelaide Teachers' College student, who was undertaking an ecological survey of the most complicated area of the Mt Lofty Ranges for his Hons B.Sc. research (Specht \& Perry 1948), was invited to join the Expedition. Leave was granted from the Education Department of South Australia and frantic preparations were made to be ready to depart north in February 1947. In January 1947, the Smithsonian Institution requested that the Expedition be delayed until 1948 so that scientists could be sent to monitor Bikini Atoll before the Hydrogen Bomb Tests. Ray took up an appointment as a teacher at Adelaide High School - to serve part of his bond of six years to the Education Department of South Australia. Three months later, he was coopted on a 'Grassland Survey of the South East of South Australia' (Tiver \& Crocker 1951) by the Waite Agricultural Research Institute. At the Waite where University and CSIRO Soils Division scientists worked in the same building, he was exposed to brilliant scientists in climatology, soils, mineral nutrition, plant physiology, plant ecology, insect and animal ecology, plant pathology. Thanks to his holistic training in education, Ray was able to absorb, understand and integrate many of these basic problems that were being tackled by scientists in the Waite Institute.

\section{Botanical Collections of the Arnhem Land Expedition}

The American-Australian Scientific Expedition to Arnhem Land in 1948 formed strong bonds between biologists in the United States and Australia - both in the field and later when sets of botanical specimens (collected by Ray Specht) were deposited (by the Department of Information) in the Herbaria of the Smithsonian Institution, Washington, D.C., and in the Arnold Arboretum, Jamaica Plains, Massachusetts. The latter Herbarium had sponsored the Archbold Expeditions to New Guinea and the Solomon Islands and, in 1948, had mounted the last Archbold Expedition, this time into Cape York Peninsula under the leadership of Queenslander Len Brass.

Other international bonds were formed when sets of the botanical collections were deposited (by the Department of Information) in the Herbarium of the Royal Botanical Gardens at Kew, England, and in the Rijksherbarium at Leiden, Amsterdam. The latter Herbarium was anxious to 
obtain plant material from Northern Australia to use in its major research production of the Flora Malesiana.

\section{Fulbright Program}

As monies from the sale of war-time equipment left behind in Australia and New Zealand after the Pacific Campaign in the Second World War could not be transferred back to the United States, Senator Fulbright proposed a scheme for the exchange of scholars and scientists between the U.S.A. and Australasia. Early in the 1950s, several Fulbright Fellows from California and Arizona spent a year in Adelaide at the Waite Agricultural Research Institute, CSIRO Soils and Animal Nutrition Divisions and in the Botany Department of the University of Adelaide. The young Lecturer in Botany, Ray Specht, became a close colleague of all.

Perry Stout and Clarence Johnson of the Mineral Nutrition Department of the University of California, Berkeley, were fascinated by the field trials that had been initiated on Dark Island heathland, near Keith in the NinetyMile Plain, South Australia, to explore how Australian native plants survived on soils that needed superphosphate fertilizer to enable agricultural crops and pastures (also radiata pine plantations) to develop (Specht 1963; Heddle \& Specht 1975; Specht \& Specht A. 1989c).

Most heathland plants responded to applied superphosphate - the greatest response being in short-lived understorey species that benefited from the ashes left by a bush-fire, the least response in long-lived overstorey species. Increased growth rates, however, led to earlier deaths. The increased phosphate stored in the top-soil then inhibited (by 'phosphorus toxicity', Ozanne \& Specht 1981) the regeneration of heathland seedlings germinating after fire; exotic invasive plants flourished to turn the heathland into a herbaceous grassland (Specht 1963; Heddle \& Specht 1975; Specht \& Specht A. 1989c; Specht \& Specht A. 1999, pp. 282-286) - probably also stimulated with the production of nitrate rather than ammonium ions in the soil (Stewart et al. 1990). These field experiments, extending over 40 years, clearly explained the sharp disjunction between heathy understorey on nutrient-poor soils and grassy understorey on medium-nutrient soils that was observed in the Mount Lofty Ranges (Adamson \& Osborn 1924; Specht \& Perry 1948).

In order to survive for millions of years on nutrient-poor soils, heathland plants (also eucalypts) developed a biochemical strategy to conserve phosphate ions released from decomposing litter. During the period of minimum foliage growth in overstorey heathland plants - winter through spring in the Mediterranean-type climate of southern Australia - orthophosphates produced from decomposition of litter is stored as long-chain polyphosphates in rootlets and associated rhizosphere organisms. When active foliage growth begins in late spring into summer, the polyphosphates in rootlets are hydrolysed back to orthophosphates and transported in the xylem stream into developing leaf primordia (Specht \& Groves 1966; Jeffrey 1964, 1968; Haines 1967; Coleman \& Specht 1981, Specht et al. 1983; Specht \& Specht A. 1999, pp. 297-301).

At the same time, one of Ray's post-graduate students, Peter Brownell, was exploring whether the traces of sodium chloride in sea-spray (blown far inland) could be essential, not detrimental, for native plants. Peter found that traces of sodium were essential for the growth of saltbush (Atriplex vesicaria) and, later, when he moved to Townsville, for many tropical C4 grasses (Brownell \& Wood 1957; Brownell 1965; Brownell \& Jackman 1966; Brownell \& Crossland 1972). Plant nutritionists in the University of California, Berkeley, paralleled Peter's research in Adelaide on the essentiality of chloride. Both a world first!

Fulbright Fellow Prof. Walt Phillips from the University of Arizona, Tucson, spent a year in the Botany Department studying Arid Zone ecology on Koonamore Vegetation Reserve and in Central Australia. At the same time, Fulbright Scholar Dorothy Taylor from Duke University, North Carolina, undertook a research comparison between the Arid Zone vegetation on Koonamore and in south-eastern Arizona.

Clark Ashby (formerly a research scientist in the San Dimas Research Station in Southern California) of the United States Department of Agriculture (U.S.D.A.), Washington, D.C. and Lincoln Ellison of the U.S.D.A. Wasatch (subalpine) Forestry Research Station, Utah, made special trips to Dark Island heathland from their Fulbright hosts in Sydney and Brisbane respectively. Plant biochemist James Bonner and the constant-environment Phytotron Director Fritz Went from CALTEC (Californian Institute of Technology) at Pasadena, California, also visited the Botany Department to discuss various aspects of ecophysiology/biochemistry of arid zone plants.

All these Fulbrighters encouraged Ray Specht to apply for a Fulbright Fellowship to work with them in the U.S.A. Australasian Fulbrighters, however, received only a travel grant - not a per diem - during their stay in the U.S.A. Later, Senator Smith Mundt introduced a grant for a daily allowance for the Australasian Fulbrighters. In 1956, Ray Specht was awarded a Fulbright-Smith Mundt Fellowship to study for six months in the Nutrition Department of the University of California, Berkeley. A Carnegie Foundation Grant for three months enabled (1) an analysis of the structural and growth dynamics of chaparral in stands aged up to 35 years post-fire on San Dimas Experiment Station in the Mediterranean-type climate of southern California (Specht 1969), and (2) a survey of Arid Zone research in the cold and hot deserts of the United States (Specht 1958e).

After the survey of the research in Arid Zone plant communities from Idaho to Texas, the Spechts visited freshwater algal expert Arthur Scott in New Orleans (Scott $\&$ Prescott 1958), then drove east to study mineral nutrition research in south-eastern U.S.A. In Washington, D.C., Ray renewed contact with the Smithsonian scientists, Frank Setzler and Bert Deignan. The National Geographic Society gave a luncheon in Ray's honour followed by a viewing of Howell Walker's Arnhem Land film; Ray was flattered to add his signature in the Visitors Book after Polar Explorer Admiral Richard Byrd (1888-1957). Later, the Spechts visited Bob Miller and family in Ann Arbor, Michigan, before crossing into Canada to visit university-colleague Ivan Ophel at the Chalk River Atomic Research Station in upstate Ontario.

UNESCO Arid Zone Research Programme (1950s) 
In the 1950s, UNESCO sponsored international cooperation in tackling desertification throughout the world. The outstanding Arid Zone Research that had been conducted by the Botany Department, under Prof. J. G. Wood, and under Prof. J. A. Prescott in the Waite Agricultural Research Institute of the University of Adelaide formed the basis for the Australian Arid Zone Research Programme. In 1951, a research program on the effect of climatology and microclimatology on the structure and growth of arid zone plant communities was proposed by the Planning Committee (under the Chair of Prof. J. G. Wood) modelled on the research being developed by Ray Specht on Dark Island heathland near Keith in the Ninety-Mile Plain, South Australia.

Later during sabbatical leave in 1956, Specht was asked to survey the research being undertaken in Arid Zone Research Stations in the United States (Specht 1958e) - in Arizona, Idaho, Nevada, New Mexico, Texas, and Utah under the sponsorship of a Carnegie Foundation grant. This survey became the basis for the formation of AustralianAmerican Rangeland Conferences and later the International Rangeland Society. Ray was pleased to learn of the research into overstorey and understorey covers in a mesquite thinning experiment (Parker \& Martin 1952) near Tucson, Arizona, and in the sagebrush (Spring or Fall) grazing experiment at the Sheep Experiment Station at Dubois, Idaho (Director of Experiment Station pers. comm.). This relationship between the foliage covers of overstorey and understorey strata had already emerged in a post-fire study (up to 25 years) in regenerating Dark Island heathland (Specht et al. 1958).

In October 1956, UNESCO and CSIRO sponsored a Symposium on 'Climatology and Microclimatology' (UNESCO 1958) in Canberra to precede the Olympic Games in Melbourne. Ray Specht presented a paper, in absentia, on 'Micro-environment (soil) of a natural plant community' (Specht 1958d). This research on water relations in Dark Island heathland and in the arid zone on Koonamore Vegetation Reserve stirred the imagination of leading scientists from abroad - Prof. L. Emberger (Montpellier, France), Prof. H. Geiger (Munich, Germany), Dr J. L. Monteith (Rothamsted Experiment Station, U.K.), Prof. C. W. Thornthwaite (Laboratory of Climatology, Elmer, N.J., U.S.A.) and later Prof. M. Evanari (Jerusalem, Israel) and Prof. H. Walter (Germany). Much later in 1972, Prof. L. E. Rodin of Leningrad, U.S.S.R., invited Ray Specht to present a paper in an Arid Zone Symposium held in Samarkand (Specht 1972a). ${ }^{7}$

After eight months in the United States, the Spechts spent two months in Montpellier in southern France in the Station Internationale de Géobotanique Méditerranéenne et Alpine under the direction of 70 year old Prof. J. Braun-Blanquet. There, Ray studied the structure and growth of garrigue (Quercus coccifera) vegetation regenerating post-fire over 15 years, the oldest stand available (Specht 1969). Towards the end of his stay in Montpellier, he had the pleasure of meeting Prof. Louis Emberger on his return from the

${ }^{7}$ Major references: - Emberger 1955, 1959; Evenari et al. 1971; Geiger 1965; Monteith 1958, 1973; Rodin 1972; Thornthwaite 1948, 1958; Walter 1968.
UNESCO - CSIRO symposium on 'Climatology and Microclimatology' held in Canberra, Australia, and Gilbert Long (1974) who directed the Centre National de la Recherche Scientifique (C.N.R.S.) Arid Zone Research Programme in North Africa.

The research of Specht became even more widely known - much to Ray's amazement.

\section{International Biological Programme}

While on a Royal Society - Nuffield Foundation Scholarship to Oxford University in 1964, Ray Specht was coopted as a member of two Planning Committees for the International Biological Programme (IBP) - an international proposal of the International Council of Scientific Unions (ICSU) that had sponsored the very successful International Geophysical Year (IGY) in 1958. IBP Planning Committees for Section PT Productivity of Terrestrial Ecosystems and Section PP Production Processes were held in Paris in 1965; these IBP Planning Committees were preceded by a Planning Committee for IBP Section CT Conservation of Terrestrial Ecosystems, held in Monks Wood, Huntingdonshire, England, at which Ray outlined the 'Conservation Survey of Major Plant Communities in Australia' (Day 1968; Specht et al. 1974a), being conducted under the auspices of the Australian Academy of Science.

Ray's research on 'The Physico-Chemical Processes that determine the Dynamics of Structure, Growth and Biodiversity in Plant Communities' in Australia, the United States and France formed the basis for IBP Section PP, SubSection Community-physiology (Specht 1967, 2011). This unique research aimed to understand how plant formations closed-forest, open-forest, woodland, scrub, tall shrubland, low shrubland, grassland, heathland, hummock grassland, etc. - maintained their structure throughout their life-cycle from regeneration to maturity and senescence in tropical, subtropical and temperate Australia (Specht \& Specht A. 1999).

The IBP-PP research proposal on the 'Dynamics of Structure, Growth and Biodiversity' (Specht \& Specht A. 1999) was so challenging that it continued through the IBP Biome Research Program, especially in the study of Mediterranean-type Climate Biomes (di Castri \& Mooney 1973), ICSU-SCOPE (Special Committee on the Preservation of the Environment) - 'Fire and the Australian Biota' (Gill et al. 1981) and 'Biogeography of Mediterranean Invasions' (Groves \& di Castri 1991); ICSUISOMED (International Society for Mediterranean Ecosystems) to the present day (George et al. 1979; Edmonds \& Specht MM 1981; Greenslade \& Majer 1985; Noble \& Bradstock 1989; Specht 1988b, 1988c; Specht \& Rundel 1990; Specht et al. 1981, 1983, 1990, 1991; Arianoutsou \& Groves 1994; Specht \& Specht A. 1995, 1999). As a pioneer in the study of Mediterranean-climate ecosystems, Ray Specht was invited to present papers at many of these conferences - Israel (1970-71); Valdivia, Chile (1971); Palo Alto, California (1975); Stellenbosch and Cape Town, South Africa (1980); San Diego, California (1981); Montpellier, France (1983); Perth, Western Australia (1984); Sesimbra, Portugal (1985); Barcelona and Zaragoza, Spain (1985); Woods Hole, Mass. (1986); Montpellier, 
France (1987); Thessaloniki, Greece (1988); Alicante and Barcelona, Spain (1990); Crete, Greece (1991); Renaca near Santiago, Chile (1994); Stellenbosch, South Africa (2000). In 1983, Ray Specht was awarded a Fulbright Senior Scholarship to spend one month in the Biology Department, Stanford University and five months with the Systems Ecology Research Group, San Diego State University in California. ${ }^{8}$

The IBP study of 'Ecosystems of the World' was further stimulated by the publication of a thirty volume series by Elsevier (Goodall, Gen. Editor, 1977-2006).

\section{International Union for the Conservation of Nature}

Towards the end of the IBP conservation survey of major plant communities in Australia (Specht et al. 1974a), Dr Ron Melville of Kew Herbarium visited Australia for the Pan Pacific Science Conference held in Canberra in 1971. In his retirement, Melville had accepted the challenge of IUCN (International Union for the Conservation of Nature) to prepare a 'Red Data Book of Endangered Plants'. Staff of the major Australian herbaria readily cooperated with the IBP Conservation Committee to list (with their distributions) the primitive seed plants in the Australian flora possessing: (1) primitive floral characters (Specht et al.1974b); 2 primitive morphological characters (Melville \& Specht 1974). The species considered to be rare and endangered in each State/Territory of Australia were listed in the same publication (Specht et al.1974a). The presence of only a few plants of a species, however, enabled that species to be nominated as 'rare and endangered' in one State, although it was common over the State border in an adjacent State. This national problem was painstakingly solved over the next decades (Leigh et al. 1981; Groves \& Ride 1982; Briggs \& Leigh 1988, 1996).

\section{Australian Heritage Commission and World Wildlife (Aust.) Fund}

The installation of high-speed computers in the University of Queensland and in Canberrra - with financial support from the Australian Heritage Commission, CSIRO Division of Computing Research, the University of Queensland and Southern Cross University - enabled all the species-lists recorded in ecological surveys throughout Australia (Specht, M \& Specht 1962) to be compiled in 17 large data-bases and Floristic Groups to be defined by the polythetic-divisive classificatory program TWINSPAN. The conservation status of these objectively-defined Floristic Group was then assessed in the 'Conservation Atlas of Plant Communities of Australia' (Specht et al. 1995). Only 37\% of these TWINSPAN Floristic Groups were adequately conserved, some $22 \%$ were reasonably conserved.

'A Method for Selecting Nature Conservation Reserves' in regions of Australia where almost no ecosystems had been conserved was devised - supported by the World Wildlife (Aust.) Fund (Bolton \& Specht 1983; Purdie 1987).

\section{International Geosphere-Biosphere Programme}

\footnotetext{
${ }^{8}$ The Director of the Systems Ecology Research Group, Phil Miller, with his wife Patsy and Joachim Kummerow, spent Christmas 1970 camping on Dark Island heathland, South Australia to understand the ecosystem research that we had initiated (Specht 1973b; Miller 1981).
}

In 1987, sponsored by UNESCO Ecology Commission, the MEDECOS Conference in Montpellier, France, focussed on 'Time Scales of Biological Responses to Water Constraints' (Eds J. Roy, J. Aronson \& F. di Castri, SPB Academic Publishing, Amsterdam, 1995) as one of the initial contributions to the ICSU International GeosphereBiosphere Programme on Global Warming.

Ray Specht \& Mary Dettmann (1995) traced the 'Palaeoclimatology of Australia and current physiological functioning of plant communities' since the Late Cretaceous (50-100 million years ago).

Ray and Alison Specht (1995) looked into the future and 'Predicted changes in structure and species richness of Mediterranean ecosystems in southern Australia' - based on the physico-chemical processes that determine the structure, growth and biodiversity of Australian plant communities (and associated consumers and decomposers).

On Groote Eylandt, the Holocene pollen record from a dunefield lake indicated that effective precipitation reached a maximum between 5,000 and 4,000 years BP. A decline in precipitation occurred after 4,000 years BP until rainfall increased slightly during the last millennium in tandem with an increase in the burning regime (Schulmeister 1992; Schulmeister \& Lees 1995). With increasing carbon dioxide in the upper atmosphere since the Industrial Revolution, Global Warming appears inevitable - with marked changes on all Australian terrestrial ecosystems.

The Statewide Landcover and Trees Study (SLATS 19912009; Lucas et al. 2006) in Queensland - to assess annual land clearing rates and the effect of Global Warming throughout the State - has been based on the effect of aerodynamic fluxes (frictional, thermal and evaporative) on the lateral growth of foliage (Foliage Projective Cover) of all plants in overstorey and understorey strata within a plant community (Specht 1972a; Specht \& Specht A. 1999; Specht et al. 2006).

\section{CONFLICT OF INTEREST}

The authors confirms that this article content has no conflicts of interest.

\section{ACKNOWLEDGEMENTS}

Many thanks are due to Emanuela Appetiti, medical ethnobotanist of the Institute for the Preservation of Medical Traditions at the Smithsonian Institution, who painstakingly edited this manuscript.

\section{APPENDIX A}

Records of the American-Australian Scientific Expedition to Arnhem Land

(Melbourne University Press, Melbourne)

Vol. 1. Art, Myth and Symbolism. (Ed. Charles P. Mountford, 1956)

The story of the Expedition. (Charles P. Mountford, pp. xxi$\mathrm{xxx}$ )

Part 1. Aboriginal art of Australia. (Charles P. Mountford, pp.3-15) 
Part 2. The art of Groote Eylandt. (Charles P. Mountford, pp.19-106)

Part 3. The art of Oenpelli. (Charles P. Mountford, pp.109-264)

Part 4. The art of Yirrkalla. (Charles P. Mountford, pp.267-411)

Part 5. Carved and painted figures. (Charles $P$. Mountford, pp.415-475)

Part 6. Astronomy. (Charles P. Mountford, pp.479-508)

Vol. 2. Anthropology and Nutrition (Ed. Charles P. Mountford, 1960)

Chap. 1. Report of the Nutrition Unit. (Ed. Margaret McArthur)

Introduction. (Margaret McArthur, pp. 1-13)

Food consumption and dietary levels of Aborigines at the Settlements. (Margaret McArthur, pp. 14-26)

The health and nutritional status of the Aborigines. (Brian P. Billington, pp. 27-59)

The dental and periodontal conditions of Aborigines at Settlements. (John E. H. Moody, pp. 60-71)

Biochemical assessments of nutritional status. (Kelvin J. Hodges, pp. 72-89)

Food consumption and dietary levels of groups of Aborigines living on naturally occurring foods. (Margaret McArthur, pp. 90-135)

Analysis of naturally occurring foodstuffs of Arnhem Land. (Catherine F. Fysh, Kelvin J. Hodges \& Lorraine Y. Siggins, pp. 136-139)

Conclusions and recommendations. (Margaret McArthur, pp. 139-143)

Chap. 2. The food quest and the time factor in Aboriginal economic life. (Frederick D. McCarthy \& Margaret McArthur, pp. 145-194)

Chap. 3. Hair of Australian Aborigines. (Mildred Trotter, Oliver H. Duggins \& Frank M. Setzler, pp. 195202)

Chap. 4. Dermatoglyphs of Australian Aborigines. (Harold Cummins \& Frank M. Setzler, pp. 203-214)

Chap. 5. The archaeology of Arnhem Land. (Frederick D. McCarthy \& Frank M. Setzler, pp. 215-295)

Chap. 6. The cave paintings of Groote Eylandt and Chasm Island. (Frederick D. McCarthy, pp. 297-414)

Chap. 7. The string figures of Yirrkalla. (Frederick D. McCarthy, pp. 415-511)

Vol. 3. Botany and Plant Ecology (Eds Ray L. Specht \& Charles P. Mountford, 1958)

Chap. 1. History of botanical exploration in the Arnhem Land Aboriginal Reserve. (Ray L. Specht, pp. 1-7)

Chap. 2. Some freshwater algae from Arnhem Land. (Arthur M. Scott \& Gerald W. Prescott, pp. 9-136)
Chap. 3. Some Characeae from Arnhem Land. (Richard D. Wood, p. 137)

Chap. 4. Marine algae from Arnhem Land. (H. Bryan S. Womersley, pp. 139-161)

Chap. 5. Some Basidiomycetes collected in Arnhem Land. (G. H. Cunningham, pp. 163-165)

Chap. 6. Some Agaricaceae collected in Arnhem Land. (R. W. G. Dennis, p. 167)

Chap. 7. Some lichens collected in Arnhem Land. (Patrick Bibby, p. 169)

Chap. 8. Some Bryophytes collected in Arnhem Land. (David G. Catcheside, p. 169)

Chap. 9. The Pteridophytes of Arnhem Land. (Mary D. Tindale, pp. 171-184)

Chap. 10. The Gymnospermae and Angiospermae collected on the Arnhem Land Expedition. (Ray L. Specht, pp. 185-317)

Chap. 11. Plants collected by Dr H. Basedow on the Mackay Expedition in Arnhem Land, 1928. (Anon., pp. 319-325)

Chap. 12. Some ecological and systematic notes on the vegetation near Mt Marumba in the centre of Arnhem Land. (William Bateman \& Ray L. Specht, pp. 327-331)

Chap. 13. The climate, geology, soils and plant ecology of the northern portion of Arnhem Land. (Ray L. Specht, pp. 333-414)

Chap. 14. The geographical relationships of the flora of Arnhem Land. (Ray L. Specht, pp. 415-478)

Chap. 15. An introduction to the ethno-botany of Arnhem Land. (Ray L. Specht, pp. 479-503)

\section{Vol. 4. Zoology (Ed. R. L. Specht, 1964)}

Chap. 1. History of zoological collections in Arnhem Land Aboriginal Reserve. (Marion M. Specht, pp. 1-7)

Chap. 2. Molluscs of Arnhem Land. (Bernard C. Cotton, pp. 9-43)

Chap. 3. Fishes of Arnhem Land. (William R. Taylor, pp. 45-307)

Chap. 4. Reptiles and amphibians of Arnhem Land. (Francis J. Mitchell, pp. 309-343)

Chap. 5. Birds of the Arnhem Land Expedition. (Herbert G. Deignan, pp. 345-425)

Chap. 6. Mammals of the Arnhem Land Expedition. (David H. Johnson, pp. 427-515)

\section{APPENDIX B}

\section{Exploring the Legacy of the 1948 Arnhem Land Expedition}

(Eds Martin Thomas \& Margo Neale)

Published by The Australian National University, E Press, Canberra, 2011. 
1. Expedition as a time capsule: Introducing the American-Australian Scientific Expedition to Arnhem Land. (Martin Thomas, pp. 1-30)

\section{Part I. Engagements with Aboriginal Cultures}

2. Inside Mountford's tent, politics and paperwork. (Philip Jones, pp. 33-54)

3. Nation Building or Cold War: Political settings for the Arnhem Land Expedition. (Kim Beazley, pp. 55-71)

4. A Robinson Crusoe in Arnhem Land: Howell Walker, National Geographic and the Arnhem Land Expedition of 1948. (Mark Collins Jenkins, pp. 7385)

5. Birds on the Wire: Wild sound, informal speech and the emergence of the radio documentary. (Tony MacGregor, pp. 87-111)

6. From Kunnanji, Fish Creek, to Mumeka, Mann River: Hunter-gatherer tradition and transformation in Western Arnhem Land, 1948-2009. (Jon Altman, pp. 113-134)

7. Making a Sea Change: Rock art, archaeology and the enduring legacy of Frederick McCarthy's research on Groote Eylandt. (Anne Clarke \& Ursula Frederick, pp. 135-155)

8. Ecology and the Arnhem Land Expedition: Raymond Specht, a botanist in the field. (Lynne McCarthy, pp. 157-169)

9. Piecing the History Together: An overview of the 1948 Arnhem Land Expedition. (Sally May, pp. 171-188)

\section{Part II. Collectors and Collections}

10. The String Figures of Yirrkala: Examination of a legacy. (Robyn McKenzie, pp. 191-212)

11. The Forgotten Collection: Baskets reveal histories. (Louise Hamby, pp. 213-238)

12. Hidden for Sixty Years: The motion pictures of the American-Australian Scientific Expedition to Arnhem Land. (Joshua Harris, pp. 239-251)

13. The Responsibilities of Leadership: The records of Charles P. Mountford. (Denise Chapman \& Suzy Russell, pp.253-269)

14. Beneath the Billabongs: The scientific legacy of Robert Rush Miller. (Gifford Hubbs Miller and Robert Charles Cashner, pp. 271-282)

15. An Insider's Perspective: Raymond Louis Specht's oral history. (Ed. Margo Daly, pp. 283-310)

\section{Part III. Aboriginal Engagements with the Expedition}

16. The American Clever Man (Marrkijbu Burdan Merika). (Bruce Birch, pp. 313-336)

17. Missing the Revolution! Negotiating disclosure on the pre-Macassans (Bayini) in North-East Arnhem Land. (Ian S. McIntosh, pp. 337-354)
18. Aural Snapshots of Musical Life: The 1948 recordings. (Linda Barwick \& Allan Marett, pp. 355-375)

19. Unpacking the Testimony of Gerald Blitner: Crosscultural brokerage and the Arnhem Land Expedition. (Martin Thomas, pp. 377-401)

20. The Forbidden Gaze: The 1948 Wubarr ceremony performed for the American-Australian Scientific Expedition to Arnhem Land. (Murray Garde, pp. 403-421)

21. Epilogue: Sifting the silence. (Margo Neale, pp. 423-436).

\section{REFERENCES}

Adamson, RS \& Osborn, TGB (1924) The ecology of the Eucalyptus forests of the Mount Lofty Ranges (Adelaide District), South Australia. Transactions of the Royal Society of South Australia 48, 87-144.

Altman, J. (2011) From Kunnanj, Fish Creek, to Mumeka, Mann River: Hunter-gatherer tradition and transformation in Western Arnhem Land, 1948-2009. In: Thomas, M \& Neale, M (Eds). Exploring the Legacy of the 1948 Arnhem Land Expedition. Australian National University E Press, Canberra, Australia 113-34.

Anon. (1958) Plants collected by Dr H. Basedow on the Mackay Expedition in Arnhem Land, 1928. In: Specht, RL \& Mountford, CP (Eds) Records of the American-Australian Scientific Expedition to Arnhem Land. Vol. 3. Botany and Plant Ecology. Melbourne University Press, Melbourne, Australia 319-25.

Appetiti, E (2005) Remedies from the bush: Traditional medicine among the Australian Aborigines. In: Zohara Yaniv \& Uriel Bachrach (Eds) Handbook of Medicinal Plants. Food Products Press: Haworth Medical Press, New York, U.S.A 175-90.

Archer, M (1981) A review of the origins and radiation of Australian mammals. In: Keast, A (Ed). Ecological Biogeography of Australia. Junk, The Hague, The Netherlands 1435-88.

Arianoutsou, M \& Groves, RH (Eds) (1994) Plant-Animal Interactions in Mediterranean-Type Ecosystems. Kluwer Scientific Publications, Dordrecht, The Netherlands.

Bardsley, KN, Davie, JDS \& Woodroffe, CD (Eds) (1985) Coasts and Tidal Wetlands of the Australian Monsoonal Region. Australian National University, North Australian Research Unit, Mangrove Monograph No. 1, Darwin, Australia.

Barwick, L \& Marett, A (2011) Aural Snapshots of Musical Life: The 1948 recordings. In: Thomas, M \& Neale, M (Eds) Exploring the Legacy of the 1948 Arnhem Land Expedition. Australian National University E Press, Canberra, Australia 355-75.

Bassett-Smith, P (1998a) Peter Bassett-Smith, Australian Department of Information. In: Specht, RL \& Specht, A (Eds) Personal Experiences on the 'Coast of Adventure'. Arnhem Land Reunion, Sydney, $27^{\text {th }}-28^{\text {th }}$ June 1998 . Southern Cross University, Lismore, New South Wales, Australia 48 .

Bassett-Smith, P (1998b) The search for the Phoenix. In: Specht, RL \& Specht, A (Eds) Personal Experiences on the 'Coast of Adventure'. Arnhem Land Reunion, Sydney, $27^{\text {th }}-28^{\text {th }}$ June 1998. Southern Cross University, Lismore, New South Wales, Australia 70-73.

Bateman, W \& Specht, RL (1958) Some ecological and systematic notes on the vegetation near Mt Marumba in the centre of Arnhem Land. In: Specht, RL \& Mountford, CP (Eds) Records of the AmericanAustralian Scientific Expedition to Arnhem Land. Vol. 3. Botany and Plant Ecology. Melbourne University Press, Melbourne, Australia 327-331.

Beazley, K (2011) Nation Building or Cold War: Political settings for the Arnhem Land Expedition. In: Exploring the Legacy of the 1948 Arnhem Land Expedition. Australian National University E Press, Canberra, Australia 55-71.

Bibby, P (1958) Some lichens collected in Arnhem Land. In: Specht, RL \& Mountford, CP (Eds) Records of the American-Australian Scientific Expedition to Arnhem Land. Vol. 3. Botany and Plant Ecology. Melbourne University Press, Melbourne, Australia 169.

Billington, BP (1960) The health and nutritional status of the Aborigines. In: Mountford, CP (Ed) Records of the American-Australian Scientific 
Expedition to Arnhem Land. Vol. 2. Anthropology and Nutrition. Melbourne University Press, Melbourne, Australia 27-59.

Billington, BP (1998) Experiences of the medical officer. In: Specht, RL \& Specht, A (Eds) Personal Experiences on the 'Coast of Adventure'. Arnhem Land Reunion, Sydney, $27^{\text {th }}-28^{\text {th }}$ June 1998. 39-40. Southern Cross University, Lismore, New South Wales, Australia.

Birch, B (2011) The American Clever Man (Marrkijbu Burdan Merika). In: Thomas, M \& Neale, M (Eds) Exploring the Legacy of the 1948 Arnhem Land Expedition. Australian National University E Press, Canberra, Australia 313-36.

Blake, ST (1953) Botanical contributions of the Northern Australian Regional Survey, I, Studies on Northern Australian species of Eucalyptus. Australian Journal of Botany, 1, 185-352.

Bolton, MP \& Specht, RL (1983) A Method of Selecting Nature Conservation Reserves. Australian National Parks and Wildlife Service Occasional Paper No. 8, Canberra, Australia.

Braithwaite, RW (1996a) A healthy savanna, endangered mammals and Aboriginal burning. In: Rose, DB (Ed) Country in Flames. Australian National University, North Australia Research Unit, Biodiversity Series, Paper No. 3, Darwin, Australia 91-102.

Braithwaite, RW (1996b) Biodiversity and fire in the savanna landscape. Chapter 7. In: Solbrig, OT, Medina, E. \& Silva, JF (Eds) Biodiversity and Savanna Ecosystem Processes. A Global Perspective. Ecological Studies Vol. 121. Springer-Verlag, Berlin, Germany.

Braithwaite, RW, Winter, JW, Taylor, JA \& Parker, BS (1985) Patterns of diversity and structure of mammalian assemblages in the Australian tropics. Australian Mammalogist 8, 171-86.

Brandl, EJ (1988) Australian Aboriginal Paintings in Western and Central Arnhem Land. Aboriginal Studies Press, Canberra, Australia.

Briggs, JD \& Leigh, JH (1988) Rare or Threatened Australian Plants. Revised Edition. Australian National Parks \& Wildlife Service, Special Publication No. 14, Canberra, Australia.

Briggs, JD \& Leigh, JH (1996) Rare or Threatened Australian Plants. Fourth Edition. CSIRO Publishing, Melbourne, Australia.

Brownell, PF (1965) Sodium as an essential micro-nutrient element for a higher plant (Atriplex vesicaria). Plant Physiology, 40, 460-68.

Brownell, PF \& Crossland, CJ (1972) The requirement for sodium as a micro-nutrient by species having the $\mathrm{C} 4$ dicarboxylic photosynthetic pathway. Plant Physiology, 49, 794-97.

Brownell, PF \& Jackman, ME (1966) Changes during recovery from sodium deficiency in Atriplex. Plant Physiology, 41, 617-22.

Brownell, PF \& Wood, JG (1957) Sodium, an essential micro-nutrient element for Atriplex vesicaria Heward. Nature, 179, 635-36.

Burbidge, NT (1960) The phytogeography of the Australian region. Australian Journal of Botany, 8, 75-211.

Carmichael, L (June 1960) The Smithsonian: Magnet on the Mall. National Geographic Magazine, 117(6), 796-845.

Carrodus, BB \& Specht, RL (1965) Factors affecting the relative distibution of Atriplex vesicaria and Kochia sedifolia (Chenopodiaceae) in the arid zone of South Australia. Australian Journal of Botany, 13, 419-33.

Catcheside, DG (1958) Some bryophytes collected in Arnhem Land. In: Specht, RL \& Mountford, CP (Eds) Records of the AmericanAustralian Scientific Expedition to Arnhem Land. Vol. 3. Botany and Plant Ecology. Melbourne University Press, Melbourne, Australia 169.

Catling, PC (coordinator) (1988) Vertebrates. In: Specht, RL (Ed) Mediterranean-type Ecosystems. A Data Source Book. Kluwer Academic Publishers, Dordrecht, The Netherlands 171-94.

Cawte, JE (1984) Emic accounts of a mystery illness: the Groote Eylandt syndrome. Australian and New Zealand Journal of Psychiatry, 18, $179-87$.

Cawte, JE (1985) Psychiatric sequeles of manganese exposure in the adult, foetal and neonatal nervous systems [plus editorial comment]. Australian and New Zealand Journal of Psychiatry, 19, 211-17.

Cawte, JE (1990) Australia - Land-dwellers' Response to Mineral Extremes in East Arnhem Land: Some Neuropsychiatric Issues. Manuscript, AIATSIS Library, Canberra, Australia.

Cawte, JE (1996) Healers of Arnhem Land. University of New South Wales Press, Sydney, Australia.

Cawte, JE (1998) Aboriginal medicine, Elcho Island. In: Specht, RL \& Specht, A (Eds) Personal Experiences on the 'Coast of Adventure'. Arnhem Land Reunion, Sydney, $27^{\text {th }}-28^{\text {th }}$ June 1998. Southern Cross University, Lismore, New South Wales, Australia 44-45.
Chapman, D \& Russell, S (2011) The Responsibilities of Leadership: The records of Charles P. Mountford. In: Thomas, M \& Neale, M (Eds) Exploring the Legacy of the 1948 Arnhem Land Expedition. Australian National University E Press, Canberra, Australia 25369.

Chappell, J (1982) Sea levels and sediments. Some features of the context of coastal archaeological sites in the tropics. Archaeology in Oceania 17, 69-78.

Christian, CS \& Stewart, GA (1953) General Report on Survey of the Katherine-Darwin Region, 1946. C.S.I.R.O. (Aust.) Land Resource Series No. 1, Melbourne, Australia.

Clarke, A \& Frederick, U (2011) Making a Sea Change: Rock art, archaeology and the enduring legacy of Frederick McCarthy's research on Groote Eylandt. In: Thomas, M \& Neale, M (Eds) Exploring the Legacy of the 1948 Arnhem Land Expedition. Australian National University E Press, Canberra, Australia 13555 .

Clarke, PA (2007) Aboriginal People and their Plants. Rosenberg Publishing Ltd, Dural, New South Wales, Australia.

Cleland, JB (1966) The ecology of the Aboriginal in South and Central Australia. In: Cotton, BC (Ed.) Aboriginal Man in South and Central Australia. Government Printer, Adelaide, Australia 111-58.

Clifford, HT \& Simon, BK (1981) The biogeography of Australian grasses. In: Keast, A (Ed.) Ecological Biogeography of Australia. Junk, The Hague, The Netherlands 537-54.

Clifford, HT \& Specht, RL (1979) The Vegetation of North Stradbroke Island. (With notes on the fauna of mangrove and marine meadow ecosystems by Specht, MM) University of Queensland Press, St Lucia, Queensland, Australia.

Clifford, HT \& Specht, RL (Eds) (1986) Tropical Plant Communities. Their Resilience, Functioning and Management in Northern Australia. The Utah Foundation \& Dept. Botany, University of Queensland, St Lucia, Queensland, Australia.

Coaldrake, JE (1961) The Ecosystems of the Coastal Lowlands (Wallum) of Southeastern Queensland. CSIRO (Aust.) Bulletin No. 238.

Cole, K (1984) Fred Gray of Umbakumba. Keith Cole Publications, Bendigo, Victoria, Australia.

Cole, MM, Provan, DMJ \& Tooms, JS (1968) Geobotany, biogeochemistry and geochemistry in mineral exporation in the Bulman-Waimuna Springs area, Northern Territory, Australia. Transactions of the Institution of Mining and Metallurgy (Section B, Applied Earth Science,) 77, B81-104.

Coleman, RG \& Specht, RL (1981) Mineral nutrition of heathlands; The possible role of polyphosphate in the phosphorus economy of heathland species. In: Specht, RL (Ed) Ecosystems of the Worlds. Vol. 9B. Heathlands and Related Shrublands. Analytical Studies. Elsevier, Amsterdam, The Netherlands 197-207.

Collis, C (2012) Ancient artists of rock and soul. Monash University Delivering Impact, June 2012, 4-7.

Commander Allied Land Forces, South West Pacific Area (1943) Friendly Fruits and Vegetables. Arbuckle Waddell, Melbourne, Australia.

Cotton, BC (1964) Molluscs of Arnhem Land. In: Specht, RL (Ed) Records of the American-Australian Scientific Expedition to Arnhem Land. Vol. 4. Zoology. Melbourne University Press, Melbourne, Australia $9-44$.

Cowie, ID (2005) Goodenia elaiosoma I.D. Cowie (Goodeniaceae), a new species from the Top End of the Northern Territory and a key to the northern species. Austrobaileya, 7(1), 205-13.

Cribb, AB \& Cribb, JW (1974, revised 1990) Wild Food in Australia. Collins, Sydney, Australia.

Cribb, AB \& Cribb, JW (1981, revised 1990) Wild Medicine in Australia Collins-Angus and Robertson, Sydney, Australia.

Croasdale, H \& Scott, AM (1976) New or otherwise interesting desmids from Northern Australia. Nova Hedwigia, 27, 501-95.

Cummins, H \& Setzler, FM (1960) Dermatoglyphics of Australian Aborigines. In: Records of the American-Australian Scientific Expedition to Arnhem Land. Vol. 2.Anthropology and Nutrition. (Ed. C. P. Mountford). Melbourne University Press, Melbourne, Australia 203-14.

Cunningham, GH (1958) Some Basidiomycetes collected in Arnhem Land, Northern Territory. In: Specht, RL \& Mountford, CP (Eds) Records of the American-Australian Scientific Expedition to Arnhem Land. Vol. 3. Botany and Plant Ecology. Melbourne University Press, Melbourne, Australia 163-66.

Daly, M (Ed) (2011) An insider's perspective: Raymond Louis Specht's oral historyIn: Thomas, M \& Neale, M (Eds) Exploring the Legacy of 
the 1948 Arnhem Land Expedition. Australian National University E Press, Canberra, Australia 283-310.

David, B \& Chant, D (1995) Rock art and regionalisation in North Queensland prehistory. Memoirs of the Queensland Museum, 37, 357-528.

Day, M (Ed.) (1968) National Parks and Reserves in Australia. Australian Academy of Science Report No. 9, Canberra, Australia.

Deignan, HG (1950a) A tentative revision of the Australian races of the Grey-crowned Babbler, Pomatostomus temporalis (Vigors and Horsfield), with descriptions of two new subspecies. The Emu, $50(1), 17-21$.

Deignan, HG (1950b) Two new races of the Spotted Nightjar, Eurostopodus guttatus (Vigors and Horsfield). The Emu, 50(1), 21-23.

Deignan, HG (1951) A new frogmouth from Groote Eylandt, Gulf of Carpentaria. The Emu, 51(1), 71-73.

Deignan, HG (1964) Birds of the Arnhem Land Expedition. In: Specht, RL (Ed) Records of the American-Australian Scientific Expedition to Arnhem Land. Vol. 4. Zoology. Melbourne University Press, Melbourne, Australia 345-426.

Dennis, RWG (1958) Some Agaricaceae collected in Arnhem Land, Northern Territory. In: Specht, RL \& Mountford, CP (Eds) Records of the American-Australian Scientific Expedition to Arnhem Land. Vol. 3. Botany and Plant Ecology. Melbourne University Press, Melbourne, Australia 167-68.

Dewar, M (1992) The 'Black War' in Arnhem Land. Missionaries and the Yolngu Australian National University, North Australian Research Unit, Darwin, Australia 1908-1940.

Di Castri, F \& Mooney, HA (Eds) (1973) Mediterranean Type Ecosystems. Origin and Structure. Springer-Verlag, New York, U.S.A.

Diels, L (1906) Die Pflanzenwelt von West-Australien südlich des Wendekreises. Wilhelm Engelmann, Leipzig, Germany.

Doley, D \& Trivett, NBA (1974) Effects of low water potentials on transpiration and photosynthesis in Mitchell Grass (Astrebla lappacea). Australian Journal of Plant Physiology, 1, 539-50.

Edmonds, SJ \& Specht, MM (1981) Dark Island heathland, South Australia: Faunal rhythms. In: Specht, RL (Ed) Ecosystems of the World. Vol. 9b. Heathlands and Related Shrublands. Analytical Studies. Elsevier, Amsterdam, The Netherlands 15-27.

Egan, T (1996) Justice All Their Own. The Caledon Bay and Woodah Island Killings Melbourne University Press, Melbourne, Australia 19321933.

Emberger, L (1955) Une classification biogéographique des climats. Revue Travaille Laboratoire Botanique Faculté de Science, Montpellier, 7, 3-43.

Emberger, L (1959) La place de l'Australie méditerranéenne dans l'ensemble des pays méditerranéens du vieux monde. (Remarques sur le climat méditerranéen de l'Australie) In: Keast, A, Crocker, RL\& Christian, CS (Eds)Biogeography and Ecology in Australia. Junk, Den Haag, The Netherlands 259-73.

Evanari, M, Shanan, L \& Tadmor, NH (1971) The Negev: The Challenge of a Desert. Harvard University Press, Cambridge, Massachusetts, U.S.A.

Ewart, AJ \& Davies, OB (1917) The Flora of the Northern Territory. Minister for Home and Territories, Melbourne, Australia.

Faulkner, P \& Clarke, A (2004) Late-Holocene occupation and coastal economy in Blue Mud Bay, northeast Arnhem Land: Preliminary archaeological findings. Australian Archaeology, 59, 23-30.

Finlayson, M, Thurtell, L, Storrs, M, Appelgate, R, Barrow, P \& Wellings, $P$ (1998a) Local communities and wetland management in the Australian wet-dry tropics. In: Specht, RL \& Specht, A (Eds) Personal Experiences on the 'Coast of Adventure'. Arnhem Land Reunion, Sydney, $27^{\text {th }}-28^{\text {th }}$ June 1998 . Southern Cross University, Lismore, New South Wales, Australia 64.

Finlayson, M, Yibarbuk, D, Thurtell, L, Storrs, M \& Cooke, P (1998b) Local community Management of the Blyth/Liverpool wetlands, Arnhem Land, Northern Territory, Australia. In: Specht, RL \& Specht, A (Eds) Personal Experiences on the 'Coast of Adventure'. Arnhem Land Reunion, Sydney, $27^{\text {th }}-28^{\text {th }}$ June 1998. Southern Cross University, Lismore, New South Wales, Australia 65-68.

Fisher, C \& Calaby, J (Ed. RC Willan) (2009) The Top of the Top End: John Gilbert's Manuscript Notes for John Gould on Vertebrates from Port Essington and Cobourg Peninsula (Northern Territory, Australia); with Comments on Specimens Collected during the Settlement Period 1838 to 1849, and Subsequently. The Beagle Records of the Museums and Art Galleries of the Northern Territory Supplement No. 4.
Frith, HJ \& Calaby, JH (Eds) (1974) Fauna Survey of the Port Essington District, Cobourg Peninsula, Northern Territory of Australia. CSIRO Division of Wildlife Research Technical Paper No. 28, Melbourne, Australia.

Fysh, CF, Hodges, KJ \& Siggins, LY (1960). Analysis of naturally occurring foodstuffs of Arnhem Land. In Mountford, CP (Ed) Records of the American-Australian Scientific Expedition to Arnhem Land. Vol. 2. Anthropology and Nutrition. Melbourne University Press, Melbourne, Australia 136-39.

Garde, M (2011) The Forbidden Gaze: The 1948 Wubarr ceremony performed for the American-Australian Scientific Expedition to Arnhem Land. In: Thomas, M \& Neale, M (Eds) Exploring the Legacy of the 1948 Arnhem Land Expedition. Australian National University E Press, Canberra, Australia 403-21.

Geiger, R (1965) The Climate near the Ground. (translated from the fourth German edition of Das Klima der Boddennahen Luftschicht.) Harvard University Press, Cambridge, Massachusetts, U.S.A.

George, AS, Hopkins, AJM \& Marchant, NG (1979) The heathlands of Western Australia. In: Specht, RL (Ed) Ecosystems of the World. Vol. 9a. Heathlands and Related Shrublands. Descriptive Studies. Elsevier, Amsterdam, The Netherlands 211-30.

Gill, AM, Groves, RH \& Noble, IR (Eds) (1981) Fire and the Australian Biota. Australian Academy of Science, Canberra, Australia.

Goodall, DW (Gen. Ed.) (1977-2006) Ecosystems of the World. 30 Vols. Elsevier, Amsterdam, The Netherland.

Gow, GG (1981) Herpetofauna of Groote Eylandt, Northern Territory.Australian Journal of Herpetology, 1: 62-9.

Greenslade, P \& Majer, JD (Eds) (1985) Soil and Litter Invertebrates of Australian Mediterranean-Type Ecosystems. Western Australian Institute of Technology, School of Biology Bulletin No. 12.

Groves, RH \& di Castri, F (Eds) (1991) Biogeography of Mediterranean Invasions. Cambridge University Press, Cambridge, England.

Groves, RH \& Ride, WDL (Eds) (1982) Species at Risk: Research in Australia. Australian Academy of Science, Canberra, Australia.

Hacker, JB (1990) A Guide to Herbaceous and Shrub Legumes of Queensland. University of Queensland Press, St Lucia, Queensland, Australia.

Haines, WM (1967) Experimental Approaches to the Study of Seasonal Root Activity and Phosphorus Nutrition of Australian Heath Plants. M. Sc. Thesis, University of Melbourne, Melbourne, Australia.

Hamby, L (2011) The Forgotten Collection: Baskets reveal history. In: Thomas, M \& Neale, M (Eds) Exploring the Legacy of the 1948 Arnhem Land Expedition. Australian National University E Press, Canberra, Australia 213-38.

Harris, J (2011) Hidden for Sixty Years: The motion pictures of the American-Australian Scientific Expedition to Arnhem Land. In: Thomas, M \& Neale, M (Eds) Exploring the Legacy of the 1948 Arnhem Land Expedition. Australian National University E Press, Canberra, Australia 239-51.

Harris, JW (1979) Ethnoscience and its Relevance for Education in Traditional Aboriginal Communities. M. Sc. Thesis, University of Queensland, St Lucia, Queensland, Australia.

Hartley W (1942) Two new Eriachne species from Arnhem Land, Northern Territory. Journal of the Linnean Society (Botany), 52, 344-5.

Hatch, MD \& Slack, CR (1966) Photosynthesis by sugar cane leaves - a new carboxylation reaction and the pathway of sugar formation. Biochemistry Journal, 101, 103-11.

Hattersley, PW (1983) The distribution of C3 and C4 grasses in Australia in relation to climate. Oecologia 57, 113-28.

Heddle, EM \& Specht, RL (1975) Dark Island heath (Ninety-Mile Plain, South Australia). 8. The effect of fertilizers on composition and growth, 1950-1972. Australian Journal of Botany, 23, 151-64.

Hegarty, MP, Hegarty, EE \& Wills, RBH (2001) Food Safety of Australian Plant Bush Foods. Rural Industry Research \& Development Corporation Publication No. 01/28, Canberra, Australia.

Hill, RS (1994) The history of selected Australian taxa. pp. 390-419. In: Hill, RS (Ed) History of Australian Vegetation: Cretaceous to Recent. Cambridge University Press, Cambridge, England.

Hill, RS (2004) Origins of the southeastern Australian vegetation. Philosophical Transactions of the Royal Society of London, B 359, 1537-49.

Hill, RS Truswell, EM, McLoughlin, S \& Dettmann, ME (1999) Evolution of the Australian flora: Fossil evidence. In: Flora of Australia. Vol. 1. Introduction. Second Edition. CSIRO Publishing, Melbourne, Australia 251-320. 
Hodges, KJ (1960). Report of the biochemical assessments of nutritional status. In: Mountford, CP (Ed) Records of the American-Australian Scientific Expedition to Arnhem Land. Vol. 2. Anthropology and Nutrition. Melbourne University Press, Melbourne, Australia 7289.

Hooker, JD (1860). On the flora of Australia, being part of an Introductory Essay to Flora Tasmaniae. The botany of the Antarctic voyage of H. M. discovery ships Erebus and Terror, in the years 1839-1843. Part III, 1, xxcvii-cxxviii. Reeve, London, England.

Hynes, RA \& Chase, AK (1982) Plants, sites and domiculture: Aboriginal influence upon plant communities in Cape York Peninsula. Archaeology in Oceania, 17, 38-50.

Irvine, FR (1957) Wild and emergency food of Australian and Tasmanian Aborigines. Oceania, 28, 113-42.

Irvine, FR (unpubl. post 1958) Bibliography of Food Plants of Australian Aborigines. The Herbarium, Royal Botanic Gardens, Kew, England.

Isaacs, J (1992) Bush Food. Aboriginal Food and Herbal Medicine. Ure Smith Press, Sydney, Australia.

James, SM (1998). The saga of the Sajara. In: Specht, RL \& Specht, A (Eds) Personal Experiences on the 'Coast of Adventure'. Arnhem Land Reunion, Sydney, $27^{\text {th }}-28^{\text {th }}$ June 1998. Southern Cross University, Lismore, New South Wales, Australia 74-81.

Jeffrey, DW (1964) The formation of polyphosphate in Banksia ornata, an Australian heath plant. Australian Journal of Biological Science, $17,845-54$.

Jeffrey, DW (1968) Phosphate nutrition of Australian heath plants. II. The formation of polyphosphate by five heath species. Australian Journal of Botany, 16, 603-13.

Jenkins, MC (2011) A Robinson Crusoe in Arnhem Land: Howell Walker, National Geographic and the Arnhem Land Expedition of 1948. In: Exploring the Legacy of the 1948 Arnhem Land Expedition. Australian National University E Press, Canberra, Australia 73-85.

Johnson, DH (1954) A new marsupial of the genus Antechinus from northern Australia. Proceedings of the Biological Society of Washington, 67, 77-80.

Johnson, DH (1955) The incredible kangaroo. National Geographic Magazine, 108, 487-500.

Johnson, DH (1959) Four new mammals from the Northern Territory of Australia. Proceedings of the Biological Society of Washington, 72, 183-8.

Johnson, DH (1964) Mammals of the Arnhem Land Expedition. In: Specht, RL (Ed) Records of the American-Australian Scientific Expedition to Arnhem Land. Vol. 4. Zoology. Melbourne University Press, Melbourne, Australia 427-515.

Jolliffe, E (Oct. 30 ${ }^{\text {th }}$ 1948) Arnhem Land Expedition cartoons. PIX Weekly, Vol. 21, No. 16.

Jones, P (2011) Inside Mountford's tent, politics and paperwork. In: Exploring the Legacy of the 1948 Arnhem Land Expedition. Australian National University E Press, Canberra, Australia 33-54.

Kikkawa, J \& Pearse, K (1969) Geographical distribution of land birds in Australia - a numerical analysis. Australian Journal of Zoology 17, 821-40.

Kiloh, LG \& Cawte, JE (1987) A neurological ethnic-geographic isolate on Groote Eylandt. In: Fleming, K (Ed) Proceedings of a Conference at Health House. Northern Territory Department of Health, Darwin, Australia. (Imprint, AIATSIS Library, Canberra). 14-17.

Kirk, RL (1981) Physiological, demographic and genetic adaptation of Australian Aboriginals. In: Ecological Biogeography of Australia. (Ed. A. Keast) Junk, The Hague, The Netherlands 1799-1816.

Lachner, EA \& Taylor, WR (1960) A new cardinal fish of the genus Archamia from northern Australia. Proceedings of the Biological Society of Washington, 73, 29-34.

Lamshed, M (1972). 'Monty' The Biography of C. P. Mountford. Rigby, Adelaide, Australia.

Langkamp, PJ, Ashton, DH \& Dalling, MJ (1981) Ecological gradients in forest communities on Groote Eylandt. Vegetatio, 48, 27-46.

Leach, GJ (2000) Notes and new species of Eriocaulon (Eriocaulonaceae) from Australia. Australian Systematic Botany, 13, 755-72.

Leeding, VJ (1998) A tribute to the Umbakumba Aborigines. In: Specht, RL \& Specht, A (Eds) Personal Experiences on the 'Coast of Adventure'. Arnhem Land Reunion, Sydney, 27-28 th June 1998. Southern Cross University, Lismore, New South Wales, Australia 57-59.

Leeding, VJ (2006) Dictionary of the Enindilyakwa Language, Groote Eylandt. CD-Rom.
Leigh, JH, Briggs, JD \& Hartley, W (1981) Rare or Threatened Australian Plants. Australian National Parks \& Wildlife Service. Special Publication No. 7, Canberra, Australia.

Lentfer, C (1998) Umbakumba - A teacher's perspective from the 1980s. In: Specht, RL \& Specht, A (Eds) Personal Experiences on the 'Coast of Adventure'. Arnhem Land Reunion, Sydney, 27 $7^{\text {th }}-28^{\text {th }}$ June 1998. Southern Cross University, Lismore, New South Wales, Australia 60-63.

Levitt, D (1981) Plants and People. Aboriginal Uses of Plants on Groote Eylandt. Australian Institute of Aboriginal Studies, Canberra, Australia.

Long, G (1974) Diagnostic Phyto-Écologique et Aménagement du Territoire. Masson et Cie., Éditeurs, Paris, France.

Lucas, RM Cronin, N, Moghaddam, M, Lee, A, Armston, J, Bunting, P \& Witte, C (2006) Integration of radar and Landsat-derived foliage projected cover for woody regrowth mapping, Queensland, Australia. Remote Sensing of Environment, 100, 388-406.

MacGregor, T (2011) Birds on the Wire: Wild sound, informal speech and the emergence of the radio documentary. In: Thomas, M \& Neale, M (Eds) Exploring the Legacy of the 1948 Arnhem Land Expedition. Australian National University E Press, Canberra, Australia 87-111.

Macknight, CC (1976) The Voyage of Marege: Macassan Trepangers in Northern Australia. Melbourne University Press, Melbourne, Australia.

Macknight, CC \& Thorne, AG (1968) Two Macassan burials in Arnhem Land. Archaeology and Physical Anthropology in Oceania, 3, 21622.

Marean, CW, Bar-Matthews, M, Bernatchez, J, Fisher, E, Goldbergs, P, Herries, AIR, Jacobs, Z, Jerardino, A, Karkanas, P, Minichillo, T, Nilssen, PJ, Thompson, E, Watts, I, \& Williams, HM (2007) Early human use of marine resources and pigment in South Africa during the Middle Pleistocene. Nature 449, 905-9.

Martin, HA (1998) Tertiary climatic evolution and the development of aridity in Australia. Proceedings of the Linnean Society of New South Wales, 119, 115-36.

Martin, HA \& Specht, RL (1962) Are mesic communities less drought resistant? A study on moisture relationships in dry sclerophyll forest at Inglewood, South Australia. Australian Journal of Botany, $10,106-18$.

May, SK (2000) The Last Frontier? Acquiring the American-Australian Scientific Expedition Ethnographic Collection 1948. B.A. Hons. Thesis, Flinders University, Adelaide, Australia.

May, SK (2005) Karrikadjurren: Creating Community with an Art Centre in Indigenous Australia. Ph.D. Thesis, Australian National University, Canberra, Australia.

May, SK (2009) Collecting Cultures. Myth, Politics and Collaboration in the 1948 Arnhem Land Expedition. Alta Mira Press, Berkeley, California, U.S.A.

May, SK (2011) Piecing the History Together: An overview of the 1948 Arnhem Land Expedition. In: Thomas, M \& Neale, M (Eds) Exploring the Legacy of the 1948 Arnhem Land Expedition. Australian National University E Press, Canberra, Australia. pp. $171-88$.

May, SK, Gumurdul, D, Manakgu, J, Maralngurra, G \& Nawirridj, W (2005) "You Write it Down and Bring it Back, That's What We Want" - Revisiting the 1948 Removal of Human Remains from Gunbalanya (Oenpelli), Australia. In: Smith, C \& Wobst, HM (Eds) Indigenous Archaeologies: Decolonising Theory and Practice. Routledge, New York, U.S.A 110-30.

May, SK, McKinnon, J \& Raupp, J (2009) 'Boats on Bark: an analysis of Groote Eylandt bark paintings featuring Macassan praus from the 1948 Arnhem Land Expedition. International Journal of Nautical Archaeology, 38, 369-85.

McArthur, M (1960a) Food consumption and dietary levels of groups of Aborigines living on naturally occurring foods. In: Mountford, CP (Ed) Records of the American-Australian Scientific Expedition to Arnhem Land. Vol. 2.Anthropology and Nutrition. Melbourne University Press, Melbourne, Australia 90-135.

McArthur, M (1960b) Food consumption and dietary levels of the Aborigines at the settlements. In: Mountford, CP (Ed) Records of the American-Australian Scientific Expedition to Arnhem Land. Vol. 2. Anthropology and Nutrition. Melbourne University Press, Melbourne, Australia 14-26.

McArthur, M, Billington, BP \& Hodges, KJ (2000a) Nutrition and health (1948) of Aborigines in settlements in Arnhem Land, northern 
Australia. Overview written by R. L. Specht. Asia Pacific Journal of Clinical Nutrition, 9, 164-214.

McArthur, M, McCarthy, FD \& Specht, RL (2000b) Nutritional studies (1948) of nomadic Aborigines in Arnhem Land, northern Australia. Asia Pacific Journal of Clinical Nutrition, 9, 215-23.

McCarthy, FD (1954) Buffalo hunting in Arnhem Land. Australian Museum Magazine 11, 252-6.

McCarthy, FD (1957) Australia's Aborigines. Their Life and Culture. A Colorgravure Publication, (The Herald and Weekly Times Ltd.), The Griffin Press, Adelaide, Australia.

McCarthy, FD (1960a) The cave paintings of Groote Eylandt and Chasm Island. In: Mountford, CP (Ed) Records of the American-Australian Scientific Expedition to Arnhem Land. Vol. 2. Anthropology and Nutrition. Melbourne University Press, Melbourne, Australia 297414.

McCarthy, FD (1960b) The string figures of Yirrkala. In: Mountford, CP (Ed) Records of the American-Australian Scientific Expedition to Arnhem Land. Vol. 2. Anthropology and Nutrition. Melbourne University Press, Melbourne, Australia 415-511.

McCarthy, FD \& Setzler, FM (1960) The archaeology of Arnhem Land. In: Mountford, CP (Ed) Records of the American-Australian Scientific Expedition to Arnhem Land. Vol. 2. Anthropology and Nutrition. Melbourne University Press, Melbourne, Australia 215-96.

McCarthy, L (2011) Ecology and the Arnhem Land Expedition: Raymond Specht, a botanist in the field. In: Thomas, M \& Neale, M (Eds) Exploring the Legacy of the 1948 Arnhem Land Expedition. Australian National University E Press, Canberra, Australia 15769.

McCarthy, FD \& McArthur, M (1960). The food quest and the time factor in Aboriginal economic life. In Mountford, $\mathrm{CP}(\mathrm{Ed})$ Records of the American-Australian Scientific Expedition to Arnhem Land. Vol. 2. Anthropology and Nutrition. Melbourne University Press, Melbourne, Australia 145-94.

McGregor, JF \& Newcombe, HB (1972) Dose-response relationships for yields of major eye malformations following low doses of radiation in trout sperm. Radiation Research, 49, 155-69.

McIntosh, IS (2011) Missing the Revolution! Negotiating disclosure on the pre-Macassans (Bayini) in North-East Arnhem Land. In: Thomas, M \& Neale, M (Eds) Exploring the Legacy of the 1948 Arnhem Land Expedition. Australian National University E Press, Canberra, Australia 337-54.

McKenzie, R (2011) The String Figures of Yirrkala: Examination of a legacy. In: Thomas, $M$ \& Neale, M (Eds) Exploring the Legacy of the 1948 Arnhem Land Expedition. Australian National University E Press, Canberra, Australia 191-212.

McMillan, A (2001) An Intruder's Guide to East Arnhem Land. Duffy \& Snellgrove, Potts Point, New South Wales, Australia. (Distributed by Pan Macmillan)

Meehan, B \& White, N (Eds) (1990) Hunter-gatherer Demography: Past and Present. University of Sydney Press, Sydney, Australia.

Melville, R \& Specht, RL (1974) Relict species that have retained primitive morphological characters. In: Specht, RL, Roe, EM \& Boughton, VH (Eds) Conservation of Major Plant Communities in Australia and Pариа New Guinea. Australian Journal of Botany Supplementary Series No. 7, Melbourne, Australia 615-28.

Miller, GH \& Cashner, RC (2011) Beneath the Billabongs: The scientific legacy of Robert Rush Miller. In: Thomas, M \& Neale, M (Eds) Exploring the Legacy of the 1948 Arnhem Land Expedition. Australian National University E Press, Canberra, Australia 27182.

Miller, PC (Ed.) (1981) Resource Use by Chaparral and Matorral. Springer-Verlag, New York, U.S.A.

Miller, RR (1998) Reflections of an ichthyologist. In: Specht, RL \& Specht, A (Eds) Personal Experiences on the 'Coast of Adventure'. Arnhem Land Reunion, Sydney, $27^{\text {th }}-28^{\text {th }}$ June 1998. Southern Cross University, Lismore, New South Wales, Australia 34-35.

Mitchell, FJ (1955) Preliminary account of the Reptilia and Amphibia collected by the National Geographic Society - Commonwealth Government - Smithsonian Institution Expedition to Arnhem Land (April to November 1948). Records of the South Australian Museum, 11, 373-408.

Mitchell, FJ (1964) Reptiles and amphibians of Arnhem Land. In: Specht, RL (Ed) Records of the American-Australian Scientific Expedition to Arnhem Land. Vol. 4. Zoology. Melbourne University Press, Melbourne, Australia 309-44.
Mittelheuser, CJ (1977) Rapid ultrastructural recovery of water stressed leaf tissue. Zeitschrift für Pflanzenphysiologie, 82, 458-61.

Monteith, JL (1958) The heat balance of soil beneath crops. UNESCO Arid Zone Research, 11, 123-8.

Monteith, JL (1973) Principles of Environmental Physics. Edward Arnold, London, England.

Moody, JEH (1960) The dental and periodontal conditions of Aborigines at settlements in Arnhem Land and adjacent areas. In: Mountford, CP (Ed) Records of the American-Australian Scientific Expedition to Arnhem Land. Vol. 2. Anthropology and Nutrition. Melbourne University Press, Melbourne, Australia 60-71.

Moody, JEH (1998) Experiences of the 'Flying Dentist'. In: Specht, RL \& Specht, A (Eds) Personal Experiences on the 'Coast of Adventure'. Arnhem Land Reunion, Sydney, 27-28 $8^{\text {th }}$ June 1998. Southern Cross University, Lismore, New South Wales, Australia.

Mountford, CP (Jan. 1946) Earth's Most Primitive People. National Geographic Magazine, 89, 41-42, 89-112.

Mountford, CP (1948) Brown Men and Red Sands. Wanderings in Wild Australia. Robertson \& Mullens Ltd, Melbourne, Australia.

Mountford, CP (with photographs by Howell Walker) (Dec. 1949) Exploring Stone Age Arnhem Land. National Geographic Magazine, 96, 745-82.

Mountford, CP (1954) Australia: Aboriginal Paintings - Arnhem Land. UNESCO World Art Series No. 3.

Mountford, CP (Ed.) (1956) Records of the American-Australian Scientific Expedition to Arnhem Land. Vol. 1. Art, Myth and Symbolism. Melbourne University Press, Melbourne, Australia.

Mountford, CP (1958) The Tiwi: Their Art, Myths and Ceremony. Phoenix House, London, England.

Mountford, CP (Ed.) (1960) Records of the American-Australian Scientific Expedition to Arnhem Land. Vol. 2. Anthropology and Nutrition. Melbourne University Press, Melbourne, Australia.

Neale, M (2011) Epilogue: Sifting the silence. In: Thomas, M \& Neale, M (Eds) Exploring the Legacy of the 1948 Arnhem Land Expedition. Australian National University E Press, Canberra, Australia 42336.

Nicholson, PH (1981) Fire and the Australian Aborigine - an enigma. In: Gill, AM, Groves, RH\& Noble, IR (Eds) Fire and the Australian Biota. Australian Academy of Science, Canberra, Australia, Australia 55-76.

Noble, JC \& Bradstock, RA (Eds) (1989) Mediterranean Landscapes in Australia. Mallee Ecosystems and Their Management. CSIRO (Aust.) Publishing, Melbourne, Australia.

Ophel, IL\& Hoppenheit, M, with assistance of R Ichikawa, P Metalli, Y Nishiwaki, M Saiki \& WL Templeton (1976) Effects of ionizing radiation on aquatic organisms. Report on the Panel on the Effects of Ionizing Radiation on Aquatic Organisms and Ecosystems. Part II. International Atomic Energy Agency, Vienna, Austria.

Oppenheimer, S (2003) Out of Africa's Eden - The Peopling of the World. Jonathon Ball, London, England.

Ozanne, PG \& Specht, RL (1981) Mineral nutrition of heathlands. Phosphorus toxicity. In: Specht, RL (Ed) Ecosystems of the World. Vol. 9b. Heathlands and Related Shrublands. Analytical Studies. Elsevier, Amsterdam, The Netherlands 209-13.

Parker, KW \& Martin, SC (1952) The Mesquite Problem on Southern Arizona Ranges. United States Department of Agriculture Circular, No. 908.

Pearn, JH (2001) A Doctor in the Garden. Amphion Press, Brisbane, Australia.

Pearn, JH (Sept. 2004) Medical Ethnobotany of Australia. Past and Present. Paper presented to the Linnean Society, London, England.

Pianka, ER \& Schall, JJ (1981) Species densities of Australian vertebrates. In: Keast, A (Ed) Ecological Biogeography of Australia. Junk, The Hague, The Netherlands 1675-94.

Pizzy, G (1980) A Field Guide to the Birds of Australia. Collins, Sydney, Australia.

Prescott, GW \& Scott, AM (1952) Some South Australian desmids. Transactions of the Royal Society of South Australia, 75, 55-69.

Prescott, JA (1938) The climate of tropical Australia in relation to possible agricultural occupation. Transactions of the Royal Society of South Australia, 62, 229-40.

Prescott. JA (1949) A climatic index for the leaching factor in soil formation. Journal of Soil Science, 1, 9-19.

Prescott, JA \& Pendleton, RL (1952) Laterite and Lateritic Soils. Commonwealth Bureau of Soil Science \& Technology Communication No. 47. 
Prescott, JA \& Thomas, JA (1948) The length of the growing season in Australia as determined by the effectiveness of the rainfall. A revision. Proceedings of the Royal Geographical Society of Australia, South Australian Branch, 50, 42-6.

Prescott, JA, Collins, JA \& Shirpurkar, GR (1952) The comparative climatology of Australia and Argentina. Geographical Review, 42, 118-33.

Purdie, RW (1987) Selection of key area networks for regional nature conservation-the revised Bolton and Specht Method. Proceedings of the Royal Society of Queensland, 97, 59-71.

Reid, J (1983) Sorcerers and Healing: Continuity and Change in an Aboriginal Medical System. Australian National University Press, Canberra, Australia.

Roberts, RG, Jones, R \& Smith, MA (1990) Thermoluminescence dating of a 50,000-year-old human occupation site in northern Australia. Nature, 345, 153-6.

Roberts, RG, Jones, R \& Smith, MA (1994a) Beyond the radiocarbon barrier in Australian prehistory. Antiquity, 68, 611-6.

Roberts, RG, Jones, R, Spooner, NA, Head, MJ, Murray, AS \& Smith, MA (1994b) The human colonization of Australia: Optical dates of 53,000 and 60,000 years bracket human arrival at Deaf Adder Gorge, Northern Territory. Quaternary Geochronology(Quaternary Science Reviews), 13, 575-83.

Roberts, RG, Bird, M, Olley, J, Galbraith, R, Lawson, E, Laslett, G, Yoshida, H, Jones, R, Fullagar, R, Jacobsen, G \& Huan, Q (1998) Optical and radiocarbon dating at Jinmium rock shelter in northern Australia. Nature, 393, 358.

Rodin, L (Ed.) (1972) Eco-physiological Foundation of Ecosystem Productivity in the Arid Zone. Publishing House 'Nauka', Leningrad, U.S.S.R.

Rogers, RW \& Stevens, GN (1981) Lichens. In: Keast, A (Ed) Ecological Biogeography of Australia. Junk, The Hague, The Netherlands 591-603.

Roth, WE (1897) Ethnological Studies among the North-West-Central Queensland Aborigines. Government Printer, Brisbane, Australia.

Roy, J, Aronson, J \& di Castri, F (Eds) (1995) Time Scales of Biological Responses to Water Constraints. The Case of Mediterranean Biota. SPB Academic Publishing, Amsterdam, The Netherland.

Russell-Smith, J (1991) Classification, species richness and environmental relations of monsoonal rainforest in northern Australia. Journal of Vegetation Science, 2, 259-78.

Russell-Smith, J, Whitehead, P \& Cooke, P (Eds) (2009) Culture, Ecology and Economy of Fire Management in North Australian Savannas. Rekindling the Wurrk Tradition. CSIRO Publishing, Melbourne, Australia.

Saenger, P, Specht, MM, Specht, RL \& Chapman, VJ (1977) Mangal and coastal salt-marsh communities in Australasia. In: Chapman, VJ (Ed) Ecosystems of the World. Vol. 1. Wet Coastal Ecosystems. Elsevier, Amsterdam, The Netherlands 293-345.

Scarlett, NH (1982) Bush medicines: The pharmacopoeia of the Yolngu of Arnhem Land. In: Reid, J \& White, N (Eds) Body, Land and Spirit: Health and Healing in Aboriginal Society. University of Queensland Press, St Lucia, Queensland, Australia.

Schulmeister, J (1992) A Holocene pollen record from lowland tropical Australia. The Holocene, 2, 107-16, 154-191.

Schulmeister, J \& Lees, BG (1995) Pollen evidence from tropical Australia for the onset of an ENSO-dominated climate at c. $4000 \mathrm{BP}$. The Holocene, 5, 10-18.

Scott, AM \& Prescott, GW (1958) Some freshwater algae from Arnhem Land in the Northern Territory of Australia. In: Specht, RL \& Mountford, CP (Eds) Records of the American-Australian Scientific Expedition to Arnhem Land. Vol. 3. Botany and Plant Ecology. Melbourne University Press, Melbourne, Australia 9-136.

Setzler, FM \& McCarthy, FD (1950) A unique archeological specimen from Australia. Journal of the Washington Academy of Sciences, 40, 1-5.

Simpson, C (1951) Adam in Ochre. Angus \& Robertson, Sydney, Australia.

SLATS (1991-2010) Land Cover Changes in Queensland 1991-1995, 19951997, 1997-1999, 1999-2001, 2003-2004, 2008-09. A Statewide Landcover and Trees Study (SLATS). Queensland Department of Environment and Resource Management, Brisbane, Australia. Website: www.derm.qld.gov.au/slats

Smith, AG \& Briden, JC (1977) Mesozoic and Caenozoic Palaeocontinental Maps. Cambridge University Press, Cambridge, England.

Smyth, D \& von Sturmer, J (1981) The Use of Plants by the Aboriginal People in the Oenpelli Region of Western Arnhem Land. Australian Institute of Aboriginal Studies, Canberra, Australia. (Unpublished)
Specht, MM (1964) The history of zoological collections made in and on the shores of the Arnhem Land Aboriginal Reserve. In: Specht, RL (Ed) Records of the American-Australian Scientific Expedition to Arnhem Land. Vol. 4. Zoology. Melbourne University Press, Melbourne, Australia 1-7.

Specht, MM \& Specht, RL (1962) Bibliographia Phytosociologica; Australia. Excerpta Botanica, Section B, 4, 1-58.

Specht, RL (1972a). Water use by perennial, evergreen plant communities in Australia and Papua New Guinea. Australian Journal of Botany 17, 273-99.

Specht, RL (1957a) Dark Island heath (Ninety-Mile Plain, South Australia). 4. Soil moisture patterns produced by rainfall interception and stem flow. Australian Journal of Botany, 5, 137-50.

Specht, RL (1957b) Dark Island heath (Ninety-Mile Plain, South Australia). 5. The water relationships in heath vegetation and pastures on the Makin Sand. Australian Journal of Botany, 5, 151-72.

Specht, RL (1958a) Climate, geology, soils and plant ecology of the northern portion of Arnhem Land. In: Specht, RL \& Mountford, CP (Eds) Records of the American-Australian Scientific Expedition to Arnhem Land. Vol. 3. Botany and Plant Ecology. Melbourne University Press, Melbourne, Australia 333-414.

Specht, RL (1958b) Geographical relationships of the flora of Arnhem Land. In: Specht, RL \& Mountford, CP (Eds) Records of the American-Australian Scientific Expedition to Arnhem Land. Vol. 3. Botany and Plant Ecology. Melbourne University Press, Melbourne, Australia 415-478.

Specht, RL (1958c) An introduction to the ethno-botany of Arnhem Land. In: Specht, RL \& Mountford, CP (Eds) Records of the AmericanAustralian Scientific Expedition to Arnhem Land. Vol. 3. Botany and Plant Ecology. Melbourne University Press, Melbourne, Australia 479-503.

Specht, RL (1958d) Micro-environment (soil) of a natural plant community. In: Climatology and Microclimatology. Proceedings of the Canberra Symposium. Arid Zone Research Vol. XI, UNESCO, Paris, France 152-55.

Specht, RL (1958e) Range management in the arid zone of the United States. Arid Zone Newsletter, 1958, 75-8.

Specht, RL (1958f) The history of botanical exploration in the Arnhem Land Aboriginal Reserve. In: Specht, RL \& Mountford, CP (Eds) Records of the American-Australian Scientific Expedition to Arnhem Land. Vol. 3. Botany and Plant Ecology. Melbourne University Press, Melbourne, Australia 1-7.

Specht, RL (1958g) The Gymnospermae and Angiospermae collected on the Arnhem Land Expedition. In: Specht, RL \& Mountford, CP (Eds) Records of the American-Australian Scientific Expedition to Arnhem Land. Vol. 3. Botany and Plant Ecology. Melbourne University Press, Melbourne, Australia 185-318.

Specht, RL (1963) Dark Island heath (Ninety-Mile Plain, South Australia). 7. The effect of fertilizers on composition and growth, 1950-60. Australian Journal of Botany, 11, 67-94.

Specht, RL (Ed.) (1964) Records of the American-Australian Scientific Expedition to Arnhem Land. Vol. 4. Zoology. Melbourne University Press, Melbourne, Australia.

Specht, RL (1967) The photosynthesis of plant communities in relation to structure, physiology and environment. Photosynthetica, 1, 132-34.

Specht, RL (1969) A comparison of the sclerophyllous vegetation characteristic of Mediterranean-type climates in France, California and southern Australia. 1. Structure, morphology and succession. 2. Dry matter, energy and nutrient accumulation. Australian Journal of Botany, 17, 277-92, 293-308.

Specht, RL (1970) Vegetation. In Leeper, GW (Ed) The Australian Environment. Fourth Edition. CSIRO \& Melbourne University Press, Melbourne, Australia 44-67.

Specht, RL (1972b) Water use by plant communities in the arid zone of Australia. In: Rodin, LE (Ed.) Eco-physiological Foundation of Ecosystem Productivity in the Arid Zone. Publishing House 'Nauka', Leningrad, U.S.S.R 48-53.

Specht, RL (Ed) (1973a) American-Australian Scientific Expedition to Arnhem Land, March-November 1948. Song Book. Arnhem Land Expedition Reunion, Sydney, 10-11 ${ }^{\text {th }}$ March 1973. Botany Department, University of Queensland, Brisbane, Australia.

Specht, RL (1973b) Structure and functional response of ecosystems in the Mediterranean climate of Australia. In: di Castri, F \& Mooney, HA (Eds) Mediterranean Type Ecosystems: Origin and Structure. Springer-Verlag, New York, U.S.A 113-20 
Specht, RL (June 1976) The Arnhem Land Escarpment - A National Monument. Ranger Uranium Environmental Inquiry, Submission June 1976, Sydney, Australia.

Specht, RL (1981a) Major vegetation formations in Australia. In: Keast, A (Ed) Ecological Biogeography of Australia. Junk, The Hague, The Netherlands 163-298.

Specht, RL (1981b) Structural attributes - foliage projective cover and standing biomass. In: Gillison, AN \& Anderson, DJ (Eds) Vegetation Classification in the Australian Region. CSIRO \& Australian National University Press, Canberra, Australia 10-21.

Specht, RL (1981c) Growth indices - Their role in understanding the growth, structure and distribution of Australian vegetation. Oecologia, 50, 347-56.

Specht, RL (1981d) Biogeography of halophytic angiosperms (salt-marsh, mangrove, sea-grass). In: Keast, A (Ed) Ecological Biogeography of Australia. Junk, The Hague, The Netherlands 575-90.

Specht, RL (1981e) Ecophysiological principles determining the biogeography of major vegetation formations in Australia. In: Keast, A (Ed) Ecological Biogeography of Australia. Junk, The Hague, The Netherlands 299-322.

Specht, RL (1988a) Origin and evolution of terrestrial plant communities in the wet-dry tropics of Australia. Proceedings of the Ecological Society of Australia, 15, 19-30.

Specht, RL (Ed.) (1988b) Mediterranean-type Ecosystems. A Data Source Book. Tasks for Vegetation Science. Vol. 19. Kluwer Academic Publishers, Dordrecht, The Netherlands.

Specht, RL (1988c) Climatic control of ecomorphological characters and species richness in mediterranean-type ecosystems. In: Specht, RL (Ed) Mediterranean-type Ecosystems. A Data Source Book. Kluwer Academic Publishers, Dordrecht, The Netherlands 149-55.

Specht, RL (1990) Forested wetlands in Australia. In: Lugo, AE, Brinson, MM \& Brown, S (Eds) Ecosystems of the World. Vol. 16. Wetland Forests. Elsevier, Amsterdam, The Netherlands 387-406.

Specht, RL (1997) Ecosystem dynamics in coastal dunes of eastern Australia. In: van der Maarel, E (Ed) Ecosystems of the World. Vol. 2C. Dry Coastal Ecosystems. General Aspects. Elsevier, Amsterdam, The Netherlands 483-95.

Specht, RL (1998a) Northward Bound!. In: Specht, RL \& Specht, A (Eds) Personal Experiences on the 'Coast of Adventure'. Arnhem Land Reunion, Sydney, $27^{\text {th }}-28^{\text {th }}$ June 1998 . Southern Cross University, Lismore, New South Wales, Australia. (Reprinted from Adelaide Teachers' College Magazine, December 1946) 14.

Specht, RL (1998b) Field Work, 5.1. Experiences of the botanist. 5.2. Hazards of field work. In: Specht, RL \& Specht, A (Eds) Personal Experiences on the 'Coast of Adventure'. Arnhem Land Reunion, Sydney, $27^{\text {th }}-28^{\text {th }}$ June 1998. Southern Cross University, Lismore, New South Wales, Australia 23-27, 28-30.

Specht, RL (2002) Obituary. Margaret McArthur Oliver 1919-2002. Australian Aboriginal Studies, 2002/2, 122-4.

Specht, RL (2004) Obituary. Brian Price Billington 24 February 1923 - 6 August 2004. Australian Aboriginal Studies, 2004/2, 133.

Specht, RL (2006) Aboriginal plant names in north-eastern Arnhem Land. Groote Eylandt - Enindilyakwa language; Yirrkala - Rirratjingu language. Australian Aboriginal Studies, 2006, 63-7.

Specht, RL (2011) Development of ecosystem research. International Scholarly Research Network, ISRN Ecology, Volume 2011, Article ID 897578, 20 pages. (doi:10.5402/2011/897578)

Specht, RL (2012) Biodiversity of terrestrial ecosystems in tropical to temperate Australia. International Journal of Ecology, Volume 2012, Article ID 359892, 15 pages.(doi: 10.1155/2012/359892)

Specht, RL \& Dettmann, ME (1995) Palaeo-ecology of Australia and current physiological functioning of plant communities.. In: Roy, J, Aronson, J \& di Castri, F (Eds) Time Scales of Biological Responses to Water Constraints: The Case of Mediterranean Biota. SPB Academic Publishing, Amsterdam, The Netherlands 201-14

Specht, RL \& Groves, RH (1966) A comparison of the phosphorus nutrition of Australian heath plants and introduced economic plants. Australian Journal of Botany, 14, 201-21.

Specht, RL \& Jones, R (1971) A comparison of the water use by heath vegetation at Frankston, Victoria, and Dark Island Soak, South Australia. Australian Journal of Botany, 19, 311-26.

Specht, RL \& McCarthy FD (2005) The 'Snake Woman Story' of Hemple Bay, Groote Eylandt: An Enindilyakwa legend of a tsunami in the Gulf of Carpentaria. Proceedings of the Royal Society of Queensland, 112, 77-82.
Specht, RL \& Mountford, CP (Eds) (1958) Records of the AmericanAustralian Scientific Expedition to Arnhem Land. Vol. 3. Botany and Plant Ecology. Melbourne University Press, Melbourne, Australia.

Specht, RL \& Perry, RA (1948) Plant ecology of part of the Mount Lofty Ranges. Transactions of the Royal Society of South Australia, 72, 91-132.

Specht, RL \& Rundel, PW (1990) Sclerophylly and foliar nutrient status of Mediterranean-climate plant communities in southern Australia. Australian Journal of Botany, 38, 459-74.

Specht, RL \& Specht, A (1989a) Canopy structure in Eucalyptus-dominated communities in Australia along climatic gradients. Acta Oecologia, Oecologia Plantarum, 10, 191-202.

Specht, RL \& Specht, A (1989b) Species richness of overstorey strata in Australian plant communities - The influence of overstorey growth rates. Australian Journal of Botany, 37, 321-36.

Specht, RL \& Specht, A (1989c) Species richness of sclerophyll (heathy) plant communities in Australia. The influence of overstorey cover. Australian Journal of Botany, 37, 337-50.

Specht, RL \& Specht, A (1995) Global warming: Predicted effects on structure and species richness of Mediterranean ecosystems in southern Australia. In: Roy, J, Aronson, J \& di Castri, F (Eds) Time Scales of Biological Responses to Water Constraints: The Case of Mediterranean Biota. SPB Academic Publishing, Amsterdam, The Netherlands 215-37.

Specht, RL \& Specht, A (Eds) (1998) American-Australian Scientific Expedition to Arnhem Land, March -November 1948. Personal Experiences on the 'Coast of Adventure'. Arnhem Land Expedition Reunion, Sydney, 27-28 ${ }^{\text {th }}$ June 1998. Southern Cross University, Lismore, New South Wales, Australia.

Specht, RL \& Specht, A (1999) Australian Plant Communities. Dynamics of Structure, Growth and Biodiversity. Oxford University Press, Melbourne, Australia. (Paperback 2002)

Specht, RL \& Tyler, MJ (2010) The species richness of vascular plants and amphibia in major plant communities in temperate and tropical Australia: relationship with annual biomass production. International Journal of Ecology, Volume 2010, Article ID 635852, 17 pages. (doi;10.1155/2010/635852)

Specht, RL, Rayson, P \& Jackman, ME (1958) Dark Island heath (NinetyMile Plain, South Australia). 6. Pyric succession: Changes in composition, coverage, dry weight, and mineral nutrient status. Australian Journal of Botany, 6, 59-88.

Specht, RL, Roe, EM \& Boughton, VH (Eds) (1974a) Conservation of Major Plant Communities in Australia and Papua New Guinea. Australian Journal of Botany Supplement No. 7, Melbourne, Australia.

Specht, RL, with the assistance of Blake, ST, Briggs, BG, Burbidge, NT, Clifford, HT, Hoogland, R, Johnson, LAS, Melville, R, and Schodde, R. (1974b) Relict species that have retained floral characters generally accepted by taxonomists and morphologists as primitive. In: Specht, RL, Roe, EM \& Boughton, VH (Eds) Conservation of Major Plant Communities in Australia and Papua New Guinea. Australian Journal of Botany Supplementary Series No. 7, Melbourne, Australia 606-15.

Specht, RL, Salt, RB \& Reynolds, S (1977) Vegetation in the vicinity of Weipa, North Queensland. Proceedings of the Royal Society of Queensland, 88, 17-38.

Specht, RL, Rogers, RW \& Hopkins, AJM (1981) Seasonal growth and flowering rhythms: Australian heathlands. In: Specht, RL (Ed.)Ecosystems of the World. Vol. 9B. Heathlands and Related Shrublands. Analytical Studies. Elsevier, Amsterdam, The Netherlands 5-13.

Specht, RL, Moll, EJ, Pressinger, F \& Sommerville, J (1983) Moisture regime and nutrient control of seasonal growth in mediterranean ecosystems. In: Kruger, FJ, Mitchell, DT \& Jarvis, JUM (Eds) Mediterranean-Type Ecosystems. The Role of Nutrients. SpringerVerlag, Berlin, Germany 120-32.

Specht, RL, Grundy, RI \& Specht, A (with Berliner, R) (1990) Species richness of plant communities - relationship with community growth and structure. Israel Journal of Botany, 39, 465-80.

Specht, RL, Yates, DJ, Sommerville, JEM \& Moll, EJ (1991) Foliage structure and shoot growth in heathlands in the mediterranean-type climate of southern Australia and South Africa. Ecologia Mediterranea, 16, 195-207. 
Specht, RL, Specht, A, Whelan, MB \& Hegarty EE (1995) Conservation Atlas of Plant Communities in Australia. Southern Cross University, Lismore, New South Wales, Australia.

Specht, RL, Batianoff, GN \& Reeves, RD (2006) Vegetation structure and biodiversity along the eucalypt forest to rainforest continuum on the serpentinite soil catena in a subhumid area of Central Queensland, Australia. Austral Ecology, 32, 394-407.

Specht, RL, Nurcombe, B \& Robertson, DJ (2013) Assessment of mental health in Indigenous Australians - John Ewart Cawte (1925-2011). Australian Aboriginal Studies (submitted).

Stewart, GR, Gracia, CA, Hegarty, EE \& Specht, RL (1990) Nitrate reductase activity and chlorophyll content in sun leaves of subtropical Australian closed-forest (rainforest) and open-forest communities. Oecologia, 82, 544-51.

Stocker, GC (1966) Effects of fire on vegetation in the Northern Territory. Australian Forestry, 30, 223-30.

Stocker, GC (1971) The age of charcoal from old jungle fowl nests and vegetation change on Melville Island. Search, 2, 28-30.

Taylor, P (1989) The Genus Utricularia - A taxonomic monograph. Her Majesty's Stationary Office, London, England.

Taylor, WR (1964) Fishes of Arnhem Land. In: Specht, RL (Ed) Records of the American-Australian Scientific Expedition to Arnhem Land. Vol. 4. Zoology. Melbourne University Press, Melbourne, Australia 45-308.

Thomas, M (2007) Taking Them Back. Archival Media in Arnhem Land Today. Cultural Studies Review, 13, 20-37.

Thomas, M (2010) A short history of the 1948 Arnhem Land Expedition. Aboriginal History, 34, 143-70.

Thomas, M (2011a) Expedition as a time capsule: Introducing the American-Australian Scientific Expedition to Arnhem Land. In: Thomas, M \& Neale, M (Eds) Exploring the Legacy of the 1948 Arnhem Land Expedition. Australian National University E Press, Canberra, Australia 1-30.

Thomas, M (2011b) Unpacking the Testimony of Gerald Blitner: Crosscultural brockerage and the Arnhem Land Expedition. In: Thomas, M \& Neale, M (Eds) Exploring the Legacy of the 1948 Arnhem Land Expedition. Australian National University E Press, Canberra, Australia 377-401.

Thomas, M \& Neale, M (Eds) (2011) Exploring the Legacy of the 1948 Arnhem Land Expedition. Australian National University E Press, Canberra, Australia. Online at: http://epress.anu.edu.au/arnhem_citation.html

Thomson, D (1998) Donald Thomson in Arnhem Land. In: Specht, RL \& Specht, A (Eds) Personal Experiences on the 'Coast of Adventure'. Arnhem Land Reunion, Sydney, $27^{\text {th }}-28^{\text {th }}$ June 1998. Southern Cross University, Lismore, New South Wales, Australia. pp. 52-53.

Thomson, DF (1939) The seasonal factor in human culture. Proceedings of the Prehistory Society, 10, London, England.

Thomson, DF (August 1946) The story of Arnhem Land. Walkabout, August 1946, 5-22.

Thomson, DF (March 1948) An Arnhem Land Adventure. National Geographic Magazine, 93, 403-30.

Thomson, DF (1983) Donald Thomson in Arnhem Land. Currey O'Neil, South Yarra, Victoria, Australia.

Thomson, DF (2003) Donald Thomson in Arnhem Land. (Ed. N Peterson) The Miegunyah Press, Melbourne University Publishing Ltd., Melbourne, Australia.

Thornthwaite, CW (1948) An approach toward a rational classification of climate. Geographical Review, 38, 55-94.

Thornthwaite, CW (1958). Introduction to arid zone climatology. In: Climatology and Microclimatology. Proceedings of the Canberra Symposium. Arid Zone Research Vol. XI, UNESCO, Paris, France $15-22$.

Tindale, MD (1958) The Pteridophyta of Arnhem Land. In: Specht, RL \& Mountford, CP (Eds) Records of the American-Australian Scientific Expedition to Arnhem Land. Vol. 3. Botany and Plant Ecology. Melbourne University Press, Melbourne, Australia 171-84.

Tindale, NB (1925-26) Natives of Groote Eylandt and the west coast of the Gulf of Carpentaria. Parts 1 and 2. Records of the South Australian Museum, 3, 61-102, 103-34.

Tiver, NS \& Crocker, RL (1951) The grasslands of south-eastern South Australia in relation to climate, soils, and developmental history. Journal of the British Grassland Society, 6, 29-80.

Trotter, M, Duggins, OH \& Setzler, FM (1960) Hair of Australian Aborigines. In: Records of the American-Australian Scientific Expedition to Arnhem Land. Vol. 2.Anthropology and Nutrition.
(Ed. C. P. Mountford). Melbourne University Press, Melbourne, Australia 195-202.

Truswell, EM (1982) Palynology of a Tertiary core sample from South Alligator River area, E.L.1287. Bureau of Mineral Resources, Canberra, Australia.

Tyler, MJ \& Davies, M (1986) Frogs of the Northern Territory. Conservation Commission of the Northern Territory, Alice Springs, Australia.

Tyler, MJ, Crook, GA \& Davies, M (1983) Reproductive biology of the frogs of the Magela Creek System, Northern Territory. Records of the South Australian Museum, 18, 415-40.

Tyler, MJ, Davies, M \& Watson, GG (1986) The frog fauna of Groote Eylandt, Northern Territory, Australia. Zoological Journal of the Linnean Society, 88, 91-101.

Tyler, MJ, Davies, M \& Watson, GF (1991) The frog fauna of Melville Island, Northern Territory. The Beagle, 8, 1-10.

UNESCO (1958) Climatology and Microclimatology. Proceedings of the Canberra Symposium. Arid Zone Research Vol. XI, UNESCO, Paris, France.

Wahlqvist, ML \& Specht, RL (1998) Food variety and biodiversity: Econutrition. Asia Pacific Journal of Clinical Nutrition, 7, 314-19.

Walker, H (July 1942) Life in Dauntless Darwin, Australia. National Geographic Magazine, 82, 123-38.

Walker, H (Jan. 1943) American bombers attacking from Australia. National Geographic Magazine, 83, 49-70.

Walker, H (Sept. 1949) Cruise to Stone Age Arnhem Land, Australia. National Geographic Magazine, 96, 417-30.

Walker, H (1998) Experiences with the Aborigines of Arnhem Land. pp. 4647. In: Specht, RL \& Specht, A (Eds) Personal Experiences on the 'Coast of Adventure'. Arnhem Land Reunion, Sydney, $27^{\text {th }}-28^{\text {th }}$ June 1998. Southern Cross University, Lismore, New South Wales, Australia.

Walter, H (1968) Die Vegetation der Erde in öko-physiologischer Betrachtung. Fischer Verlag, Jena, Germany.

Webb, LJ \& Tracey, JG (1975) The Cooloola rain forests. Proceedings of the Australian Ecological Society, 9, 317-21.

Webb, LJ, Tracey, JG \& Williams, WT (1984) A floristic framework of Australian rainforests. Australian Journal of Ecology, 9, 169-98.

White, C (1967a) Plateau and Plain: Prehistoric Investigations in Arnhem Land, Northern Territory. Ph. D. Thesis, Australian National University, Canberra, Australia.

White, C (1967b). Early stone axes in Arnhem Land. Antiquity, 41, 149-52.

White, C (1967c) The prehistory of the Kakadu people. Mankind, 6, 426-31.

White, C (1969) Ethnographic interpretations of the prehistory of western Arnhem Land. Southwestern Journal of Anthropology, 25, 45-67.

White, CT (1949) Additions to the flora of Arnhem Land. Proceedings of the Royal Society of Queensland, 61, 55-8.

Wightman, GM \& Smith, NM (1989) Ethnobotany. Vegetation and Floristics of Milingimbi, Northern Australia. Northern Territory Botanical Bulletin No. 6.

Williams, N (1986) The Yolngu and their Land: A System of Land Tenure and the Fight for its Recognition. Australian Institute of Aboriginal Studies, Canberra, Australia.

Williams, N (1987) Two Laws: Managing Disputes in a Contemporary Aboriginal Community. Australian Institute of Aboriginal Studies, Canberra, Australia.

Wilson, BA, Russell-Smith, J. \& Williams, R. (1996) Terrestrial vegetation. pp. 57-79. In: Finlayson, CM \& von Oertzen, I (Eds) Landscape and Vegetation Ecology of the Kakadu Region. Kluver, Dordrecht, The Netherlands.

Wilson, GDF, Humphrey, CL, Colgan, DJ, Gray, K-A \& Johnson, RN (2009) Monsoon-influenced speciation patterns in a species flock of Eophreatoicus Nicholls (Isopoda: Crustacea). Molecular Phylogenetics and Evolution, 51, 349-64.

Woinarski, JCZ, Hempel, C, Cowie, I, Brennan, K, Kerrigan, R, Leach, G, \& Russell-Smith, J (2006) Distribution patterns of plant species endemic to the Northern Territory, Australia. Australian Journal of Botany, 54, 627-40.

Woinarski, JCZ, Russell-Smith, J, Andersen, AN \& Brennan, K (2009) Fire management and biodiversity of the western Arnhem Land Plateau. In: Russell-Smith, J, Whitehead, P \& Cooke, P (Eds) Culture, Ecology and Economy of Fire Management in North Australian Savannas. Rekindling the Wurrk Tradition. CSIRO Publishing, Melbourne, Australia. pp. 201-227.

Womersley, HBS (1958) Marine algae from Arnhem Land, North Australia. pp. 139-61. In: Specht, RL \& Mountford, CP (Eds) Records of the 
American-Australian Scientific Expedition to Arnhem Land. Vol. 3. Botany and Plant Ecology. Melbourne University Press, Melbourne, Australia.

Wood, RD (1958) Some Characeae from Arnhem Land. p. 137. In: Specht, RL \& Mountford, CP (Eds) Records of the American-Australian Scientific Expedition to Arnhem Land. Vol. 3. Botany and Plant Ecology. Melbourne University Press, Melbourne, Australia.

Worsley, PM (1954) Material Symbols of Human beings among the Wanindiljaugwa. Man, 261, 1-3.

Worsley, PM (1955a) Totemism in a changing society. American Anthropologist, 57, 851-61.
Worsley, PM (1955b) Early Asian contacts with Australia. Past and Present, 7, 1-11.

Worsley, PM (1961) The utilization of food resources by an Australian Aboriginal tribe. Acta Ethnographica. Academiae Scientiarum Hungaricae, 10, 153-90.

Wright, CH (1930) Pandanus basedowii, collected by Dr H Basedow on the Mackay Expedition in Arnhem Land, 1928. Kew Bulletin, 1930.

Yunupingu, B, Marika-Yunupingu,L, Marika, D, Marika, B, Marika B, Marika, R,\& Wightman, G (1995) Rirratjingu Ethnobotany: Aboriginal Plant Use from Yirrkala, Arnhem Land, Australia. Northern Territory Botanical Bulletin No. 21, Darwin, Australia.

(C) Raymond Louis Specht; Licensee Bentham Open.

This is an open access article licensed under the terms of the Creative Commons Attribution Non-Commercial License (http://creativecommons.org/ licenses/by-nc/3.0/), which permits unrestricted, non-commercial use, distribution and reproduction in any medium, provided the work is properly cited. 